$$
\text { UNIVERSIDADE DE SÃO PAULO }
$$

FACULDADE DE FILOSOFIA, LETRAS E CIÊNCIAS HUMANAS

DEPARTAMENTO DE LETRAS CLÁSSICAS E VERNÁCULAS

PROGRAMA DE PÓS-GRADUAÇÃO EM LITERATURA BRASILEIRA

\title{
O tempo das formas em Grande Sertão: Veredas
}

Márcio José Pivotto Barbieri 
UNIVERSIDADE DE SÃO PAULO

FACULDADE DE FILOSOFIA, LETRAS E CIÊNCIAS HUMANAS

DEPARTAMENTO DE LETRAS CLÁSSICAS E VERNÁCULAS

PROGRAMA DE PÓS-GRADUAÇÃO EM LITERATURA BRASILEIRA

\section{O tempo das formas em Grande Sertão: Veredas}

Márcio José Pivotto Barbieri

Dissertação de Mestrado apresentada ao Programa de Pós-Graduação em Literatura Brasileira do Departamento de Letras Clássicas e Vernáculas da Faculdade de Filosofia, Letras e Ciências Humanas da Universidade de São Paulo, para obtenção do título de Mestre em Letras.

Orientador: Prof. Dr. João Adolfo Hansen

São Paulo 
Ao meu avô, José Pivotto.

In memoriam 


\section{AgradeCimentos}

Um trabalho de pesquisa de tanto tempo sempre envolve muitas pessoas e as mais próximas sofrem mais, por isso agradeço especialmente aos meus pais, Ana Maria Pivotto Barbieri e José Ailton Barbieri, por estarem sempre ao meu lado me apoiando; ao meu irmão, André Luis Pivotto Barbieri, que mesmo de longe ajudava no possível; à minha namorada, Naomi Yokoyama Edelbuttel, pelas conversas, leituras do texto e pelo carinho; às minhas avós, dona Luiza Luminatti Pivotto, Aparecida Fim e dona Olga Dias, que rezam por mim.

Além delas, também aos meus amigos que de alguma forma participaram, seja por empréstimo de livros ou ouvidos: Elisabete Marins Ribas, Leonardo Manini, Carol Bispo Rodrigues, Maria José Ciasca, Maria Izabel Soares da Silva, Misael Dias, Daniel Maldonato, Elizabeth Farias e Valeria Pereira.

Aos professores que me ajudaram durante muito tempo: Professora Dra. Betty Salum, que me ensinou a ler um texto de perto; Professor Dr. Paulo Alane Franchetti, pela disponibilidade que apresentou; Professor Dr. Willi Bolle, pelas leituras, comentários e conversas atenciosas.

Especialmente, agradeço ao Professor Dr. Roberto Zular pelas ideias sugeridas na banca de qualificação que nortearam novas pesquisas e também pela participação na banca de defesa; ao Professor Dr. Luiz Roncari, também pela participação e colaboração na banca de qualificação; ao Professor Dr. Antonio Alcir Bernárdez Pécora, pela participação na banca de defesa.

Agradeço muito à Professora Dra. Angélica Chiappetta pelas aulas, conversas, conselhos, leitura dos meus textos e por ter me aceitado como aluno PAE.

Um agradecimento especial e particular ao meu orientador, Professor Dr. João Adolfo Hansen, que topou levar o projeto sobre o tempo adiante e que soube esperar, com muita paciência, os momentos de aprendizado, mesmo que bem tardios. 
Dúvido dez anos. Os pobres ventos no burro da noite.

(Guimarães Rosa. Grande Sertão: Veredas)

0 tempo vê tudo; à tua revelia, 0 tempo te desmascara, denunciando o passado.

(Sófocles. Coro de Édipo Rei) 


\section{SUMÁRIO}

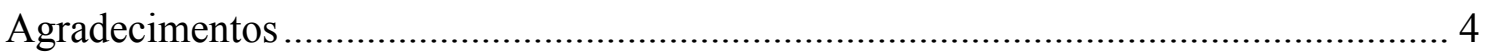

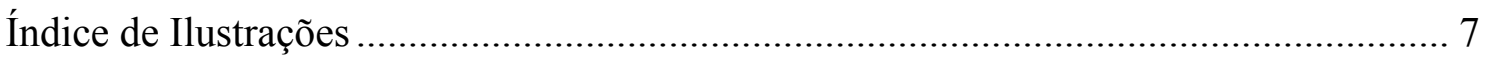

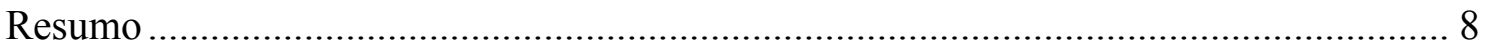

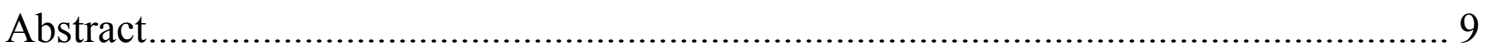

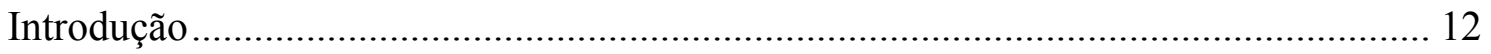

Capítulo 1: Teorias sobre o tempo.......................................................................... 15

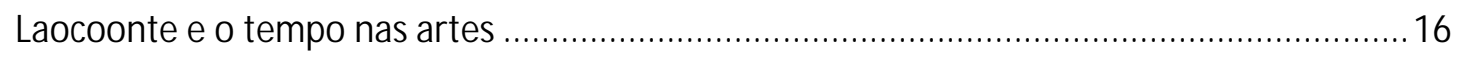

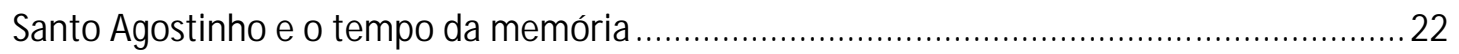

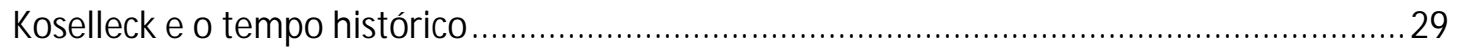

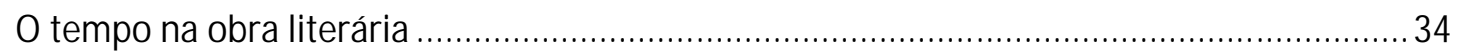

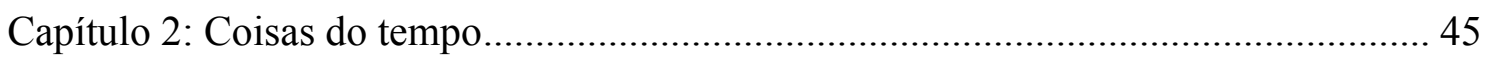

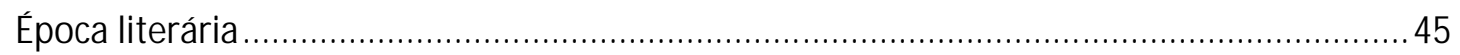

As formas do tempo na obra Grande Sertão: Veredas .....................................................56

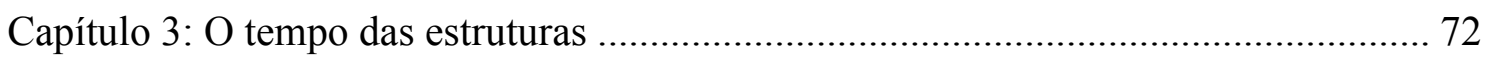

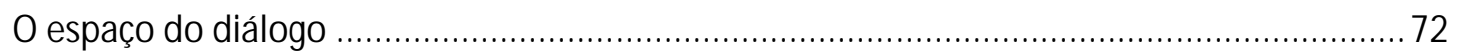

0 ethos do narrador na estrutura da cena do diálogo ......................................................... 83

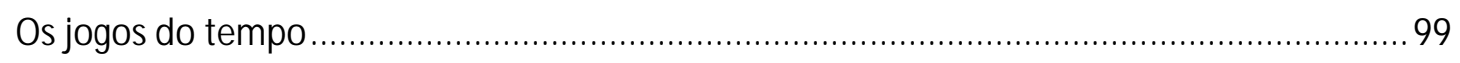

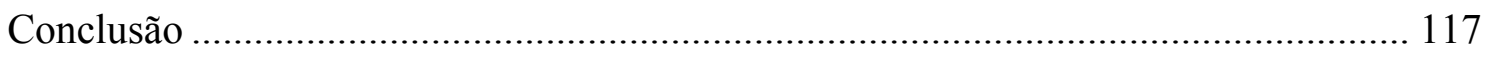

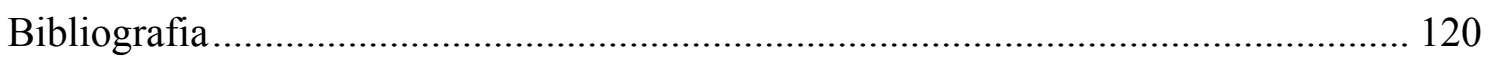

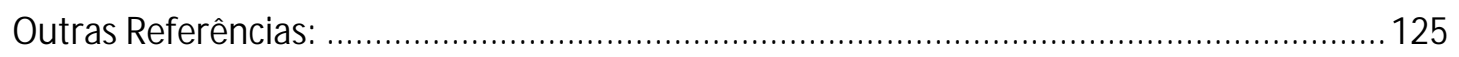




\section{ÍNDICE DE ILUSTRAÇÕES}

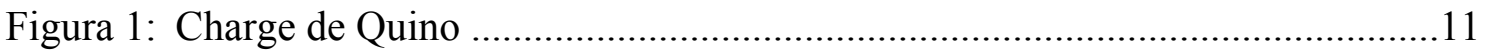

Figura 2: O grupo de Laocoonte, Museu do Vaticano. .................................................. 19

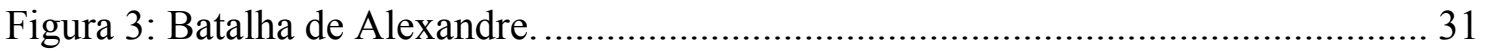




\section{RESUMO}

A presente dissertação propõe-se a analisar o tempo na obra Grande Sertão: Veredas, de João Guimarães Rosa. Inicialmente, apresentam-se algumas teorias sobre o tempo baseadas em textos de Lessing, Santo Agostinho, Koselleck, para chegar às teorias do tempo da narrativa, cujos princípios são retirados principalmente dos ensaios de Benedito Nunes e Mendilow. Fundamentada nessas teorias sobre o tempo, a análise é desenvolvida com o intuito de apresentar as formas de temporalidade no romance de Guimarães Rosa. Assim, situa-se a obra no campo literário brasileiro em que o autor a escreveu. Como consequência, abordam-se algumas referências ao tempo histórico que estão explícitas na fala de Riobaldo, como a passagem da Coluna Prestes pelo Norte e Nordeste brasileiros. Por fim, estudando as descrições de cenas, as imagens criadas a partir do ambiente do sertão, as alegorias a partir de elementos naturais (vento, rio, buritis), pretende-se expor como o tempo aparece em diversos momentos do romance. No último capítulo, desenvolve-se a discussão sobre o tempo das formas, demonstrando-se como a constituição da cena da enunciação põe em jogo categorias do tempo. Parte-se inicialmente da organização da estrutura do romance, a saber, do monólogo em forma de diálogo entre um velho fazendeiro sertanejo e um "doutor" da cidade. Definem-se em seguida os tempos da enunciação (a narração a partir do presente) e do enunciado (os fatos passados da vida do ex-jagunço). Comparando o romance rosiano com dois machadianos (Memórias Póstumas de Brás Cubas e Dom Casmurro), apresentam-se as semelhanças e diferenças entre as formas de constituir as narrativas. Com isso, chega-se à caracterização dos autores fictícios (nas obras de Machado de Assis) e da figura do narrador (no romance de Guimarães Rosa). No final, propõe-se que a organização da primeira parte do romance de Guimarães Rosa, cujo divisor é o episódio do julgamento de Zé Bebelo na fazenda Sempre Verde, é um correlato da elaboração de um devir outro do $e u$ do narrador, que acontece a partir da enunciação. Como a enunciação é definida pelo tempo do presente, o narrador, ao relembrar os fatos de sua vida, projeta outras figuras para o que ele foi (jagunço, atirador e chefe), pois se culpa pelas consequências de suas ações no passado, sendo que a principal é a morte de Diadorim. Essa organização da narração engendra formas de tempo que são os resultados que esta dissertação se propôs a discutir. 


\section{Abstract}

The aim of the dissertation is to analyse time in João Guimarães Rosa's novel Grande Sertão:Veredas. Based on texts of Lessing, St. Augustine and Koselleck, it initially exposes some theories about time to arrive to studies of narrative time whose principles are drawn mainly from essays of Benedito Nunes and Mendilow. Based on these theories about time, the analysis is developed to present the forms of temporality in Guimarães Rosa's novel. Thus, the dissertation inserts the work in Brazilian literary field in which the author wrote it. As a result, it quotes some references of historical time that are explicit in Riobaldo' speech, such as the passage of the Prestes Column through Northern and Northeastern Brazil. By studying the scene descriptions, the images taken from the backlands, the allegories figured by natural elements (wind, river, buritis etc.), the dissertation shows the ways how several species of time appear represented in the novel. The last chapter develops the concept of "time of the forms", demonstrating the ways the set up of the enunciation scene dramatizes categories of time. The chapter starts by the analysis of the organization of the novel's structure, namely, a monologue, as a dialogue between an old farmer of the backlands and a "doctor" (doutor) of the city, in order to define the enunciation's time (the present of narration act) and the story's time (the past actions and facts of the story of bandit (jagunço) Riobaldo's life). Comparing Rosa's novel with two novels written by Machado de Assis (Memórias Póstumas de Brás Cubas and Dom Casmurro), the dissertation studies some similarities and differences that exist between the ways these authors structure their novels. Thus, it characterizes the fictional authors (in Machado de Assis's works) and the figure of the narrator (in Guimarães Rosa's novel). Finally, it concludes that the organization of the first part of Guimarães Rosa's novel - whose turning point is the episode of Zé Bebelo's judgment in the Sempre Verde (Always Green) farm - is an objective correlate of the becoming another of the narrator's identity. Since enunciation is defined by narrator's present time (the narrator tells the facts of his life now), it produces past figures representing what he was (bandit (jagunço), shooter and boss of bands of bandits). The narrator blames himself on account of the consequences of his actions in the past, such as the principal one of them, 
the death of Diadorim. This narrative organization engenders forms of time that are exposed and studied by the dissertation. 


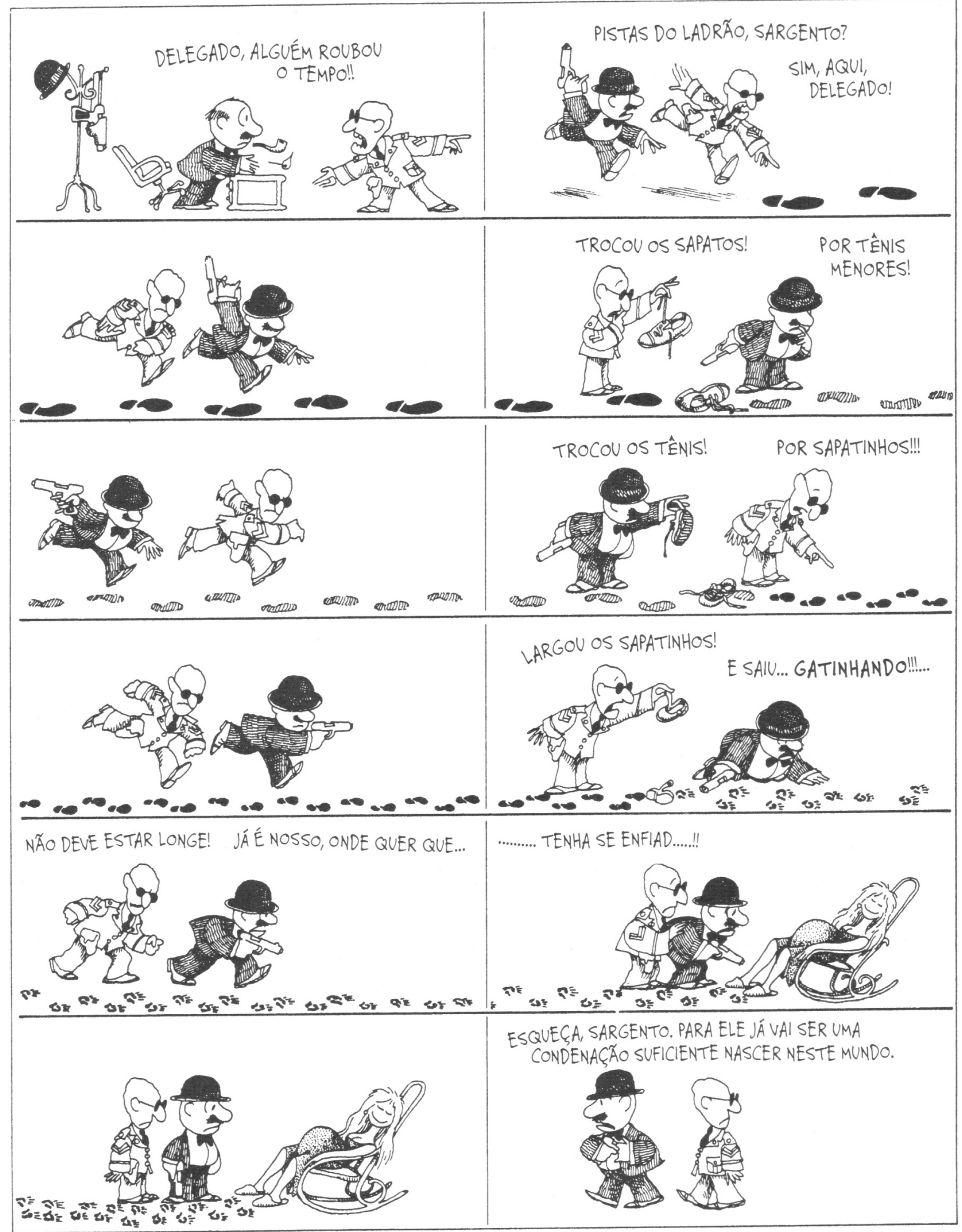




\section{INTRODUÇÃo}

Mas eis aqui o outro perigo e a minha outra compaixão: os pensamentos do que forma parte da população remontam até 0 avô; mas com o avô acaba o tempo.

(Nietzsche. Assim falou Zaratustra)

Depois de propor que o tempo tem um ser, Santo Agostinho deseja saber como fazer para medir sua duração. Para isso, estabelece um lugar para o tempo, que é a mente do homem. O santo católico chega à conclusão, depois de diversas aporias, que se mede o tempo pela distentio animi, ou seja, a distensão da alma. Quando uma pessoa vai declamar um canto de cor (exemplo de Santo Agostinho), ela se prepara para isso. Antes de iniciar, sua alma como que se estende para todo o canto como expectativa do que irá dizer. Assim que começa a fazê-lo, produz o passado com o que já foi declamado (memória) e o futuro com o que espera declamar (expectativa). Assim, o único tempo que realmente existe, conclui Santo Agostinho, é o presente. Com base nisso, o autor define três tipos de presentes: presente do passado, presente do futuro e presente do presente. A cada um desses três presentes, atribui respectivamente a memória, a expectativa e a atenção.

Quando nos deparamos com a charge de Quino, o tempo possui um ser, visto que ele é roubado. A alegoria nos remete ao nascimento. A fala final do delegado nos lança à expectativa projetada, propondo que viver já é sofrimento suficiente. O futuro projetado para o ladrão tem base na experiência de quem está vivo e conhece as condições sociais do lugar onde vive. Como agimos no presente, único tempo real segundo Benveniste, produzimos, a partir de nossas ações, as representações do passado e do futuro. O passado histórico, como diz Koselleck comentando a máxima de Cícero (historia magistra vitae), é cheio de exemplos e, até antes da Revolução Francesa, era dele que se tiravam os ensinamentos. Assim, até o século XVIII, os homens projetavam seu futuro tomando por modelo os atos passados de seus antepassados. Com a Revolução, o homem produz o tempo sem modelos autorizados quando age e, com isso, o futuro não é mais previsível ou interpretável. Em Quino, o tempo se materializa na ação do roubo. O agir, que fundamentalmente diferencia as artes plásticas das temporais, segundo Lessing, determina o ser da alegoria temporal de Quino, porque é a partir do nascimento, ou seja, da ação de nascer, que produzimos o tempo, agindo. Com 
base nos exempla, o delegado dá a sentença final ao acusado: "Para ele já vai ser uma condenação suficiente nascer neste mundo".

Ao propor o desenvolvimento do tema do tempo na obra Grande Sertão: Veredas, havia a necessidade de escolher como estudá-lo e de quais fontes teóricas escolher para formular argumentos sobre ele. Talvez uma das maiores dificuldades do estudo do tempo no romance rosiano é que ele está totalmente entranhado na estrutura da narrativa. Quem produz a narração é Riobaldo, narrador que se apresenta como um velho, proprietário de duas fazendas, casado, católico com tendências ao espiritismo e que, de vez em quando, vai ouvir um crente metodista. Acrescentam-se a essas qualidades seus anos de estudo e sua prática de professor, que acabam levando-o à vida de jagunço num bando chefiado por um líder poderoso no sertão. Experimenta o amor de diversas espécies e maneiras: o carnal, o "esponsal", bem à moda medieval, com a noiva e a boda prometidas para depois das andanças pelo sertão, e o que o marcou mais e cuja fonte é um homem que, depois de morto, revela-se: "A Deus dada. Pobrezinha". Sua enunciação o instaura no tempo do presente, monologando dialogicamente com um interlocutor sempre mudo, figura de distanciamento, ora "doutor", ora "senhor". Armado do seu poder de palavra - herança do tempo em que ainda não era chefe, mas que o ajudou a sê-lo - o narrador inicia sua fala com " - Nonada" para terminar com o símbolo do infinito, indicando que a mimese de fala representada na escrita do livro termina, mas não os significados e o sentido do seu discurso.

O autor oculta seus recursos nas veredas da arquitetura do romance e, num primeiro momento, diz tratar-se de obra que abrange o espaço. Exato, pois ele está lá. Mas isso é apenas o superficial, já que, observando-se mais de perto o que o jogo de palavras e os diversos causos e falas camuflam, encontra-se o tempo em suas diversas manifestações. Por exemplo, como o equilíbrio verossímil da construção de um narrador (i)letrado e dominador da fala e da argumentação, com um espírito inquieto, que, por esses atributos, constitui-se como um pesquisador do passado que, portanto, elabora a estrutura de sua narração como ele mesmo é, ou seja, como um fluxo de dúvida sempre diferida e fundamental para a produção de temporalidades a partir do momento em que se sabe que é agindo na fala que se produz o agora da enunciação. Ou como as palavras, sempre inéditas na escritura de Guimarães Rosa (o que deve ser pressuposto para os que vislumbram suas "histórias da carochinha para adultos"), que desvendam universos temporais inusitados, como o do instante escondido na primeira sílaba do substantivo minuto ("nem mi de minuto"). Estudar o tempo no Grande Sertão: Veredas 
consiste, enfim, em reler incontáveis vezes o livro de muito perto e, simultaneamente, em manter a distância temporal necessária para que as coisas apareçam por si, depois de muito trabalho, trabalho, trabalho, trabalho e mais trabalho, como respondeu o autor ao crítico alemão Lorenz, quando este lhe perguntou o que achava de ser chamado de "gênio". 


\section{CAPÍTULO 1: TEORIAS SOBRE O TEMPO}

0 movimento de transcendência, que vai do futuro como possibilidade ao passado e ao presente, sem que essas dimensões possam separar-se, é a temporalidade na acepção própria da palavra, origem das diversas espécies de tempo, e que faz do homem um ser histórico. Daí dizer Heidegger que o existente humano não está no tempo: ele se temporaliza. ${ }^{1}$

Este primeiro capítulo se divide em quatro subcapítulos que abordam cada qual hipóteses e interpretações sobre o tempo. Assim, o primeiro subcapítulo "Laocoonte e o tempo nas artes" visa demonstrar, a partir do ensaio que leva o nome do personagem troiano, a distinção entre as artes espaciais e as artes temporais. O objetivo é defender a teoria de que as ações humanas representadas ficcionalmente na narrativa produzem temporalidade. Para isso nos valemos também de textos de outros estudiosos e críticos, como Benedito Nunes e Mendilow.

No segundo subcapítulo, "Santo Agostinho e o tempo da memória", focamos nossa atenção nas aporias enfrentadas pelo escritor cristão, desde a sua defesa de que Deus é o criador de todas as coisas e que, portanto, o tempo é criatura Dele, até sua conclusão sobre como podemos medir o tempo, passando pela questão acerca do ser do tempo. O objetivo desse subcapítulo é esboçar a hipótese de que a distentio animi (distensão da alma), que é dada pela atenção e pela expectativa que lança os homens ao futuro tem afinidade com a teoria da recepção da obra literária que não segue na linha reta de começo, meio e fim estabelecida por Aristóteles na Poética. Ao contrário, as anacronias, que produzem progressões e digressões, servem como estímulo ao ato de leitura.

No terceiro subcapítulo, "Koselleck e o tempo histórico", fizemos um recorte da teoria desse historiador alemão para demonstrar como o tempo histórico cristão se valeu de topoi (figuras históricas) para constituir um tempo controlado pela Igreja, que tinha em suas mãos a doutrina do fim dos tempos, já que era ela que controlava o futuro por meio das profecias. Nosso objetivo é apresentar esse tempo cristão dos fins dos tempos e também, a partir da máxima de Cícero, historia magistra vitae, expor como temos de

\footnotetext{
${ }^{1}$ NUNES, Benedito. O tempo na narrativa. São Paulo: Ed. Ática, 2002, p. 60.
} 
um lado o tempo como um ser criado por Deus - na interpretação de Santo Agostinho -, no qual os homens atuam, e outro, que surge com o Iluminismo, segundo o qual os homens produzem o tempo agindo.

Já no quarto subcapítulo, "O tempo na obra literária", há uma retomada das interpretações feitas nos três primeiros, para expor como a teoria literária se apropriou das hipóteses filosóficas e históricas sobre o tempo. Nosso intuito nessa última parte é expor como os textos literários lidaram com o tempo, principalmente a forma romanesca. Para isso, utilizamos a excelente obra $O$ tempo na narrativa, de Benedito Nunes. Por fim, concluímos com uma análise do capítulo VII, "O delírio", da obra Memórias póstumas de Brás Cubas, de Machado de Assis, para exemplificar a hipótese de que as digressões e progressões, que jogam com o tempo da narrativa e instigam o destinatário, produzem uma temporalidade interna na obra ficcional que será comprovada ao estudarmos a obra objeto de nosso trabalho, Grande Sertão: Veredas, de João Guimarães Rosa.

\title{
Laocoonte e o tempo nas artes
}

\author{
"Míseros cidadãos, que tanta insânia! \\ De volta os Gregos ou de engano isentos \\ Seus dons jul gais? desconheceis Ulisses? \\ Ou este lenho é couto de inimigos, \\ Ou máquina que, armada contra os muros, \\ Vem cimeira espiar e acometer-nos. \\ Teucros, seja o que for, há danos oculto; \\ No bruto não fieis. Mesmo em seus brindes \\ Temo os Dânaos".
}

No segundo canto da Eneida, de Virgílio, é narrada a morte de Laocoonte e seus dois filhos, Antiphantes e Thymbraeus, por duas serpentes gigantescas. Morte que ocorre porque Laocoonte fora o único dos troianos a questionar o cavalo deixado como presente pelos gregos ("Mesmo em seus brindes / Temo os Dânaos"). Assim, o sacerdote de Apolo é punido por Poseidon, deus que protege os gregos e que envia duas serpentes para silenciá-lo. Gotthold Ephraim Lessing (1729-1781), crítico que ajudou a consolidar o teatro literário na Alemanha do século XVIII, escreveu um ensaio, que

\footnotetext{
${ }^{2}$ VIRGÍLIO. Eneida. Tradução de Odorico Mendes, 2005, p. 60.
} 
continua fragmentário, intitulado Laocoonte ou sobre os limites da pintura e poesia ${ }^{3}$, que teve enorme influência no pensamento estético alemão, como afirma na "Introdução" a De teatro e literatura o crítico Anatol Rosenfeld. A seguir, o trecho em que Rosenfeld nos situa na discussão que deu origem ao ensaio de Lessing:

A influência da obra sobre o pensamento estético alemão foi enorme, mesmo entre aqueles que a combateram, como Herder. Dirigida contra toda uma corrente poética da época, ela ultrapassa, de longe, sua função histórica de polemizar contra uma poesia que, interpretando mal o "ut pictura poesis" de Horário (pintura igual à poesia) e levando ao pé da letra o aforismo de Simonides, de que "a pintura é uma poesia muda e a poesia uma pintura falante", se inebriava com "pintar" flores e paisagens. No fundo, o que Lessing desejava era combater a literatura idílica, mostrando que o domínio da literatura é a “ação”. (grifo meu) (ROSENFELD, 1964, p. 8)

Para defender sua tese de que a literatura deve se ater à ação, Lessing inicia sua exemplificação com trechos da Ilíada, de Homero. Em todos eles, o ensaísta apresenta cenas em que as personagens praticam ações. Assim, se o poeta quer mostrar como o rei Agamenon estava vestido, ele não descreve seus trajes, mas faz com que o rei se vista na nossa frente, priorizando assim a ação. Em sua teorização, Lessing faz uma distinção entre poesia e pintura, mas ao mesmo tempo mostra como uma é alusiva às características da outra. Primeiro: os corpos não existem somente no espaço, mas também no tempo, assim, "[e]les têm duração e podem, a cada momento de sua duração, aparecer de outro modo e apresentar-se em outra conexão". Portanto, "a pintura pode imitar ações, porém só de maneira alusiva através de corpos" (LESSING, 1964, p. 115-6). Segundo: a ações, apesar de existirem por si próprias, necessitam de um referente, ou seja, são inerentes a "certos seres". Dessa forma, "[n]a medida em que estes seres são corpos, ou podem ser encarados como corpos, a poesia também pinta corpos, porém só de maneira alusiva através de ações" (LESSING, 1964, p. 116). Em conclusão, a pintura deve escolher o melhor momento da ação descrita pela poesia para retratá-la, sendo que o antes e o depois ficam a cargo do receptor da obra de arte. Com isso, vemos a sucessão temporal presente tanto na pintura, como sugestão, como na poesia, já que esta descreve ações que se sucedem umas às outras. Para esclarecer esse ponto, a análise feita por Benedito Nunes, a partir do ensaio de Lessing, é exemplar.

\footnotetext{
${ }^{3}$ LESSING, Gotthold Ephraim. De teatro e literatura. Trad. de J. Guinsburg. São Paulo: Ed. Herder, 1964, p. 115-30.

${ }^{4}$ ROSENFELD, Anatol. "Introdução". in: De teatro e literatura. São Paulo: Ed. Herder, 1964, p. 7-23.
} 
Antes, recordemos o objeto do estudo de Lessing e consequentemente de Nunes, isso é, a escultura conhecida como "grupo de Laocoonte", datada do século I a.C., cuja autoria é atribuída por Plínio, o Velho ${ }^{6}$, a três escultores de Rodes, Agesandro, Atenodoro e Polidoro, e que representa a cena em que Laocoonte tenta livrar seus filhos Antiphantes e Thymbraeus dos laços das serpentes. Ao comparar os versos de Homero e a escultura helênica, o ensaísta alemão demonstra as formas de figuração das duas artes, que conseguem alcançar o belo segundo os padrões gregos. Partindo dessa comparação, Benedito Nunes escreveu sua análise, enfocando a questão do tempo. A fim de situar o leitor, Nunes (2002, p. 9-10) inicia seu estudo com a descrição da escultura:

\begin{abstract}
Na escultura, a figura central do sacerdote, que sobreleva às de seus filhos, um já exânime e o outro olhando na direção do pai - os três interligados pelas dobras monstruosas - tem a boca levemente entreaberta. A sua dor física e seu esforço espelham-se no relevo dos músculos, na posição tensa das pernas e dos braços, sem quebra das proporções que denotam a beleza no sentido grego da palavra.
\end{abstract}

Em seguida, mostra a luta como descrita por Homero:

\author{
$\mathrm{Na}$ versão literária dessa luta desigual, Laocoonte, que tenta debalde \\ desmanchar os "fatídicos nós", \\ aos astros atira clamores horrendos, \\ com isso externando a dor lancinante da qual o seu rosto na escultura não \\ revela o mais leve traço (NUNES, 2002, p. 10)
}

A pergunta é "por que o escultor omitiu, na expressão facial do sacerdote, o grito que Virgílio descreve?" (NUNES, 2002, p. 10). Com a resposta, conseguida por meio da interpretação do ensaio de Lessing, temos posta a questão do tempo:

Nada disso, responde Lessing. Ao omitir os sinais de expressão lancinante, o escultor prestou fidelidade à mesma lei da beleza diante da qual o poeta se curvara. A novidade da explicação de Lessing está na maneira de interpretar essa lei que vedava a um aquilo que permitia ao outro. A ênfase do grito no trecho de Virgílio é a culminância de uma ação progressiva, cujos momentos se sucedem no tempo, e do qual a escultura somente poderia figurar um único instante através da aparência exterior, coextensiva ao espaço, da posição estática dos corpos. (NUNES, 2002, p. 10)

\footnotetext{
${ }^{5}$ Ver figura 2.

${ }^{6}$ Volume 36 de Naturalis.
} 


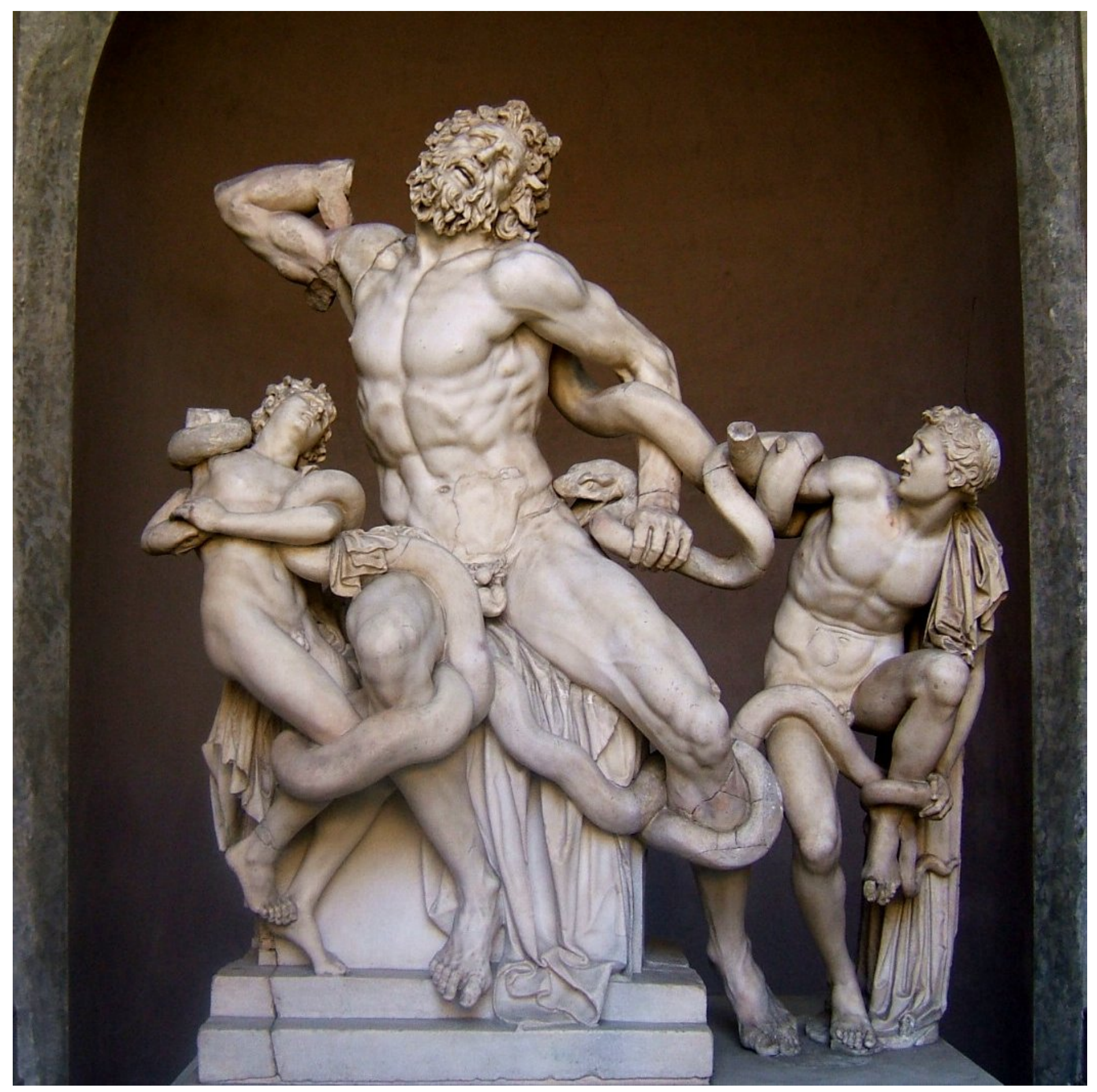

Figura 2: O grupo de Laocoonte, Museu do Vaticano. 
A sucessão de ações das personagens, descritas por meio das palavras, produz um tipo de temporalidade que está submetida a preceitos estéticos como o belo, a unidade e a mímesis. Com a interpretação dada por Lessing para a aplicação da "lei da beleza" a duas formas artísticas que representam a mesma cena, surge a dicotomia entre tempo e espaço, que exemplifica a temporalidade ligada ao signo linguístico.

\begin{abstract}
A lei da beleza traduz apenas a conformidade das representações às condições específicas que regem os meios diferentes das artes plásticas e da poesia: o espaço para as cores e figuras, o tempo para os sons articulados. As primeiras só podem representar objetos justapostos, que se chamam corpos, e eis o domínio próprio das artes plásticas, e os segundos, que são signos que se sucedem no tempo, só podem representar objetos sucessivos que se chamam ações, e eis o domínio próprio da poesia, lato sensu. (NUNES, 2002, p. 10)
\end{abstract}

As ações descritas pelas palavras estão submetidas à linearidade, que é a condição espacial do livro. O tempo, por sua vez, é constituído pela sequência das ações que ocorrem no espaço da história contada, isso é, por meio dos "sons articulados", segundo Nunes, pois se pensa em poesia. No entanto, o mesmo princípio é valido para o drama e a épica, pois esses sons articulados representam as ações das personagens por meio do signo linguístico. As artes plásticas, ao contrário, lidam com a espacialidade, o que não quer dizer que não haja temporalidade. Ela existe na liberdade que o espectador tem de percorrer e observar por diversos pontos de vista um quadro ou uma escultura e de imaginar a sugestão do antes e do depois da ação que está sendo retratada. Nesse ponto, aparece a questão do medium utilizado para constituir a obra de arte e a ilusão produzida por ela no espectador.

O crítico Abraham Adam Mendilow publicou, em 1969, seu livro sobre o tempo e o romance. No capítulo 3 da primeira parte, intitulado "As artes temporais e espaciais", o autor questiona a interpretação dada por Lessing e corroborada pelos seus seguidores, como Wyndham Lewis, que, segundo o crítico, não levam em conta "o fator de comunicação na arte" (MENDILOW, 1972, p. 27). Segundo Mendilow, Lessing não inclui o tempo do espectador na relação com a obra de arte. Incluindo o tempo do espectador, o crítico chega indiretamente à arbitrariedade do meio utilizado para expressar a obra de arte espacial ou temporal, sugerindo aproximação em momentos em que Lessing introduz diferenças. A fim de situarmos melhor a discussão, consideremos o seguinte trecho de $O$ tempo e o romance: 
O passar do olho, parte por parte, requer tempo, e a impressão de divisar o todo é produzida, em verdade, pela rápida sucessão de visões, talvez mesmo vistas de diferentes ângulos. Mesmo onde o todo possa ser divisado imediatamente, apenas uma parte é coberta pela visão focal e o resto advém somente dentro do âmbito da visão marginal. (MENDILOW, 1972, p. 28)

A arte espacial pode ser observada durante o tempo que o espectador desejar, da maneira que ele quiser - longe, perto, uma vez, várias. A ilusão de totalidade, contudo, é a mesma dada pela "leitura rápida de uma pequena peça literária" (MENDILOW, 1972, p. 28), por causa da capacidade de apreender a leitura por meio da memória. Com base nessas afirmações, Mendilow aproxima as artes espaciais das temporais, notando apenas uma diferença entre elas, como se vê abaixo:

\begin{abstract}
A quase instantânea percepção visual de uma pintura e de uma estátua tem seu equivalente na "mordida visual" da leitura. O fator que diferencia essencialmente as artes plásticas das temporais é mais que, nas primeiras, o olho pode caminhar em qualquer direção e em qualquer velocidade, no processo de acumular uma impressão do todo de um quadro ou de uma estátua. $\mathrm{O}$ espectador, pois, está livre para concentrar-se em qualquer parte de qualquer tamanho por qualquer espaço de tempo e em qualquer ordem, de acordo com seu próprio desejo e não tendo de se prender a qualquer necessidade inerente ao meio da escultura ou pintura. (MENDILOW, 1972, p. 29)
\end{abstract}

Se essa afirmação de Mendilow pode ser sustentada por seus argumentos, também é possível, então, afirmar que nem essa distinção existe entre as artes espaciais e temporais, porque o crítico só considera a primeira leitura das obras temporais (tanto o romance quanto a música). Como se posiciona a tese de Mendilow frente à recepção da obra pelo destinatário? No final do século XX, o alemão Wolfgang Iser elaborou suas teses em seu livro $O$ ato da leitura. Inicialmente, ao traçar um panorama do estudo da recepção da obra literária, Iser afirma:

Textos maiores como romances e epopeias não se fazem presentes como um todo, na leitura, com o mesmo grau de intensidade. Já os autores do século XVIII disso estavam conscientes e, por isso, discutiam nos seus romances estruturas possíveis para leitura. Um exemplo característico é a metáfora da diligência usada por Fielding e mais tarde por Scott e seus discípulos: o leitor é estilizado como viajante que, através do romance, empreende uma viagem difícil, a partir de seu ponto de vista flutuante. É evidente que ele combina, em sua memória, tudo que vê e esclarece um padrão de consistência, cuja confiabilidade depende parcialmente do grau de atenção que manteve em cada fase da viagem. Em nenhum caso, porém, a viagem inteira é disponível para o leitor a cada momento. (ISER, 1996, p. 44-5) (grifo meu) 
Assim, se se admite a tese de Mendilow, também é verdadeiro que, com uma teorização do ato de comunicação, tanto as obras de arte espaciais como as temporais se assemelham na recepção, porque para as segundas é importante considerar não a primeira leitura, mas sim as possíveis releituras que o leitor ou ouvinte podem realizar. Essas releituras são mais corriqueiras no ciclo dos estudiosos das obras temporais. Portanto, o que realmente diferencia a escultura e a pintura de um romance ou de uma música é o medium pelo qual a obra é expressa pelo autor. Em conclusão, ambas as espécies, pintura e literatura, são obras temporais, e o que pode distingui-las é o "grau de intensidade" de apreensão aplicado pelo espectador tanto em uma quanto em outra.

Já o signo linguístico, medium da obra literária, pelo fato de ser discreto e sequencial, impõe a ordem temporal do "isso depois daquilo" ao leitor, porque a narração de uma ação, necessariamente, leva tempo para ser lida e apreendida. É nesse sentido que entendemos que a recepção das obras de artes espaciais e temporais é distinta, porque o primeiro contato, temporalmente, é diferente entre elas. Por exemplo, o tempo da primeira observação de uma pintura é mais longo do que o da leitura de uma epopeia. Contudo, a distinção para aí, pois a análise de uma e de outra é possível pela releitura de trechos de interesses que permaneceram na memória do leitor do poema ou pelo olhar dirigido a vários ângulos por parte do observador da pintura.

\section{Santo Agostinho e o tempo da memória}

O tempo pode ser medido em horas, minutos, segundos e milionésimos de segundo, mas conceituar o tempo é das tarefas mais difíceis. Prova disso são os pensadores que, ao tentarem defini-lo, lidaram com muitas aporias e paradoxos. Não a primeira, mas com certeza a mais conhecida das reflexões sobre o tempo é a de Santo Agostinho, quando, no Livro XI das Confissões, intitulado "Meditação sobre o primeiro versículo do Gênesis: 'No princípio Deus criou...’”, nos diz:

Por conseguinte, o que é o tempo? Se ninguém me pergunta, eu sei; porém, se quero explicá-lo a quem me pergunta, então não sei. No entanto, posso dizer com segurança que não existiria um tempo passado, se nada passasse; e não existiria um tempo futuro, se nada devesse vir; e não haveria o tempo presente se nada existisse. (AGOSTINHO, 2006, p. 342-3) 
A conceituação do tempo começa com definições do que ele não é, o que nos leva à indagação inicial de Santo Agostinho, demonstrando a dificuldade de definir o que parece tão óbvio no dia a dia. Essa questão do tempo tem por pressuposto uma discussão anterior, que é a do que fazia Deus antes da criação. A resposta do teólogo é: "Antes de criar o céu e a terra, Deus não fazia nada" (AGOSTINHO, 2006, p. 341). Antes que a acusação de heresia caia sobre o santo, é com perspicácia que Agostinho diz: "Pois, se tivesse feito alguma coisa, o que poderia ser, senão uma criatura?" (AGOSTINHO, 2006, p. 341). Afirmar, portanto, que Deus fazia algo antes da criação do tempo é dizer que Ele é uma criatura, sendo que, para o santo cristão, Deus é o Criador de todas as coisas, inclusive do tempo. Em outras palavras, Ele é a Causa Primeira. Então, por não fazer nada, pois é ato puro, é que Lhe é dado o poder de Criador. É dessa maneira que Agostinho conclui suas meditações sobre o que fazia Deus antes da criação do Céu e da Terra:

\footnotetext{
Que tempo poderia existir, se não fosse estabelecido por ti? E como poderia esse tempo transcorrer, se nunca tivesse existido? Portanto, sendo tu o Criador de todos os tempos - se é que existiu algum tempo antes da criação do céu e da terra - como se pode dizer que cessavas de agir? De fato, foste tu que criaste o próprio tempo, e ele não podia decorrer antes de o criares. (AGOSTINHO, 2006, p. 341)
}

Para Deus há a eternidade, na qual os tempos presente, passado e futuro não transcorrem, e mais, não existem. Dessa maneira, esse tempo não-tempo (no singular) é antecedente dos tempos (no plural), o que só é possível porque o tempo, pensado como eternidade, foi gerado coeterno a Deus. Essa definição de tempo serve para comprovar o poder do Criador na medida em que Deus é eterno, isso é, não muda. Ele é sempre atual e, assim sendo, domina todos os tempos como seres criados por Ele. Vejamos o parágrafo 16 do livro XI:

Mas não é no tempo que tu precedes os tempos, pois, doutro modo não serias anterior a todos os tempos. Precedes, porém, todo o passado com a sublimidade de tua eternidade sempre presente, e dominas todo o futuro porque é ainda futuro, e, quando vier, tornar-se-á passado. "Tu, porém, és sempre o mesmo, e os teus anos jamais terão fim". Os teus anos não vão nem vem, ao passo que os nossos vão e vêm, para que venham todos. Os teus anos existem juntos, porque são fixos e não são expulsos pelos que vêm, porque não passam. Os nossos, pelo contrário, só poderão existir todos quando já não existirem. "Os teus anos são como um só dia", e o teu dia não é cada dia, mas hoje, porque o teu hoje não cede lugar ao amanhã nem sucedeu ao ontem. O teu hoje é a eternidade. Por isso geraste coeterno contigo aquele a quem disseste: "Eu hoje te gerei". Criaste todos os tempos e existes antes de 
todos os tempos. E não existia tempo quando não havia tempo. (AGOSTINHO, 2006, p. 341-2) (grifos meus)

Ocorre, portanto, a cisão entre o tempo do homem, que passa a ser definido como sujeito do tempo, porque age dentro dos limites temporais, e o tempo de Deus, que não existe como o nosso, mas é coexistente ao Criador e, assim, não passa, porque ambos são eternos. Dessa maneira, segundo a interpretação do santo patrístico, há duas categorias básicas de tempo que devemos considerar antes de nos estendermos a outras interpretações. A primeira é o tempo eterno, que é coeterno a Deus, e a segunda, os tempos presente, passado e futuro, nos quais os homens vivem e morrem. Para Deus o tempo não passa e Ele vê todo o passado e o futuro simultaneamente; já para os homens, o futuro só será observável quando já estiver extinto e se tornar passado, ou seja, após a morte. O tempo, assim definido, é a representação da força do Criador, demonstrando que tudo o que parte Dele é criatura subordinada, principalmente o homem, que é inferior a Deus e também ao tempo e tem que se submeter a ambos. Isso posto, Santo Agostinho adianta sua meditação, adentrando a problemática do tempo em si, que nos remete à aporia já citada na primeira deste estudo. Como, portanto, dizer o que é o tempo, sendo que sua natureza está apenas em nossa percepção?

A resposta à questão está relacionada ao ser e não-ser do tempo, que por sua vez levam à questão da medição do tempo. O ser e não-ser do tempo estão implícitos na pergunta inicial de Agostinho: "Por conseguinte, o que é o tempo?" Se se pergunta sobre o que é o tempo, pressupõe-se que ele seja, posto que falamos dele, mas realmente existe, como o percebemos, já que o passado não é mais, o futuro não é ainda e o presente não permanece? O filósofo francês Paul Ricoeur inicia seu livro Tempo $e$ narrativa a partir de uma análise minuciosa das Confissões de Santo Agostinho. É ele quem levanta a importância da linguagem como argumento para a existência de um ser para o tempo:

Em nome de que proferir o direito de o passado e o futuro serem de algum modo? Ainda uma vez, em nome do que dizemos e fazemos a propósito deles. Ora, o que dizemos e fazemos quanto a isso? Narramos as coisas que consideramos verdadeiras e predizemos acontecimentos que ocorrem tal como os havíamos antecipado. É pois sempre a linguagem, assim como a experiência e ação, que esta articula, que resiste ao assalto dos céticos. (RICOEUR, 1994, p. 25-6) 
Nesse trecho o filósofo francês defende, com Agostinho, a existência do ser do passado e do futuro. A mesma afirmação é feita com relação ao tempo em geral, que inclui o presente, na medida em que a primeira afirmação de o tempo ser é que nós falamos dele, sentimos sua passagem e podemos até comparar intervalos temporais.

Todavia, Senhor, percebemos os intervalos do tempo, comparamos um com o outro, e afirmamos que uns são mais longos, outros mais breves. Medimos também quanto um tempo é mais longo ou mais breve que outro, e depois afirmamos que este é o dobro ou o triplo, enquanto aquele é simples; ou, ainda, dura tanto este quanto aquele. (AGOSTINHO, 2006, p. 345-6)

Assim, o que mantém a existência do tempo é a experiência humana, "articulada pela linguagem e esclarecida pela inteligência” (RICOEUR, 1994, p. 24). Mas a questão do ser e do não-ser do tempo nos encaminha a outra questão: como medimos o tempo? A resposta mais direta é que medimos o tempo porque ele ocupa um lugar e esse lugar é o espírito, também chamado de alma, e que é sinônimo de mente, que, por sua vez, significa memória. O único tempo que realmente existe, segundo Santo Agostinho, é o presente, enquanto o passado e o futuro têm sua existência subordinada a ele. Então, o passado não existe porque já acabou e o futuro também não existe na medida em que ainda não aconteceu. A princípio parece haver uma negação do passado e do futuro, mas que logo em seguida é rechaçada, porque tanto o futuro como o passado existem na medida em que podem ser percebidos ${ }^{7}$.

Neste momento chegamos ao ponto mais interessante da doutrina do tempo de Santo Agostinho, isso é, o ponto em que ele define a existência dos três tempos. Primeiramente, é preciso saber que o tempo que realmente existe, ou melhor, o que evoca os outros, é o presente: "Se ainda não consigo compreender, todavia sei que, onde quer que estejam, não serão futuro nem passado, mas presente" (AGOSTINHO, 2006, p. 346-7). Para tornar as definições mais claras, vejamos dois trechos da Confissões, livro XI:

No primeiro, (AGOSTINHO, 2006, p. 347), ele nos diz:

\footnotetext{
${ }^{7}$ AGOSTINHO, 2006, p. 347: "Pai, eu busco, não afirmo. Ó Deus, vigia os meus passos e guia-me. Quem se atreveria a dizer-me que não há três tempos — conforme aprendemos na infância e ensinamos às crianças, isto é, o passado, o presente e o futuro, - mas somente o presente, porque os outros dois não existem? Ou poderemos dizer que eles realmente existem, e que o futuro, tornando-se presente, sai de algum lugar oculto, e que, tornando-se passado, torna a entrar em algum lugar secreto? Na realidade, aqueles que predisseram o futuro, onde é que o viram, se ainda não existia? Não se pode ver o que não existe. E aqueles que narram coisas passadas, não poderiam relatar coisas verdadeiras, se não as vissem na mente. Ora, se o passado realmente não existisse, de modo algum poderia ser percebido. De onde se conclui que tanto o futuro como o passado existem.”
} 
Quando narramos os acontecimentos passados, que são verdadeiros, nós os tiramos da memória. Mas não são fatos em si, uma vez que são passados, e sim as palavras que exprimem as imagens que os próprios fatos, passando pelos sentidos, deixaram no espírito. Minha infância, que não existe mais, está no passado, que também não mais existe. Mas a imagem dela, quando a evoco e é objeto de alguma conversa, eu a vejo no presente, porque está ainda na minha memória. (grifos meus)

A memória é o receptáculo no qual o passado existe e ele existe no instante em que é evocado pelo presente. Contudo, não é o fato passado que passa a existir no presente, mas sim uma imagem que, "passando pelos sentidos", ainda existe no espírito humano. Essa imagem não corresponde ao fato tal como aconteceu, mas sim a uma representação do fato.

Já no segundo trecho (AGOSTINHO, 2006, p. 347), o futuro é assim definido:

Confesso-te, meu Deus, que não sei se é análogo o caso da predição do futuro, com a qual se preveem, como já existentes, as imagens das coisas que ainda não existem. Sei com certeza que nós premeditamos nossas ações futuras e que tal premeditação é presente, mas o ato que premeditamos ainda não existe, porque é futuro. Quando empreendermos e começarmos a realizar o que premeditávamos, então esse ato existirá, pois não será mais futuro, e sim presente. (grifo meu)

O futuro é ação do ato de premeditar, que ocorre também na mente. O passado corresponde ao resgate de uma imagem através da memória, que também existe em nossa mente. Assim, concluímos que tanto o futuro como o passado existem no presente a partir da ação de nossa mente, que projeta o futuro, mas também rememora o passado e vê o presente:

\footnotetext{
Agora está claro e evidente para mim que o futuro e o passado não existem, e que não é exato falar de três tempos - passado, presente e futuro. Seria talvez mais justo dizer que os tempos são três, isto é, o presente dos fatos passados, o presente dos fatos presentes, o presente dos fatos futuros. E estes três tempos estão na mente e não os vejo em outro lugar. O presente do passado é a memória. O presente do presente é a visão. O presente do futuro é a espera. (AGOSTINHO, 2006, p. 348-9) (grifos meus)
}

A memória, a visão e a espera definem, portanto, os três tempos. Para Santo Agostinho, é a ação da mente que governa os tempos, o que faz com que o homem produza o tempo. Porém, não podemos nos esquecer da dicotomia inicial: há o tempo e os tempos. Esses três tempos que podem ser percebidos pelo homem estão subordinados ao tempo que é coeterno a Deus e representativo de seu poder de Criador. 
Ao caracterizar a mente como locus dos tempos, Agostinho produziu a base para a conclusão de sua análise do tempo, isso é, dizer qual é a duração do tempo, sua extensão, ou melhor, como o medimos.

Segundo o doutor cristão, é com o espírito que medimos a extensão do tempo. Antes de avançarmos, voltemos um pouco na definição de espírito ou alma. Agostinho o aproxima, no livro $\mathrm{X}$, da memória:

[...] a memória também é o espírito. De fato, quando recomendamos a alguém que grave algo na memória, dizemos: "Vê lá, grava-o bem no teu espírito". E se nos esquecemos, dizemos: "Não conservei no espírito"; ou ainda: "Fugiu-me do espírito", assim, chamamos justamente a memória de espírito. (AGOSTINHO, 2006, p. 285)

Porém, a memória não é exatamente o espírito, e sim uma parte dele, caso contrário, como se responderiam às seguintes perguntas:

Sendo assim, por que será que, evocando com alegria uma tristeza passada, a alma contém a alegria, e a memória contém a tristeza? Se o espírito está alegre contendo em si a alegria, por que a memória, que também contém a tristeza, não está triste? Será que a memória não faz parte da alma? (AGOSTINHO, 2006. P. 285)

Para esclarecer essas dúvidas, compara-se a memória ao estômago da alma:

O fato é que a memória é, por assim dizer, o estômago da alma. A alegria e a tristeza são como alimento, que ora é doce, ora é amargo. Quando tais emoções são confiadas à memória, podem ser aí despertadas como num estômago, mas perdem o sabor. Seria ridículo querer comparar sentimentos com alimentos; no entanto, não são completamente diferentes. (AGOSTINHO, 2006, p. 285)

O texto possui seu humor, que é logo deixado de lado porque Agostinho quer demonstrar que o espírito - e aí a memória tem papel importante - é que permite perceber a duração do tempo. Como o espírito, ou alma, pode medir o tempo? Paul Ricoeur afirma que a medição do tempo se dá pela distensão da alma humana, que se torna o ponto de referência, isolando, portanto, o argumento de que o tempo seria o movimento dos astros:

Quando ele diz que o tempo é, antes, a medida do movimento do que o próprio movimento, não é num movimento regular dos corpos celestes que ele está pensando, mas na medida do movimento da alma humana. Com efeito, se se admite que a medição do tempo se faz por comparação entre um tempo mais longo e um tempo mais curto, é preciso um termo fixo de 
comparação; ora, este não pode ser o movimento circular dos astros, posto que admitimos que poderia variar. O movimento pode parar, o tempo não. (RICOEUR, 1994, p. 33)

Para Ricoeur, o autor da Patrística é audaz, pois só ele afirmou a medição de um espaço de tempo sem relação ao movimento dos corpos celestes: "Só Agostinho ousa admitir que se pode falar de espaço de tempo - um dia, uma hora - sem referência cosmológica" (RICOEUR, 1994, p. 32). Em vez da cosmologia, Agostinho usa a distensão da alma como referência: "A noção de distentio animi servirá precisamente de substituto a esse suporte cosmológico do espaço de tempo" (RICOEUR, 1994, p. 32).

Para demonstrar a distentio animi, Agostinho usa como exemplo o verso Deus creator omnium (AGOSTINHO, 2006, p. 357), composto por sílabas breves (as ímpares) e longas (as pares) alternadas entre si. Para ele, é possível medi-las porque, ao compará-las, há "alguma coisa delas que permanece gravada na [...] memória" (AGOSTINHO, 2006, p. 358). Essa coisa é a impressão do que acabou de acontecer. Assim, conclui-se:

É em ti, meu espírito, que eu meço o tempo. [...] Meço, enquanto está presente, a impressão que as coisas gravam em ti no momento em que passam, e que permanece mesmo depois de passadas, e não as coisas que passaram para que a impressão se reproduzisse. É essa impressão que meço, quando meço os tempos. (AGOSTINHO, 2006, p. 358)

Tudo poderia ser resumido na seguinte frase: "[...] aquilo que a alma espera torna-se lembrança depois de ser objeto da atenção" (AGOSTINHO, 2006, p. 359).

Substituindo "espera" por futuro, "lembrança" por passado e "atenção" por presente, temos os predicados que permitem afirmar que a alma é o ponto de referência para medir o passar do tempo:

\begin{abstract}
Se estou para recitar uma canção que conheço, antes de começar, já minha expectativa se estende a toda ela. Mas, assim que começo, tudo o que vou destacando e entregando ao passado vai se estendendo ao longo da memória. Assim, a minha atividade volta-se para a lembrança da parte já recitada e para a expectativa da parte ainda a recitar; a minha atenção, porém, está presente: por seu intermédio, o futuro torna-se passado. E quanto mais avança o ato tanto mais se abrevia a espera e se prolonga a lembrança, até que esta fica totalmente consumida, quando o ato, totalmente acabado, passa inteiramente para o domínio da memória. (AGOSTINHO, 2006. P. 359-60)
\end{abstract}

A memória é, portanto, segundo o exemplo citado, início e fim da extensão temporal. Com a distentio animi é possível a Agostinho sustentar sua tese da 
triplicidade do presente: "o presente dos fatos passados, o presente dos fatos presentes, o presente dos fatos futuros" (AGOSTINHO, 2006, p. 349).

\section{Koselleck e o tempo histórico}

Historia magistra vitae. Essa máxima de Cícero orientou a maneira de interpretar a história até o século XVIII, antes da Revolução Francesa. Atualmente, ela não faz mais sentido, perdeu o poder que possuía, pois se antes o passado era fonte de exemplos (exempla) e com isso era confiável para projetar o futuro, após 1800 já não é mais atribuído àquele tempo o fundamento da experiência e a esse a capacidade de se relacionar com as experiências passadas para se projetar. Nosso intuito é estudar uma parte da constituição do tempo histórico, relacionada às figuras históricas. Portanto, nossa atenção é voltada para a recepção da máxima de Cícero e como ela influenciou a formação do "tempo cristão". Para isso, usaremos como base Futuro Passado ${ }^{8}$ do estudioso alemão Reinhart Koselleck. Comecemos pelo tempo da Revolução para depois chegarmos ao cristão:

\footnotetext{
Se o futuro da história moderna abre-se para o desconhecido e, ao mesmo tempo, torna-se planejável, então ele tem de ser planejado. A cada novo plano, introduz-se um novo elemento que não pode ser objeto da experiência. $\mathrm{O}$ aspecto arbitrário da história cresce paralelamente à sua capacidade de realização. Um sustenta a outra e vice-versa. Ambos compartilham da destruição do espaço tradicional da experiência, o qual, até então, parecia ser determinado a partir do passado. (KOSELLECK, 2006, p. 57) (grifos meus)
}

Essa afirmação está no final do segundo capítulo da primeira parte do seu livro, Futuro Passado. Nesses dois capítulos, o historiador analisa a máxima de Cícero, culminando no trecho citado, no qual, segundo ele, a partir da Revolução Francesa, o futuro torna-se "planejável" e, com isso, ocorre a negação dos exemplos do passado como campo de experiência. Para tornar isso claro, é preciso reconstituir a análise de Koselleck a partir do topos historia magistra vitae, pois é nele que nos basearemos para demonstrar o tempo criado a partir das ações humanas. Com base em Cícero, o filósofo alemão demonstra como o conceito de tempo se inverte em relação àquele definido por

\footnotetext{
${ }^{8}$ KOSELLECK, Reinhart. Futuro passado: contribuição à semântica dos tempos históricos. Trad. Wilma Patrícia Maas, Carlos Almeida Pereira. Rio de Janeiro: Ed. PUC-Rio, 2006.
} 
Santo Agostinho, pois agora a temporalidade, antes criatura de Deus, surge das ações e exemplos dos seres humanos:

\begin{abstract}
Historia vero testis temporum, lux veritatis, vita memoriae, nuntia vetustatis, qua voce alia nisi oratoris immortalitati commendatur [A história é a testemunha dos tempos, a luz da verdade, a vida da memória, a mensageira da velhice, por cuja voz nada é recomendado senão a imortalidade do orador.] A tarefa principal que Cícero atribui aqui à historiografia é especialmente dirigida à prática, sobre a qual o orador exerce sua influência. Ele se serve da história como coleção de exemplos - plena exemplorum est historia [a história é cheia de exemplos] — a fim de que seja possível instruir por meio dela. (KOSELLECK, 2006, 43)
\end{abstract}

Os trechos citados em latim por Koselleck são da obra De Oratore, de Cícero. Ao atribuir ao orador a pragmática de ensinar por meio dos exemplos da história, há a subordinação do tempo aos exemplos humanos (exempla). Com o Iluminismo e depois dele, a historiografia produz o conceito de tempo histórico e é através dela que ele passa a existir. Lembrando que o contexto dos trechos de Cícero é o da oratória, no qual o “orador é capaz de emprestar um sentido de imortalidade à história como instrução para a vida, de modo a tornar perene o seu valioso conteúdo de experiência" (KOSELLECK, 2006, p. 43), a História passa a ser detentora de bons e maus exemplos de figuras (topoi) históricas. Koselleck exemplifica sua teoria por meio de uma obra de arte. Ele se vale da pintura Batalha de Alexandre ${ }^{9}$, de Albrecht Altdorfer, encomendada pelo duque Guilherme IV da Baviera.

\footnotetext{
${ }^{9}$ Ver figura 3.
} 


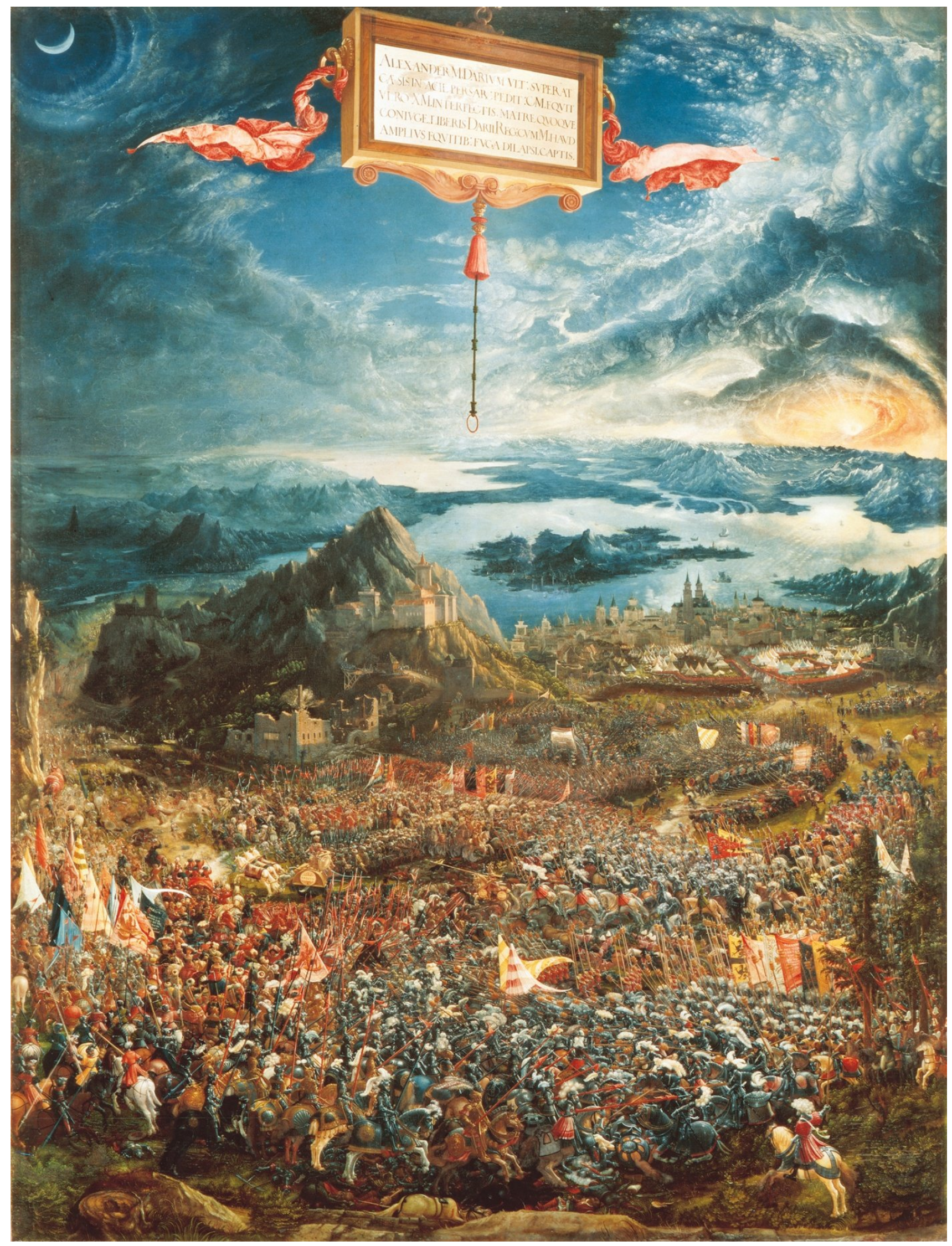

Figura 3: Batalha de Alexandre. 
Koselleck faz duas interpretações para o quadro da Batalha de Alexandre. Na primeira, o rei da Macedônia é tomado como um arquétipo, uma figura histórica, como se lê a seguir:

\begin{abstract}
Quando contemplamos o quadro na Pinacoteca de Munique, somos confrontados com mais um anacronismo notável: acreditamos ver à nossa frente Maximiliano, o último cavaleiro, e as hordas de lansquenetes da Batalha de Pavia. A maioria dos persas assemelha-se, dos pés aos turbantes, aos turcos, que, no mesmo ano de composição do quadro (1529), sitiaram Viena, sem resultado. Em outras palavras, Altdorfer captou um acontecimento histórico que era, ao mesmo tempo, contemporâneo para ele. Alexandre e Maximiliano (Altdorfer pintou o quadro para este último) assemelham-se de maneira exemplar. (KOSELLECK, 2006, p. 22)
\end{abstract}

Koselleck mostra como a batalha de Maximiliano, que é contemporânea do pintor Altdorfer, é retomada no momento de elaboração do quadro que representa a batalha de Alexandre. Por esse motivo, Alexandre torna-se uma figura histórica, um arquétipo, pois sua batalha contra os persas foi "exemplar" e assim também o é, para o artista, a luta de Maximiliano contra os turcos. A segunda interpretação toma como referência a leitura do quadro feita por um cristão contemporâneo do pintor, ou seja, tem por base a recepção da obra de arte:

\begin{abstract}
Tentemos observar o quadro com os olhos de um contemporâneo da época. Para um cristão, a vitória de Alexandre sobre os persas significou a passagem do segundo para o terceiro império temporal [Weltreich], ao qual deveria suceder o quarto e último, o Sacro Império Romano. [...] A batalha na qual o Império Persa deveria perecer não foi uma batalha qualquer, mas sim um dos poucos eventos situados entre o começo e o fim do mundo, que prenunciava também o fim do Sacro Império Romano.

Os contemporâneos de Altdorfer esperavam a ocorrência de eventos análogos, para que ocorresse o fim do mundo. Em outras palavras, o quadro de Altdorfer tinha caráter escatológico. A batalha de Alexandre era atemporal como modelo, como figura ou arquétipo de uma luta final entre Cristo e Anticristo; os que lutavam ali eram contemporâneos de todos aqueles que viveram aguardando o Juízo Final. (KOSELLECK, 2006, p. 23-4)
\end{abstract}

As figuras exemplares têm plena existência histórica em si mesmas, mas Altdorfer e seus contemporâneos, no século XVI, pressupunham que há um princípio criador de ambas, Deus, que torna Alexandre uma prefiguração de Maximiliano; este, por sua vez, revela o que foi profetizado por Alexandre. No caso, a batalha representada entre Alexandre e os persas figura a batalha contemporânea entre Maximiliano e os turcos. Metaforicamente, essas batalhas são figuras de um arquétipo, a luta final entre Cristo e o Anticristo. Esse conceito providencialista de história foi doutrinado pela 
Igreja Católica, que desde muito cedo passou a deter o monopólio do tempo futuro (Juízo Final) e, com isso, a controlar também o tempo da morte, manipulando, consequentemente, o tempo da vida.

\begin{abstract}
A Igreja Romana tinha por princípio dominante manter sob seu controle todos os visionários. Segundo decisão do Concílio Lateranense (1512 a 1517), era preciso uma autorização da Igreja para o anúncio de visões do futuro. A proibição da doutrina joaquimita do Terceiro Reino, o destino de Joana D'Arc, a qual, pela firma convicção de suas visões não autorizadas, teve que subir à fogueira, ou a morte por fogo de Savonarola podem servir de exemplo de como as profecias pós-bíblicas foram dizimadas. A existência da Igreja não podia ser ameaçada, sua unidade - assim como a existência do Império - era a garantia de ordem até que sobreviesse o fim do mundo. (KOSELLECK, 2006, p. 25)
\end{abstract}

O tempo futuro passa, então, a ser atrelado à própria história da Igreja Romana, que tratou de eliminar novas profecias, pois o possível fim do mundo não está localizado linearmente no fim dos tempos, mas sim na própria constituição da Igreja, que passa a representar a salvação.

\begin{abstract}
Em consequência disso, o futuro do mundo, assim como o seu fim, foram incorporados à própria história da Igreja, o que faz com que novas e flamejantes profecias fossem necessariamente consideradas heresias. A expectativa do fim do mundo tornou-se parte integrante da própria Igreja como instituição, de tal modo que esta pôde se estabilizar tanto sob a ameaça de um fim do mundo que poderia acontecer a qualquer momento como na esperança da parúsia. (KOSELLECK, 2006, p. 26)
\end{abstract}

Esse domínio da Igreja sobre o fim dos tempos é substituído, na época das revoluções, no século XVIII, pelo medo de que o fim do Estado Absolutista chegue. Por isso, ele passa a controlar o tempo futuro, como se vê na interpretação que faz o historiador José Carlos Reis no seu livro História, a ciência dos homens no tempo (2009, p. 82):

\footnotetext{
Entre esse "tempo cristão" acelerado e o tempo também acelerado das filosofias da história, mas em direções diversas, Koselleck põe o tempo do Estado Absolutista, que teme aquelas acelerações, em que percebe o seu fim, e procura ampliar o espaço da experiência, pelo controle do horizonte de espera por meio do prognóstico, do cálculo e de uma concepção naturalista do tempo, isto é, "nada de novo pode ocorrer".
}

A exposição dessas categorias de tempo de Koselleck é necessária para que possamos chegar à sua hipótese, que é a de um "ser" para o tempo histórico. Este, porém, não possui relação com o de Santo Agostinho. A reflexão aqui gira em torno de 
duas categorias: "campo de experiência" e "horizonte de expectativa". Elas servem para que o autor alemão consiga formular sua definição de tempo histórico, que é tempo heterogêneo, pois não há um único tempo, mas sim tempos plurais, na medida em que cada sociedade moderna constitui seu próprio tempo, baseada em suas experiências e em suas expectativas. O tempo histórico, portanto, está centrado na produção do presente da história, ou seja, em como ela interpreta o passado e cria prognósticos para o futuro. Novamente, José Carlos Reis nos proporciona um comentário preciso sobre a funcionalidade do tempo histórico de Koselleck:

\begin{abstract}
No mundo moderno, então, a diferença entre experiência e espera não para de crescer; no mundo camponês e artesão anterior, vivia-se conforme a natureza, isto é, as esperas eram mantidas, viviam-se as experiências e as esperas dos mais velhos. A mudança era lenta e não ameaçava o mundo tradicional. Aqui, a história se faz, lá a história é feita; a história que se faz ensina, já a história que é feita não ensina. Essas diferenças entre experiência e espera, termina Koselleck, são plurais, isto é, o tempo histórico não é um, mas sim múltiplos que se superpõem. (REIS, 2009, p. 86)
\end{abstract}

Com base nessas informações, passemos agora a relacionar as três concepções de tempo dos autores estudados com o tempo na obra literária.

\title{
O tempo na obra literária
}

Não importa ao tempo o minuto que passa, mas 0 minuto que vem. 0 minuto que vem é forte, jucundo, supõe trazer em si a eternidade, e traz a morte, e perece como 0 outro, mas o tempo subsiste. Egoísmo, dizes tu? Sim, egoísmo, não tenho outra lei. Egoísmo, conservação. A onça mata o novilho porque o raciocínio da onça é que ela deve viver, e se o novilho é tenro tanto melhor: eis 0 estatuto universal. Sobe e olha. ${ }^{10}$

Depois de analisadas as teorias acima, o objetivo deste subcapítulo é demonstrar como essas teorias sobre o tempo, que se referem ao tempo vivido e ao da história, atuam nas formas de tempo da obra literária. Este, portanto, é um subcapítulo de transição. Para cumprirmos nosso intuito, utilizaremos como obra de referência o livro do crítico brasileiro Benedito Nunes, O tempo na narrativa. Nesse livro o autor faz uma

\footnotetext{
${ }^{10}$ Assis, Machado de. Memórias póstumas de Brás Cubas. São Paulo: Globo, 1997, p. 14.
} 
coletânea dos estudos do tempo, abordando-o desde a mimesis praxeos de Aristóteles, passando pela teoria do tempo físico de Newton e Einstein e a fenomenologia do tempo vivido de Husserl e Heidegger até chegar a estudiosos como Paul Ricoeur, Mendilow, Pouillon, Weinrich, que discutiram os conceitos de tempo relacionado à narrativa, em particular, e à obra literária, em geral.

Com Lessing, vimos que o tempo se constitui de ações humanas representadas por sons que são representados, por sua vez, pelos signos linguísticos. Num romance, por exemplo, o tempo acontece pela narração dos acontecimentos. Contudo, apesar de toda história narrada estar inserida no tempo e seus acontecimentos representarem o tempo, parece não existir obra literária que aborde única e exclusivamente o tempo. Essa constatação paradoxal é feita pelo narrador de Thomas Mann no seu livro $A$ montanha mágica (2000, p. 739), que pergunta: "Pode-se narrar o tempo, o próprio tempo, o tempo como tal e em si?", e ele mesmo responde:

\footnotetext{
Não, isso seria deveras uma empresa tola. Uma história que rezasse: "O tempo decorria, escoava-se, seguia o seu curso" e assim por diante nenhum homem de espírito são poderia considerá-la história. Seria como se alguém tivesse a ideia maluca de manter durante uma hora um e mesmo tom ou acorde e afirmasse ser isso música (MANN, 2000, p. 739).
}

Apesar de não ser possível falar do tempo em si, ele é o elemento imprescindível da narrativa, como afirma o narrador: "O tempo é o elemento da narrativa, assim como é o elemento da vida; está inseparavelmente ligado a ela, como aos corpos no espaço" (MANN, 2000, p. 739). Benedito Nunes inicia seu livro a partir desse paradoxo, que apresenta da seguinte maneira:

Eis o primeiro paradoxo que enfrentamos: para narrar — e também para criar musicalmente - precisamos do tempo. Mas somente a narrativa e a criação musical possibilitam divisá-lo em formas determinadas. (NUNES, 2002, p. 6)

Segundo o crítico, o primeiro passo é buscar uma relação entre as formas de narrativas - às quais o tempo é essencial - e os gêneros literários, tendo como suporte de fundo as medidas temporais utilizadas na música:

É mais fácil compreender as ligações do tempo com a música por ser esta basicamente articulada segundo medidas temporais (ritmo, compasso e andamento ou velocidade), do que com as formas narrativas, nas quais se apresenta quase sempre de modo implícito (NUNES, 2002, p. 6). 
Fiquemos com a comparação entre as formas narrativas e a música para estudarmos essas figuras de duração que constituem o ritmo das narrações. Pensando em romances ou epopeias, há basicamente dois tipos de variações de duração: o sumário e o alongamento. Segundo Benedito Nunes, essas duas variações são análogas aos movimentos das formas musicais sonata, allegro e andante, respectivamente (NUNES, 2002, p. 34). O sumário imprime rapidez à narrativa e sua consequência é "que abrevia os acontecimentos num tempo menor do que o de sua suposta duração na história" (NUNES, 2002, p. 34). Já o alongamento produz o efeito contrário, pois "o discurso dura mais do que a história". Ele está presente principalmente em romances que se constituem de narração e digressão (NUNES, 2002, p. 35). Entre eles, segundo Nunes, surge mais um recurso:

Entre o sumário e o alongamento, intercala-se a figura da cena, não necessariamente dialogada: o discurso corresponde, aproximadamente, ao tempo dos acontecimentos [...] (NUNES, 2002, p. 35)

Esses três recursos são importantes na medida em que estruturam a narrativa a partir de categorias temporais de andamentos. Eles são, pois, "figuras retóricas avalizadoras do estatuto fictício do texto" (NUNES, 2002, p. 35).

A partir disso, podemos pensar melhor na cena como espaço temporal de atualização do presente de enunciação. Para isso, é fundamental a hipótese do filósofo alemão Harald Weinrich, cujo principal mérito, segundo avaliação de Benedito Nunes, foi

[...] desvincular o tempo da linguagem do sistema de divisão gramatical pautado na equivalência do presente, do passado e do futuro com a ordem natural das coisas, em proveito da temporalidade própria do texto (Textzeit), sempre relacionado com o tempo de ação (Aktzeit), enquanto conteúdo de comunicação. (NUNES, 2002, p. 40)

Essa tese de Weinrich possui uma característica comum à concepção de tempo que Lessing estabelece com a epopeia, que é o tempo de ação. Quando se pensa nessa temporalidade, deve-se priorizar o movimento. Considerando-o, é que os dois autores podem relacionar o tempo de ação à comunicação. Citando Homero, Lessing elogia-o por privilegiar a ação, fazendo com que as descrições e apresentações de objetos surjam por meio dela. Assim, quando o aedo vai apresentar o cetro de Agamêmnon, ele o faz por meio da história do objeto, demonstrando, acima de tudo, sua importância: 
[...] Levanta-se o forte Agamémnone, nas mãos o cetro que Hefesto com muito artifício forjara para presente fazer a Zeus pai, que de Crono nascera. O mensageiro veloz, por sua vez, foi por Zeus presenteado, Hermes, que a Pélope o entrega, o senhor domador de cavalos; Pélope, então, o passou para Atreu, o pastor de guerreiros, que para Tiestes o deixa ao morrer, opulento em rebanhos; para Agamémnone Tiestes o deu, porque, firme, o empunhasse e em muitas ilhas o mando tivesse, bem como em toda Argos. (HOMERO, 2001, p. 80)

Para o hiperbólico autor de Laocoonte, a técnica narrativa de Homero é tão bela que se conhece melhor o cetro da maneira apresentada do que se ele próprio o tivesse em suas mãos: "Dessarte, acabo conhecendo o referido cetro melhor do que o pintor poderia apresentá-lo aos meus olhos, ou um segundo Vulcano entregá-lo em minhas mãos" (LESSING, 1964, p. 119). E conclui o elogio:

Eu não ficaria espantado se verificasse que um dos comentadores antigos de Homero admirara este trecho como a mais perfeita alegoria da origem, da continuação, do fortalecimento e, ao fim, da sucessão hereditária do poder real entre os homens. (Idem)

Para demonstrar melhor a força da ação, como ela atua alegoricamente para expor o poder de Agamêmnon, Lessing utiliza outra cena de Homero:

\begin{abstract}
Por este cetro que ramos nem folhas jamais, em verdade, reproduziu, dês que foi, na montanha, do tronco arrancado, e que jamais brotará, pois o bronze, de vez, arrancou-lhe a casca e as folhas - a vida - e que os filhos dos nobre Aquivos, quando em função de juízes, empunham, fazendo que valham as leis de Zeus e os preceitos - solene é, repito, esta jura! há de chegar o momento em que todos os nobres Aquivos hão de gritar por Aquiles, sem vires, então, nenhum modo de protegê-los, no tempo em que às mãos desse Heitor homicida uns sobre os outros caírem. (HOMERO, 2001, p. 64)
\end{abstract}

O profético discurso de Aquiles é reduzido por Lessing, pois só lhe interessa a comparação entre os cetros. Assim como há uma enorme diferença entre a história de um cetro e outro, assim acontece com relação ao poder de um e outro, como se observa no trecho a seguir:

A Homero não importava tanto descrever dois bastões de matéria e figuras diferentes, quanto proporcionar-nos uma imagem sensível da diversidade do poder que eles simbolizavam. Aquele, obra de Vulcano; este, cortado nos montes por mão desconhecida; aquele, antiga posse de uma nobre casa; este, destinado a guarnecer o primeiro punho a se apresentar; aquele, estendido por um monarca sobre muitas ilhas e sobre a Argólida inteira; este, portado por 
alguém do comum dos gregos, a quem foi confiada, juntamente com outros, a preservação da lei. Era esta realmente a distância entre Agamenon e Aquiles; uma distância que o próprio Aquiles, a despeito de seu cego furor, não podia deixar de admitir (LESSING, 1964, p. 120-1).

Priorizando, portanto, o tempo de ação (movimento), o autor consegue manter a atenção de seu leitor sobre os objetos em cena e utilizá-los mais do que simples ornamentos para a história, pois eles passam a carregar mais significados. É tendo como fundamento essas características que priorizam a temporalidade da ação que afirmamos que tanto Lessing quanto Weinrich voltam seus esforços para a comunicação. Essa, por sua vez, acontece na recepção da obra literária, sendo na verdade seu pressuposto temporal, já que ele só existe a partir do momento em que o leitor a lê: "[...] é pela leitura que se concretiza a função do tempo na narrativa, visto ser o destinatário da ficção que reatualiza o processo de reconfiguração do real que a obra literária de caráter épico cristaliza” (NUNES, 2002, p. 75).

A cena, que coloca ficticiamente o leitor no plano discursivo do presente da enunciação, é extremamente comunicativa. O processo comunicativo é encenado, segundo nossa interpretação a partir de Lessing, pelo tempo de ação (movimento), pois ele atrai a atenção do leitor. Além disso, com Weinrich, sabemos que as divisões gramaticais do tempo não são correlatas à da obra literária, já que há o tempo do texto (Textzeit), tão variado quanto o são as formas narrativas. Os tempos verbais possuem, considerando ainda a cena, o papel de estruturar o processo comunicativo entre o leitor e o texto:

\footnotetext{
Num ensaio polêmico intitulado Tempus, Harald Weinrich diz que a forma gramatical exerce função diferente da que os gramáticos pensaram conectando os tempos verbais às divisões do tempo. Em vez de enquadrarnos e localizarem as ocorrências numa dessas divisões, os tempos verbais situam o leitor ou o ouvinte no processo comunicativo da linguagem. (NUNES, 2002, p. 39) (grifo meu)
}

$\mathrm{O}$ ato de narrar ou contar põe em cena duas situações, sendo uma delas de locução narrativa e a outra de locução discursiva (locução de comentário). Nesse ponto estamos lidando com o narrar e o comentar. O interessante na teoria de Weinrich é relacionar esses recursos retóricos aos tempos verbais do texto ficcional. Assim, na situação de locução narrativa, estão os tempos verbais do pretérito perfeito, do imperfeito e do mais-que-perfeito; enquanto que na situação de comentário estão os do presente, do passado composto e do futuro (NUNES, 2002, p. 39-40). Na constituição 
do texto literário, essas duas modalidades de locução são fluidas e se interpenetram. $\mathrm{O}$ importante, quando lidamos com a elaboração de um romance ou uma epopeia, é saber que o pretérito não é, necessariamente, a descrição de fatos que aconteceram no passado, mas sim de que "há narrativa", como demonstra Benedito Nunes, exemplificando com Virgínia Woolf:

Se o pretérito tivesse esse compromisso com o passado, não se escreveriam nesse tempo as novelas de ficção científica e romances utópicos [...]. E dá-se também que o pretérito pode referir-se a uma situação presente, como na sequência do Orlando de Virgínia Woolf: "Na verdade, eram dez horas da manhã: Era o dia 11 de outubro. Era o momento presente" (NUNES, 2002, p. 40).

Desvinculando a ligação direta do pretérito com o tempo cronológico do passado, é possível dar um passo à frente e pensarmos diretamente na utilização dos tempos verbais na constituição da narrativa, na produção do discurso, tendo como base o ensaio Tempus, de Weinrich, analisado por Benedito Nunes. Resumindo a hipótese de um tempo do texto (Textzeit), o crítico brasileiro escreve:

O presente verbal denotaria o ponto zero de orientação no mundo comentado, como o pretérito no mundo narrado, enquanto os demais tempos firmariam, a partir daí, ora retrospectiva ora prospectivamente, uma perspectiva de locução. O imperfeito e pretérito perfeito permitiram variar a enfocação do conteúdo entre aspectos de primeiro plano, salientados pelo segundo, e aspectos de fundo, realçados pelo primeiro [...] (NUNES, 2002, p. 40)

Apresentada a hipótese de que os comentários e a narração constituem a temporalidade no discurso produzido pelo narrador, passaremos à última análise, que tratará da temporalidade da leitura. Esta possui, como iniciamos comparando Weinrich com Lessing, sua funcionalidade no processo comunicativo. A literatura produzida no século XX mostrou grande preocupação com o tema do tempo, porque, segundo Mendilow, essa era uma obsessão deste século e, assim, todas as formas de arte também a retrataram:

Quando as próprias maneiras de pensar e sentir trazem a marca da "obsessão do século XX pelo tempo" é de esperar que as formas de expressão artística também o façam. A preocupação pelo tempo revela-se em toda a arte, nos andamentos inquietos, ágeis e sincopados do jazz, e na libertação do acento da estrutura do compasso na música moderna. Está presente na busca dos poetas por ritmos mais livres em distinção aos padrões comparativamente fechados dos metros e estrofes tradicionais. Há artistas que tentaram veicular as impressões do tempo passando na pintura, isto é, do processo de 
movimento, não apenas do movimento aprisionado. (MENDILOW, 1964, p. 15)

Segundo o autor, a principal forma de arte que apresentou interesse pelo tema do tempo foi o romance que, "tendo iniciado sua carreira apenas no século XVIII" (MENDILOW, 1964, p. 15), possuía maior liberdade, pois "escapou aos efeitos inibidores de gerações de dogmas pela curta duração de sua carreira" (MENDILOW, 1964, p. 13). Assim, a artes temporais, que são caracterizadas por serem artes temáticas ou de representações, principalmente o romance do século XX, retratam os sentimentos e valores de uma determinada época, interpretando "para o povo as suas maneiras de comportamento e de pensar" (MENDILOW, 1964, p. 35). Por isso, segundo o autor de O tempo e o romance,

[...] os grandes escritores são aqueles que recusam aceitar como um ato cego de fé os padrões e crenças artísticas de seus predecessores; insistem em uma rigorosa revisão de toda a base da arte, começam de baixo, ao invés de tentarem ganhar uma estatura falsa firmando-se nos ombros de seus antecessores notáveis (Idem).

Poderíamos, como o crítico, citar diversos autores, mas para cumprir os objetivos de nosso estudo basta nos determos em dois: Laurence Sterne e Machado de Assis. Os dois autores claramente jogam com as formas de tempo em suas obras. Eles envolvem o tempo do ato de narrar, o tempo do ato de escrever e o tempo do ato de ler. Apresentando a forma então moderna de constituir o romance, Benedito Nunes diz que muito importou que

[...] o ato de escrita e o ato de leitura fossem visados como acontecimentos internos à criação ficcional, concorrendo com a história narrada. Um dos caminhos da autonomia artística de forma romanesca - conquista que não se fez num dia nem foi palmilhada em linha reta - , tal ocorrência teve em Sterne, no século XVIII, e em Machado de Assis, entre os séculos XIX e XX, os seus grandes promotores isolados. (NUNES, 2002, p. 53)

Em Vida e opiniões de Tristram Shandy, Sterne apresenta um narrador que atua como personagem e que, no momento em que começa a escrever, já se passaram quarenta anos de seu nascimento. Como resumo da técnica, é interessantíssimo o que apresenta Benedito Nunes (2002, p. 54):

Anunciando no capítulo 5 do volume I, o episódio do nascimento do narrador-personagem é interrompido por outros episódios, continuando no 
capítulo 8 do volume II, por motivos que o capítulo 6 do volume explica. [...] Ao chegar ao volume IV, já um ano mais velho do que há doze meses atrás, o narrador, que ainda não ultrapassara a narração de seu primeiro dia de vida, tem mais outro período de 364 dias para escrever:

"E como, neste passo, viverei 365 vezes mais depressa do que escrevo, segue-se, se vossas senhorias me permitem dizê-lo, que quanto mais escrevo, mais terei de escrever - e, por conseguinte, quanto mais vossas senhorias lerem, mais vossas senhorias terão de ler".

Irônico, o narrador demonstra sua técnica, tematizando o tempo de escrever com o de narrar e, por fim, o de ler, que é localizado num local indefinido do tempo, pois basta que qualquer leitor no futuro abra o livro.

Machado de Assis engendrou o tempo em sua obra, incluindo-o na própria estrutura da narrativa. Basta lembrarmos o romance que começa com a morte do autor fictício e a afirmação deste de que narrará a partir desse momento temporal, ou seja, a partir do tempo da morte, que no capítulo LXXI é assim definido por ele fazendo zombaria do leitor:

\footnotetext{
Começo a arrepender-me deste livro. Não que ele me canse; eu não tenho que fazer; e, realmente, expedir alguns magros capítulos para esse mundo sempre é tarefa que distrai um pouco da eternidade. Mas o livro é enfadonho, cheira a sepulcro, traz certa contração cadavérica; vício grave, e aliás ínfimo, porque o maior defeito deste livro és tu, leitor. Tu tens pressa de envelhecer, e o livro anda devagar; tu amas a narração direta e nutrida, o estilo regular e fluente, e este livro e o meu estilo são como os ébrios, guinam à direita e à esquerda, andam e param, resmungam, urram, gargalham, ameaçam o céu, escorregam e caem... (ASSIS, 1997, p. 112)
}

Caso Mendilow tivesse lido Memórias póstumas de Brás Cubas, teria farto material para complementar seu livro sobre o tempo e o romance. Sarcástico, o autor fictício engendra o leitor e o tempo em sua narração, produzindo um processo comunicativo extremamente rico e expressivo. Evidente que esse leitor produzido pelo discurso de Brás Cubas não é o empírico, pois há um espaço temporal entre o tempo do escritor e o tempo de leitura, que é diverso como o são os possíveis leitores dos tempos futuros a 1881. Esse é o leitor implícito que, segundo Wolfgang Iser, em seu livro $O$ ato da leitura, no volume 1 ,

tem existência real; pois ele materializa o conjunto das preorientações que um texto ficcional oferece, como condições de recepção, a seus leitores possíveis. Em consequência, o leitor implícito não se funda em um substrato empírico, mas sim na estrutura do texto. (ISER, 1996, p. 73) 
Esse leitor é uma entidade ficcional criada por recursos retóricos utilizados pelo autor para estabelecer uma identidade entre o discurso e seu interlocutor. Acertadamente, Hélio Guimarães, em seu estudo sobre o público machadiano no século XIX, O romance machadiano e o público de literatura no século $19^{11}$, analisa o leitor implícito, segundo as teorias da recepção de Wolfgang Iser:

\begin{abstract}
O interessante em Iser é o fato de ele estudar o leitor como entidade eminentemente ficcional e entender o texto literário como um processo que abrange "desde a reação do autor ao mundo até sua experiência pelo leitor" e procura investigar como esse leitor contemporâneo ao momento de produção está prefigurado pelo texto literário. [...] O sucesso do ato da interpretação dependeria, portanto, de um bom posicionamento do leitor em relação ao texto, posição que por sua vez estaria sugerida pelo próprio texto (GUIMARÃES, 2004, p. 42)
\end{abstract}

Posta a definição de leitor implícito, podemos averiguar a maneira como a sua temporalidade é engendrada no discurso do autor fictício. Para isso, utilizaremos o Capítulo VII - "O Delírio", do livro Memórias póstumas de Brás Cubas. Após ter contado o motivo de sua morte, uma pneumonia, ironizado pela ideia fixa da produção do Emplasto Brás Cubas, o autor fictício descreve a entrada de Virgília, no capítulo VI. Então, no VII, narra seu delírio, não sem antes uma introdução e nota de aviso ao leitor:

Que me conste, ainda ninguém relatou o seu próprio delírio; faço-o eu, e a ciência mo agradecerá. Se o leitor não é dado à contemplação destes fenômenos mentais, pode saltar o capítulo; vá direto à narração. $(M P$, p. 10)

Caso o leitor siga o conselho e pule o capítulo VII, achará no VIII ainda uma reflexão a partir do delírio contado no anterior. Com isso, o autor fictício é caracterizado por não ser confiável: ao expor suas escolhas narrativas, demonstra a arbitrariedade da escolha e da direção que constitui a sequência do que é narrado. Iniciando a descrição do delírio, ele afirma, após ter tomado a figura de um barbeiro chinês, transformar-se na Suma Teológica de São Tomás de Aquino:

Logo depois, senti-me transformado na Suma Teológica de S. Tomás, impressa num volume, e encadernada em marroquim, com fechos de prata e estampa; ideia esta que me deu ao corpo a mais completa imobilidade e ainda agora me lembra que, sendo as minhas mãos os fechos do livro, e cruzandoas eu sobre o ventre, alguém as descruzava (Virgília decerto), porque a atitude lhe dava a imagem de um defunto. (MP, p. 11)

\footnotetext{
${ }^{11}$ GUIMARÃES, Hélio de Seixas. Os leitores de Machado de Assis: o romance machadiano e o público de literatura no século 19. São Paulo: Nankin Editorial : Editora da Universidade de São Paulo, 2004.
} 
Há duas temporalidades neste trecho. A primeira é a do delírio e a segunda é a do presente de enunciação em que estão situados ficcionalmente Virgília, o autor fictício e o leitor implícito. Ao fazer com que suas mãos - fechos da Suma no tempo do narrado - sejam separadas por Virgília, o narrador transfere a temporalidade para o presente de narração. O jogo desses dois tempos, o do ato de contar e o do ato de comentar, surge novamente no final do capítulo, quando o hipopótamo que levou Brás Cubas para o início dos séculos começa a diminuir até chegar ao tamanho de um gato, que "era efetivamente um gato. Encarei-o bem; era o meu gato Sultão, que brincava à porta da alcova, com uma bola de papel..." (MP, p. 16).

Artifício retórico utilizado por Sterne em seu Tristram Shandy e que é emulado por Machado de Assis, esse jogo temporal incorpora o leitor na tessitura do texto. Interessante lermos a descrição que Benedito Nunes faz da técnica de Sterne:

\begin{abstract}
As anacronias em série de Vida e opiniões de Tristram Shandy complicamse, ainda, em decorrência do recorte do tempo cronológico pelo tempo vivido, que contrasta, por sua vez, com o tempo do ato de escrita, que contrasta com o presente da narração, que contrasta com a temporalidade do leitor... A essa zombaria do tempo, o narrador opõe as fintas do discurso, legitimando o seu relato pelo efeito humorístico da trama temporal de uma narrativa episódica "digressiva e progressiva" que, sem ter propriamente um enredo, enreda, conjuntamente, narrador e leitor (NUNES, 2002, p. 55).
\end{abstract}

Para a apreensão das digressões e progressões dos narradores, os leitores devem prestar atenção à narrativa que joga com os tempos, sendo necessária, para que o contrato entre autor e leitor se cumpra, a síntese memorial, que está presente no processo do ato de ler:

\footnotetext{
Seria errôneo entender a leitura, o ato e ler, como uma travessia puramente linear do texto. O percurso nas palavras, de linha a linha, não se limita a reproduzir, aditivamente, o enunciado das frases, dispostas em sequência. De frase a frase se opera uma sintese memorial, que retém os significados anteriores, e que, com base neles, propende aos seguintes. Uma reserva de "experiência conteudística e estilística" vai se acumulando à medida que se exerce, em cada nova frase, o mecanismo da experiência linguística (NUNES, 2002, p. 75).
}

A síntese memorial possui afinidade com a teoria da distentio animi (distensão da alma) que Agostinho utilizou para explicar o tempo, já que, ao começarmos a leitura de um salmo, por exemplo, que conhecemos de cor, antecipamos o futuro da leitura como expectativa do que será lido. Haveria uma reatualização do passado, que já não existe mais, tudo isso graças à atenção do leitor que conservaria o presente. 
Se estou para recitar uma canção que conheço, antes de começar, já minha expectativa se estende a toda ela. Mas, assim que começo, tudo o que vou destacando e entregando ao passado vai se estendendo ao longo da memória. Assim, a minha atividade volta-se para a lembrança da parte já recitada e para a expectativa da parte ainda a recitar; a minha atenção, porém, está presente: por seu intermédio, o futuro torna-se passado. E quanto mais avança o ato tanto mais se abrevia a espera e se prolonga a lembrança, até que esta fica totalmente consumida, quando o ato, totalmente acabado, passa inteiramente para o domínio da memória (AGOSTINHO, 2006, p. 359-60).

A semelhança com o ato de leitura é a atenção que o leitor deve depreender para partilhar do contrato de leitura estabelecido por um texto que não é narrado em linha reta, como disse o autor fictício de Machado de Assis. Lembrando, para finalizarmos, que toda narrativa se faz por ações, movimento, das personagens e que, portanto, é possível narrar o tempo, que é o assunto do livro A montanha mágica, como nos afirma o seu narrador:

[...] uma vez que é possível "tratá-lo", é lógico que o tempo, além de ser o elemento da narrativa, também pode tornar-se o seu assunto. Embora seja exagero afirmar que se pode "narrar o tempo", não constitui certamente empresa tão absurda, como nos parecia de início, a de querer narrar coisas do tempo. Destarte poderíamos atribuir uma singular ambiguidade de sonho ao conceito de um "romance do tempo". Com efeito, ventilamos o problema de saber se é possível ou não narrar o tempo exclusivamente para confessar que, na presente história, temos coisa semelhante em mente. (MANN, 2002, p. 741)

Enquanto o narrador de Thomas Mann confessa o objetivo de escrever um "romance do tempo", nos próximos dois capítulos, que constituem nossa análise, temos como objetivo demonstrar como as coisas do tempo foram engendradas na obra Grande Sertão: Veredas, de João Guimarães Rosa, visto que ela não versa sobre o tempo como a do escritor alemão. 


\section{Capítulo 2: COISAS do TEMPo}

Aquilo era como fosse um touro preto, sozinho surdo nos ermos da Guararavacãa, urrando no meio da tempestade. (GS:V, p. 270)

Este capítulo, cujo título é tomado ao livro $A$ montanha mágica, de Thomas Mann (2002, p. 741), divide-se em duas partes. A primeira, chamada “Época literária", ocupa-se da literatura brasileira antes da publicação de Grande Sertão: Veredas em 1956, tratando de alguns aspectos literários do regionalismo e do modernismo para discutir como Guimarães Rosa os transforma quando produz sua obra. Além disso, determina-se a posição de escritores quanto à sua arte, posição que, no caso do autor mineiro, é extremamente importante em termos de um projeto literário consciente, como ele evidencia em entrevistas, em sua correspondência e em sua ficção. O objetivo é mostrar como sua preocupação com a linguagem associa-se intimamente à sua produção literária.

A segunda parte, denominada "As formas do tempo no Grande Sertão: Veredas", é uma exposição a respeito do modo como o tempo é figurado nesse romance. Para figurar o tempo, o autor vale-se de diversos procedimentos retóricos que exploram ao máximo o potencial significativo da palavra. No caso, refere-se também o modo como a animização de elementos naturais, como o rio, o buriti, o vento, é um procedimento de temporalização que figura sentimentos, acontecimentos futuros, momentos de paz e tranquilidade. Esse caráter da obra é reforçado porque Grande Sertão: Veredas é, como propõe Cavalcanti Proença, um romance telúrico.

\section{Época literária}

Maio de 1956: Grande Sertão: Veredas

Guimarães Rosa surge como autor na literatura brasileira em 1937, com a primeira versão de Sagarana. É nesse ano que o escritor regional mineiro reinventa o regionalismo, que teve seu ponto mais alto com José Lins do Rego (Usina e Fogo Morto) e Graciliano Ramos (Vidas Secas), com o sentido que iremos discutir mais 
adiante. Certamente houve vários outros autores que se dedicaram à catalogação de costumes, palavras, histórias de suas regiões, mas a falta de engenho ao lidar com o material não lhes permitiu escrever obras esteticamente boas e não foram consagrados. Quando Sagarana sai do prelo, em 1937, o regionalismo estava desgastado e desacreditado pelas experiências falhadas dos escritores das décadas de 30. Sagarana, primeiro livro de Rosa, já sobressai, frente à estereotipação de grande parte da prosa regionalista, como obra de um autor diferente. Tristão de Ataíde define a entrada de Guimarães Rosa nas letras brasileiras do seguinte modo:

Entrava, como Euclides da Cunha, sem mansidão nem violência, mas de corpo inteiro, com uma obra feita, à qual nada faltava para lhe garantir um lugar à parte na galeria dos nossos grandes criadores. (ATAÍDE, 1991, p. 142)

Se é verdade que Guimarães Rosa se dá de "corpo inteiro" à sua arte de escrever, sua entrada no campo literário não é como a de um Euclides da Cunha; tampouco Sagarana é obra acabada. A respeito desses dois pontos, Luiz Roncari, no livro O Brasil de Rosa, define o que considera ser uma "primeira fase" do autor:

Foi o meu propósito estudar apenas os livros que compõem o que chamo de “o primeiro Guimarães": Sagarana, Corpo de baile e Grande ertão: veredas. O que lhes dá unidade é o fato de terem sido escritos durante o período do "desenvolvimento getulista", quando o país passou por importantes transformações econômicas, mas também viveu grandes indefinições institucionais. (RONCARI, 2004, p. 13)

Comentando como irá desenvolver seu estudo, Roncari diz que "Sagarana era um livro excelente, tanto pelas boas realizações, como pelos defeitos de acabamento de certas passagens, ainda um tanto toscas, que deixavam mais expostos os travejamentos e, desse modo, explicitavam o seu método de composição" (idem, p. 18). Com isso, demonstra que nesse primeiro livro ainda havia muito de experimentação:

Guimarães estava experimentando nesse livro várias formas arcaicas da narrativa, como as do Contos da cantuária, da picaresca, do fabulário, das vidas dos santos, dos causos. Ao mesmo tempo, percebia-se que ele acompanhava todos os avanços da literatura moderna, num contexto literáriocultural como o brasileiro, que reagia ainda aos tumultos causados pelos movimentos modernistas. (idem, p. 15)

A respeito desse acompanhamento, Willi Bolle defende a hipótese de que Grande Sertão: Veredas é uma reescrita de Os sertões, de Euclides da Cunha. Baseando 
sua hipótese em estudos sobre a formação do Brasil, Bolle recorre a teóricos atuantes entre as décadas de 1930 e 1990, como Gilberto Freyre, Sérgio Buarque de Holanda, Caio Prado Jr., Celso Furtado e Darcy Ribeiro. Para Bolle, assim como para Roncari, o autor brasileiro constitui sua obra a partir da leitura crítica do que tinha sido feito, desde os "tumultos" modernistas até seu desenvolvimento do que estava em germe no tratado sociológico de Euclides, já que Rosa evidentemente o leu:

Tal especulação não deixa de se apoiar no estudo de fontes. Durante a fase preparatória do seu romance, Guimarães Rosa releu devidamente a obra principal de Euclides da Cunha, como atestam as marcas de leitura em seu exemplar de Os Sertões. (BOLLE, 2004, p. 27)

Comentando uma conversa de Guimarães Rosa num encontro de vaqueiros na cidade de Cipó, em 1952, Bolle afirma:

O romancista realça no autor de Os Sertões um feito pioneiro: ter substituído a visão pitoresca que tiveram do sertanejo os naturalistas e regionalistas por uma visão histórica. (idem, p. 28-9)

Apesar de render homenagem a Euclides, Guimarães Rosa se distancia muito do estilo dele na elaboração de sua obra. A diferença mais importante é seu distanciamento em relação à grandiloqüência do narrador euclidiano:

Na leitura de Os Sertões por parte de Guimarães Rosa nota-se um acentuado interesse técnico pela pesquisa de determinadas palavras e uma atitude impassível diante das frases euclidianas de efeito, uma observação "fria" da retórica do páthos e da comoção. (idem, p. 28)

Tratando do narrador de Grande Sertão: Veredas, Hansen propõe a diferença existente entre seu estilo paródico e o que até então se via nos textos regionalistas da literatura brasileira:

Este pôr em cena das linguagens - as do sertão, imediatamente e as das representações que os códigos ilustrados fazem do sertão, mediatamente, sem que se fale dos estilemas e filosofemas de procedência variadíssima, da tradição ocidental e oriental - tal encenação, enfim, situa pelo avesso, no vazio de uma fala e de um sujeito ainda não constituídos, aquilo que ainda não falou diretamente: o "sertão". Pela primeira vez em nossa literatura, o sertão irrompe como discurso sábio: imagine-se, com humor, o Conselheiro interpretando a vida de Euclides da Cunha ou Roberto do Diabo escrevendo um lai sobre os roubos dos banqueiros de São Paulo. (HANSEN, 2000, p. 33) 
É a voz de uma reinvenção do regionalismo, que não se limita a representar particularidades físicas e sociais da região como um apanhado de palavras e costumes canhestros que caracterizariam a prática literária de "muitos escritores fracos", como diz Paulo Rónai, em 1946, a respeito do regionalismo antes de Sagarana:

Para muitos escritores fracos, o regionalismo é uma espécie de tábua de salvação, pois têm a ilusão - e com eles parte do público - de que o armazenamento de costumes, tradições e superstições locais, acúmulo de palavras, modismos e construções dialetais, a abundância da documentação folclórica e linguística suprem as falhas da capacidade criadora. (RÓNAI, 2001, p. 15)

$\mathrm{Na}$ época da publicação do primeiro livro de Rosa, o regionalismo era antes um empecilho que algo positivo, pois mais dificultava que favorecia o surgimento de um grande escritor, visto o desgaste que já havia sofrido. Mas isso parece não preocupar o autor mineiro, porque, como se lê em uma carta dele a João Condé, escreve para transmitir sua "concepção-do-mundo":

\begin{abstract}
Assim, pois, em 1937 - um dia, outro dia, outro dia... - quando chegou a hora de o Sagarana ter de ser escrito, pensei muito. Num barquinho, que viria descendo o rio e passaria ao alcance das minhas mãos, e eu ia poder colocar o que quisesse. Principalmente, nele poderia embarcar, inteira, no momento, a minha concepção-do-mundo. (ROSA, 2001, p. 23-4)
\end{abstract}

Fazendo essa afirmação, segue dizendo que precisa escolher o local em que ambientar suas histórias adultas da Carochinha:

Àquela altura, porém, eu tinha de escolher o terreno onde localizar as minhas histórias. Podia ser Barbacena, Belo Horizonte, o Rio, a China, o arquipélago de Neo-Baratária, o espaço astral, ou, mesmo, o pedaço de Minas Gerais que era mais meu. E foi o que preferi. (ROSA, 2001, p. 25)

Essa indeterminação da localização geográfica e nacional das histórias associase diretamente à resposta que dá na entrevista que em Gênova, em 1964, concedeu ao crítico alemão Günter Lorenz. Quando este lhe pergunta se seu "caráter literário" o inclui no grupo de autores denominados "regionalistas", Rosa responde:

Sim e não. É necessário salientar pelo menos que entre nós o "regionalismo" tem um significado diferente do europeu [...] Naturalmente não gostaria que na Alemanha me considerassem um Heimatschriftsteller. Seria horrível, uma vez que é para você o que corresponderia ao conceito de "regionalista". Ah, a dualidade das palavras! Naturalmente não se deve supor que quase toda a literatura brasileira esteja orientada para o "regionalismo", ou seja, para o 
sertão ou para a Bahia. Portanto, estou plenamente de acordo, quando você me situa como representante da literatura regionalista; e aqui começa o que eu já havia dito antes: é impossível separar minha biografia de minha obra. (ROSA, 1991, p. 66)

O regionalismo de Rosa é diferente, porque suas histórias, que têm como fundamento a experiência do autor com a região que é referência de sua arte, sintetizam valores universais, como propôs Antonio Candido no ensaio "O homem dos avessos", de 1957:

A experiência documentária de Guimarães Rosa, a observação da vida sertaneja, a paixão pela coisa e pelo nome da coisa, a capacidade de entrar na psicologia do rústico, - tudo se transformou em significado universal graças à invenção, que subtrai o livro à matriz regional para fazê-lo exprimir os grandes lugares comuns, sem os quais a arte não sobrevive: dor, júbilo, ódio, amor, morte, - para cuja órbita nos arrasta a cada instante, mostrando que o pitoresco é acessório e que na verdade o Sertão é o Mundo. (CANDIDO, 1971, p. 122)

Talvez uma das contribuições mais importantes desse ensaio de Antonio Candido seja a noção de "universalismo" que identifica na obra rosiana a partir do seu regionalismo: "o Sertão é o Mundo". Mas também não se pode esquecer que a inventio do autor mineiro é o grande diferencial entre ele e seus antecessores:

Há em Grande Sertão: Veredas, como n'Os Sertões, três elementos estruturais que apoiam a composição: a terra, o homem, a luta. Uma obsessiva presença física do meio; uma sociedade cuja pauta e destino dependem dele; como resultado o conflito entre os homens. Mas a analogia para aí; não só porque a atitude euclidiana é constatar para explicar, e a de Guimarães Rosa inventar para sugerir, como porque a marcha constante dos três elementos, refugindo a qualquer naturalismo e levando, não à solução, mas à suspensão que marca a verdadeira obra de arte, e permite a sua ressonância na imaginação e na sensibilidade. (CANDIDO, 1971, p. 123)

Como nos lembra Willi Bolle, na comparação feita por Antonio Candido deve-se considerar principalmente a liberdade de inventar de Guimarães Rosa:

[...] ele [Antonio Candido] também insistiu na diferença entre os dois autores, realçando "as leis próprias do universo de Guimarães Rosa" - autor que "escapa aos hábitos realistas" e que tem seu espaço fundamental na "liberdade de inventar". (BOLLE, 2004, p. 24-5)

Entre as classificações de "regionalista" e "universalista", vale a pena ler mais uma, agora de Tristão de Ataíde: 
Mas nada é mais estranho à sua literatura do que o regionalismo. Será sertanista mas não regionalista. É todo o interior do Brasil, e não apenas os "sertões do Urucúia", por suas paisagens, suas criaturas humanas, seus costumes e sua linguagem, que vive em seus romances e suas novelas. Nunca limitado a uma região, sendo embora mineiro de nascimento e até de espírito, não é como tal que criou talvez um gênero em nossas letras e forjou seguramente uma linguagem. (ATAÍDE, 1991, p. 143)

Essa última - a invenção de uma linguagem nova - é acertada, pois Guimarães Rosa trabalhava ao máximo a forma, explorando e extrapolando, quando necessário, as relações entre significante e significado para alcançar seus objetivos de comunicação de uma língua literária nova. Por outro lado, praticamente toda a sua obra e principalmente seu único romance se passam nas regiões da Bahia, Goiás e Minas Gerais. Talvez seja exagero afirmar que criou um gênero. Mas é certo que inventou um estilo singular, único e inimitável, pois copiá-lo é lançar-se ao ridículo da macaqueação.

Com essa definição, com base nos textos de seus antecessores e, talvez mais do que todos, na obra de Machado de Assis (que abordaremos no terceiro capítulo desta dissertação), Guimarães Rosa lança, em maio de 1956, alguns meses depois de lançar Corpo de baile, o romance Grande Sertão: Veredas. Duas obras de fôlego, como se diz. A preocupação do autor é com a qualidade de suas obras, pois ele as tomava como uma missão, como diz a Lorenz:

Veja, nós, os escritores, somos uma raça realmente estranha, e eu certamente o mais estranho deles todos. Tem razão; não estou me elogiando, quando digo que trabalho duro e aplicadamente. Mas lamento que, apesar de todo meu empenho, trabalhe muito lentamente. Sem dúvida, comecei a escrever no tempo certo, mas demasiadamente tarde. Apesar de ser verdade, isto também é um paradoxo. Não me posso permitir uma morte prematura, pois ainda trago dentro de mim muitas, muitíssimas estórias. (ROSA, 1991, p. 72)

O homem João Guimarães Rosa, diplomata, não dependia do dinheiro de seus livros para viver, o que faz muita diferença, pois, como ele mesmo afirma, trabalha muito lentamente. Schopenhauer, no seu livro Sobre o ofício do escritor, é categórico quando fala sobre literatura e dinheiro:

As obras mais primorosas dos grandes homens são todas da época em que eles ainda tinham de escrever de graça ou por honorários muito reduzidos. [...] O estado deplorável da literatura hodierna, na Alemanha e no exterior, tem na sua raiz o fato de se ganhar dinheiro escrevendo livros. Todo aquele que precisa de dinheiro senta-se à escrivaninha e põe-se a escrever um livro, e o público é suficientemente tolo para comprá-lo. A consequência secundária disso é a deterioração da língua. (SCHOPENHAUER, 2003, p. 4-5) 
Perguntado por Lorenz sobre sua obra e o dinheiro, que na entrevista passa pelo crivo das questões escritor/política, escritor/deslealdade, Guimarães Rosa responde:

[...] não me envergonho em admitir que Grande Sertão me rendeu um montão de dinheiro. Não me interessa o dinheiro: venho de um mundo onde ele não adianta muito; lá se necessita de pão, armas, cavalos, e ainda se pratica o comércio de troca. [...] Não necessito dele, tenho meus vencimentos. (ROSA, 1991, p. 78-9)

O que importa a Guimarães Rosa é o trato com a língua. Não só a língua portuguesa, mas todas as que conhecia:

Escrevo, e creio que este é o meu aparelho de controle: o idioma português, tal como o usamos no Brasil; entretanto, no fundo, enquanto vou escrevendo, eu traduzo, extraio de muitos outros idiomas. Disso resultam meus livros, escritos em um idioma próprio, meu, e pode-se deduzir daí que não me submeto à tirania da gramática e dos dicionários dos outros. (idem, p. 70)

A expressão por meio da palavra é a maior fixação do autor. Como exemplo, veja-se o início de Grande Sertão: Veredas:

- Nonada. Tiros que o senhor ouviu foram de briga de homem não, Deus esteja. Alvejei mira em árvore, no quintal, no baixo do córrego. Por meu acerto. Todo dia isso faço, gosto; desde mal em minha mocidade. ( $G S: V$, p. 5)

A primeira palavra do livro ("nonada") pode ser lida como um nome, um pronome substantivo, um advérbio e uma predicação, como propõe Hansen:

[...] pode-se traduzir o significado de "nonada" como se o signo fosse um nome: "o nada", "coisa alguma"; como um pronome substantivo: "nada"; como um advérbio: "em lugar algum", "em parte alguma", "no nada"; como uma predicação: "algo não é coisa alguma", "isso é nada", "algo é no nada", "algo é nada" [...] ( HANSEN, 2000, p. 43)

Essa diversidade de leituras evidencia como Guimarães Rosa evita apriorismos lógicos e categóricos, sejam eles gramaticais, de gênero, de forma. Para conseguir o máximo de significação e sentido da palavra, ele explora a relação entre forma e conteúdo inventando uma forma literária nova, que ao mesmo tempo em que fixa particularidades regionais, integra-as em outros níveis metafóricos ou alegóricos de significação mitológica, metafísica e literária. Eles passam a conotar idéias universais, como diz Hansen no ensaio "Forma, indeterminação e funcionalidade das imagens de Guimarães Rosa", retomando a idéia exposta por Antonio Candido de que Rosa, 
diferentemente de Euclides, descreve para sugerir. A recategorização gramatical, recurso muito utilizado pelo autor, visa à substantivação sugestiva de verbos ou advérbios, por exemplo, e tem a dupla consequência de tornar seu texto "dinamicamente expressivo". A escrita imita ritmos da oralidade, característica fundamental de Grande Sertão: Veredas. Veja-se, a propósito, o seguinte trecho de Mary Lou Daniel:

\begin{abstract}
Ainda que a substantivação de elementos tão diversos como advérbios, preposições e verbos possa dar ao leitor impressão de que o autor está criando efeitos inusitados à custa da correção gramatical, é preciso admitir que por meio deste recurso ele abre novas perspectivas na flexibilidade dos substantivos. $\mathrm{O}$ aproveitamento de tais formas traz à categoria nominal, tradicionalmente estática, novos conceitos espaciais, temporais e modais e lhe infunde um espírito dinamicamente expressivo que não deixa de captar a imaginação do leitor e até expandir esta no processo de rompimento dos compartimentos gramaticais (DANIEL, 1968, p. 86).
\end{abstract}

A Günter Lorenz o autor demonstra que se utiliza do paradoxo para conseguir o efeito de estranhamento e de maiores possibilidades de indeterminação do sentido:

Os paradoxos existem para que ainda se possa exprimir algo para o qual não existem palavras. Por isso, acho que um paradoxo bem formulado é mais importante que toda a matemática, pois ela própria é um paradoxo, porque cada fórmula que o homem pode empregar é um paradoxo. (ROSA, 1991, p. 68)

O paradoxo é base para dizer o que ainda não foi dito e também meio pelo qual o escritor pode contemplar objetivamente o incompreensível. Ele serve de ferramenta para o autor apontar o "infinito" 12 que almeja atingir, mas sem intimidade:

O escritor deve se sentir à vontade no incompreensível, deve se ocupar do infinito, e pode fazê-lo não apenas aproveitando as possibilidades que lhe oferece a ciência moderna, mas também agindo ele mesmo como um cientista moderno. Não se pode tratar o infinito com intimidade, nem com subjetivismo. É preciso ser objetivo, pois o incompreensível pode, pelo menos, ser contemplado objetivamente. Não, não, o autor não pode se permitir intimidades em sua obra. A poesia é também uma irmã tão incompreensível da magia. (idem, p. 89)

A magia, o incompreensível, a terceira margem das "coisas" são apreensíveis, portanto, por meio do paradoxo e da objetividade, já que Guimarães Rosa nega a intimidade. Com isso, a própria técnica do autor é paradoxal, já que a contemplação é objetiva, mas se dá pelo paradoxo, que pressupõe a afirmação de dois sentidos

\footnotetext{
${ }^{12} \mathrm{O}$ último signo de Grande Sertão: Veredas é o do infinito $(\infty)$.
} 
contraditórios como simultaneamente válidos, isto é, como uma "lógica toda sua"13. Eis o jogo do qual se vale o autor para inventar sua obra, desde os contos de Sagarana até o livro póstumo, Ave, Palavra. Com o paradoxo, Guimarães Rosa produz o efeito de indeterminação, utilizando-o como "procedimento técnico e poético", como propõe Hansen no seu ensaio "Forma, indeterminação e funcionalidade das imagens de Guimarães Rosa":

A negação da "lógica" é, contudo, procedimento técnico e poético também comunicado funcionalmente como avaliação da forma. Rosa insiste na superioridade artística da enunciação por paradoxos que afirmam dois sentidos contrários simultaneamente válidos por oposição à enunciação "lógica", que pressupõe a contradição e o princípio do $3^{\circ}$ excluído como critérios de determinação da verdade e verossimilhança. (HANSEN, 2007, p. 38)

A linguagem de Guimarães Rosa é produzida pressupondo a negação da lógica aristotélica e cartesiana, reforçando o princípio poético que rege sua técnica. A chamada “álgebra mágica”, ou língua pré-babélica, constitui-se em pensar a palavra como sentido e som:

Sou precisamente um escritor que cultiva a ideia antiga, porém sempre moderna, de que o som e o sentido de uma palavra pertencem um ao outro. Vão juntos. A música da língua deve expressar o que a lógica da língua obriga a crer. Nesta Babel espiritual de valores em que hoje vivemos, cada autor deve criar seu próprio léxico, e não lhe sobre nenhuma alternativa; do contrário, simplesmente não pode cumprir sua missão. (ROSA, 1991, p. 88)

O som é representado pela escolha muito deliberada das palavras que se seguem na oração. A sonoridade de um vocábulo ressoa na do seguinte, figurando o que não é significado expressamente no livro. Para esclarecer esse ponto, vejamos a cena do pacto nas Veredas Mortas:

Viesse, viesse, vinha para me obedecer. Trato? Mas trato de iguais com iguais. Primeiro, eu era que dava a ordem. E ele vinha para supilar o ázimo do espírito da gente? Eu era eu - mais mil vezes - que estava ali, querendo, próprio para afrontar relance tão desmarcado. Destes meus olhos esbarrarem num rôr de nada. (GS:V, p. 383-4) (grifos meus)

\footnotetext{
${ }^{13}$ Mary L. Daniel mostrou, de forma muito arguta, como a pontuação é uma característica muito particular da obra de Guimarães Rosa: "Uma das mais válidas generalizações que se podem fazer a respeito da pontuação rosiana é aquela empregado por Ernesto da Cal com referência ao mesmo aspecto da prosa de Eça de Queirós: "La puntuación... no es ortográfica, sino estética, literaria." No caso de Guimarães Rosa, porém, esta última palavra bem podia modificar-se em oral. O leitor que procurar interpretar a narrativa do autor em têrmos das tradicionais convenções de pontuação fica imediatamente frustrado, uma vez que o sistema rosiano tem uma lógica tôda sua" (1968, p. 117).
} 
Percebem-se os grupos de sonoridade que iniciam o período e como eles se repetem em determinados pontos, sempre reforçando e retomando o som que os precede. Fala, neste trecho, a voz da noite representada pelo som sibilante do vento; contudo, em nenhum momento se diz ou descreve-se o som do vento. Os /v/ que começam o parágrafo e são repetidos no meio dele ("vezes" e "estava"), junto aos sons dos /s/ e /z/ ("viesse", "iguais", “ázimo" etc), simbolizam, além do som do vento, a atmosfera sombria que constitui a cena. Isso vem reforçado pelos diversos $/ \mathrm{r} /$, principalmente nos encontros consonantais ("trato", "primeiro", "próprio"). Vale ressaltar que, para além desse mero parágrafo tomado como exemplo, a mesma aliteração de sons surge em toda a cena do pacto.

Outro exemplo desse método pode ser verificado na criação do neologismo "luava", também remetendo à noite: "Vão da noite, quando o mato pega a adquirir rumores de sossegação. Ou quando luava, como nos Gerais dá, com estrelas ( $G S: V, \mathrm{p}$. 497)". A formação de "luava" tem sua raiz na construção de verbos a partir de substantivos: amor $=$ amava; choro $=$ chorava; lua $=$ luava. Aqui, pelo contexto, nota-se a diferença com a cena do pacto. Embora surjam os /s/ sibilantes, a atmosfera remete à tranquilidade, sendo que "luava", com suas três vogais, transmite a continuidade da ação da lua que a tudo cobre com sua luz pálida, propícia à paz do momento amoroso que Riobaldo divide com Diadorim. Em outras palavras, mais do que sugerir o som da noite empírica, o neologismo é um correlato objetivo que figura sugestivamente sentimentos do protagonista.

Apenas para ilustrar, lembramos um relato de Décio Pignatari sobre a prosa de Guimarães Rosa. Segundo ele, em conversa que teve com Rosa, este afirmou que a prosa brasileira era muito "boca-mole", "frouxa", associando essas qualidades negativas à sua falta de "caráter": "É uma prosa muito boca-mole, não tem caráter. Eu gosto mais de uma pedra pedregosa, de uma prosa pedregosa" ${ }^{\text {"14 }}$. Curioso com tal afirmação, Décio pergunta o que era uma prosa boca-mole, ao que Guimarães Rosa esclarece: "Quase metade de toda e qualquer prosa feita no Brasil é feita de vogais" ${ }^{\prime 15}$. Informado disso, Pignatari fez uma pesquisa em alguns textos de Guimarães Rosa e depois lhe disse: "Ela [a prosa] é mais pedregosa porque ela tem mais consoantes do que o normal. Você [Guimarães Rosa] usa muito trigramas tipo str, enquanto que a tendência brasileira é

\footnotetext{
${ }^{14}$ Entrevista aqui transcrita a partir do DVD que saiu junto à Edição Comemorativa de 50 anos de Grande Sertão: Veredas.

${ }^{15}$ Idem.
} 
quase que uma consoante para uma vogal" ${ }^{16}$. Em uma rápida busca realizada no romance Grande Sertão: Veredas ${ }^{17}$ pelas palavras que possuem a sequência str, verificamos 539 incidências em 608 páginas. Apenas para sugerir, queremos mostrar que o autor não separa forma e conteúdo; sendo assim, a simples referência às 539 ocorrências não têm muita significação quando a ocorrência é isolada. No entanto, quando as ocorrências ressoam umas nas outras, é o contexto do seu uso, como no exemplo da cena do pacto, que evidencia que constituem um belo método de sugestão aplicado para expressar o que não é dito, ou, como nos diz Rosa, o interdito, o entredito e o supradito.

Essa elaboração trabalhadíssima da escritura faz de Guimarães Rosa um grande autor porque, além de pensar sua arte como missão e pôr um empenho gigantesco na sua realização, leva em conta a tradição literária, redefinindo seus padrões. Por isso, causa estranhamento até hoje, apesar de aceito como um dos melhores autores da literatura brasileira. Vale a pena, assim, ressaltar a importância da relação de Guimarães Rosa com o regionalismo e, principalmente, com a geração do modernismo, como faz Wilson Martins ao avaliar os elementos do romance Grande Sertão: Veredas:

Realmente, importava muito "ponderar" os diversos elementos do romance, de forma a não superestimar, como uma parte da crítica brasileira, alguns dos seus aspectos mais salientes ou atrativos, em detrimento de outros; convinha, particularmente, marcar desde logo que se trata de um romance regionalista de alcance universal, pois era isso, justamente, que o inseria na tradição da literatura brasileira e, mais especificamente, na tradição do Modernismo. (MARTINS, 1968, p. XV)

Segundo Martins, Rosa continua a tradição literária, superando problemas artísticos, como o esteticismo, que o modernismo não tinha conseguido resolver totalmente:

Com efeito, apesar das aparências, Guimarães Rosa não rompe com a tradição literária do seu país, nem poderia ser grande escritor se o fizesse: sua obra define-se como a tentativa, não raro bem sucedida e sempre, de qualquer forma, extremamente original, de superá-la e prolongá-la pela inclusão num processo espiritual e intelectual de outra ordem; contudo, parece inegável que essa obra não teria sido o que foi se o Modernismo não tivesse, algo atabalhoadamente, mostrado os caminhos possíveis. Entre eles estava o esteticismo, que era um dos impulsos mais profundos da escola, mas que os modernistas da primeira faze sufocavam violentamente dentro de si mesmos. (idem, p. XV)

\footnotetext{
${ }^{16}$ Ibidem.

${ }^{17}$ Aqui, para facilitar, utilizamos a edição disponibilizada pela editora Nova Fronteira em formato PDF na internet em comemoração aos 50 anos de Grande Sertão: Veredas.
} 
O objetivo, neste subcapítulo, foi comentar como Guimarães Rosa não só enfrentou um empecilho (o regionalismo), em prol de escrever a partir daquilo que the era familiar, como - tendo por base o desenvolvimento de "um idioma" seu, como ele mesmo disse - inventou um estilo, o estilo Guimarães Rosa, que não ignorou a literatura que se fez anteriormente, mas afirmou a liberdade desejada pelo autor.

\title{
As formas do tempo na obra Grande Sertão: Veredas
}

\author{
Tempo que me mediu. Tempo? Se as pessoas \\ esbarrassem, para pensar — tem uma coisa! —: eu \\ vejo é o puro tempo vindo de baixo, quieto mole, como \\ a enchente duma água... Tempo é a vida da morte: \\ imperfeição. Bobices minhas — 0 senhor em mim não \\ medite. (p. 535).
}

No romance de Guimarães Rosa aparecem algumas referências a eventos de um tempo histórico real. Uma delas diz respeito à passagem da Coluna Prestes, que vinha de Goiás:

\footnotetext{
Os revoltosos depois passaram por aqui, soldados de Prestes, vinham de Goiás, reclamavam posse de todos animais de sela. Sei que deram fogo, na barra do Urucúia, em São Romão, aonde aportou um vapor do Governo, cheio de tropas da Bahia. Muitos anos adiante, um roceiro vai lavrar um pau, encontra balas cravadas. (GS:V, p. 88)
}

Indo para o Norte do Brasil, a Coluna Prestes chega a Goiás em junho de 1925. Após combate na Fazenda Zeca Lopes contra os soldados do major Klinger é que ela marcha para o Norte, como lemos no livro da historiadora Anita Leocádia Prestes, Uma epopeia brasileira: a Coluna Prestes:

Em 29 de junho de 1925, ao acampar na Fazenda Zeca Lopes, o comando da Coluna recebeu a segunda carta de Klinger. O oficial intimava os rebeldes à rendição e oferecia-lhes garantias de vida, o que eles encararam como um insulto.(PRESTES, 1995, p. 70)

Os revoltosos são atacados e, indignados com o comportamento dos governistas, resolvem combatê-los. Frente ao grande poder de fogo dos soldados de Klinger, a 
Coluna avança para o Norte, ainda adotando a tática da "guerra de movimento", o que impediu que fosse derrotada e fez sua fama:

Ao norte de Anápolis, Klinger, cumprindo ordens superiores, ainda tentou destroçar os rebeldes. Mas caiu numa emboscada e perdeu dois dos seus caminhões, com os quais os rebeldes fizeram uma fogueira, pondo os soldados governistas para correr. Impossibilitado de perseguir os revolucionários pelas estradas de rodagem, uma vez que a Coluna se embrenhou pelas matas, Klinger acabou desistindo de combatê-los. Foi mais uma vitória da Coluna Prestes e da sua tática de "guerra de movimento". (PRESTES, 1995, p. 73)

Em seguida, a historiadora retrata a chegada da Coluna ao rio Urucúia e o retorno dos rebeldes para Goiás, visto não terem condições de vencer os policiais baianos a serviço do Governo:

\begin{abstract}
Após a retirada de Klinger da campanha militar, os rebeldes marcharam com relativa tranquilidade rumo ao Norte-Nordeste. A Coluna desviou-se para leste, atravessando o vão profundo do Rio Paraná e seguindo pela margem do Rio Urucúia, já em Minas Gerais. Visava chegar ao Rio São Francisco e, quem sabe, atravessá-lo, na tentativa de ameaçar Belo Horizonte e, se houvesse condições, marchar sobre o Rio de Janeiro. Logo a inviabilidade desse projeto ficou evidente - havia muitos policiais baianos, mobilizados pelo governo, navegando por aquele trecho do São Francisco e os rebeldes não dispunham de armamento suficiente para enfrentá-los.

Diante disso, a Coluna recuou e, após atravessar o Rio Carinhanha e marchar por uma pequena faixa do território baiano, voltou a penetrar em Goiás, dirigindo-se para o norte. (idem, p. 73)
\end{abstract}

Outra referência histórica é a contada pelo pai/padrinho do narrador, Selorico Mendes. Agora, trata-se da tomada de portos da bacia do Rio São Francisco por um chefe de jagunços, Neco, no ano de 1879:

Demais falasse, tendo conhecido o Neco, se lembrava de quando Neco forçou Januária e Carinhanha, nas éras do ano de 79: tomou todos os portos Jatobá, Malhada e Manga - fez como quis; e pôs séde de suas fortes armas no arraial do Jacaré, que era a terra dele (GS:V, p. 101).

No seu livro O rio São Francisco e a Chapada Diamantina, Teodoro Sampaio relata o ambiente de guerra que se instaurou:

[...] por uma questão política, a gente da Januária entrou em luta encarniçada, uma parcialidade contra outra, valendo-se de ódio velho e de muita intriga como sói acontecer nesses sertões apartados. O grupo ou parcialidade que não tinha por si as autoridades retirou-se rio abaixo e veio fazer seu quartel general no lugar Jacaré, onde Neco, seu chefe, reunia um 
verdadeiro exército de jagunços com o qual pretendia tomar desforço, e reentrar triunfante na cidade donde fora expedido com os seus amigos, e cruelmente maltratado. Era um verdadeiro estado de Guerra. (SAMPAIO) ${ }^{18}$

Descrevendo o primeiro encontro com Neco, Sampaio ressalta a hospitalidade: "Fomos, contudo, recebidos mui polidamente. O Neco não se fez esperar, e de boné na mão nos deu as boas vindas mui afavelmente”. Em Grande Sertão: Veredas, Selorico Mendes descreve um comportamento análogo: "- 'Sentei em mesa com o Neco, bebi vinho, almocei... Debaixo da chefia dele, paravam uns oitocentos brabos, só obedeciam e rendiam respeito"” (GS:V, p. 101-2). E o narrador afirma, com relação à situação na Januária: "Naquela dita ocasião, todas as pessoas importantes tinham fugido da Januária, desamparadas de poder-de-lei, foram esperar melhor sorte em Pedras-deMaria-da-Cruz.” (GS:V, p. 102). O que também é referido por Teodoro Sampaio:

Chegamos a Januária cerca de quatro horas da tarde e desembarcamos logo. Reinava na cidade um lúgubre silêncio. Era grande o terror entre os raros moradores que tinham permanecido e que, assustados, nos olhavam com desconfiança e se ocultavam logo. As ruas estavam desertas, as casas fechadas, o comércio recolhido, as autoridades fugitivas. Reinava o desânimo e o abandono era completo. (SAMPAIO, idem)

O narrador também refere outro evento histórico real, as investidas dos jagunços Andalécio e Antônio Dó contra a cidade de São Francisco, no ano de 1896:

\begin{abstract}
Mas, mire e veja o senhor: nas éras de 96, quando os serranos cismaram em avançar, tomaram conta de São Francisco, sem prazo nem pena. Mas, nestes derradeiros anos, quando Andalécio e Antônio Dó forcejaram por entrar lá, quase com homens mil e meio-mil, a cavalo, o povo de São Francisco soube, se reuniram, e deram fogo de defesa: diz-que durou combate por tempo de três horas, tinham armado tranquias, na boca das ruas - com tapigos, montes de areia e pedra, e árvores cortadas, de través - brigaram como boa população! (GS:V, p. 151).
\end{abstract}

Continuando, o narrador complementa: "Essas coisas já não aconteceram mais no meu tempo, pois por aí eu já estava retirado para ser criador, e lavrador de algodão e cana" (GS:V, p. 152). Com isso, percebemos que, em 1896, a batalha do Paredão já havia acabado e Riobaldo já tinha se retirado da vida jagunça.

No romance, também há o tempo de permanência do “doutor" na casa do narrador; corresponde ao tempo do diálogo de Riobaldo com ele:

\footnotetext{
${ }^{18}$ Apud. Petrônio Braz. In: Gazeta: Norte de Minas, 07-06-2009. Retirado do site em abril de 2011: http://www.gazetanortemineira.com.br/novogazeta/index.php?option=com_content\&view=article\&id=41 1:os-jaguncos-de-neco\&catid=24:petronio-braz\&Itemid $=23$.
} 
Eh, que se vai? Jàjá? É que não. Hoje, não. Amanhã, não. Não consinto. O senhor me desculpe, mas em empenho de minha amizade aceite: o senhor fica. Depois, quinta de-manhã-cedo, o senhor querendo ir, então vai, mesmo me deixa sentindo sua falta. Mas, hoje ou amanhã, não. Visita, aqui em casa, comigo, é por três dias! (GS: $V$, p. 21)

Esse tempo de três dias não determina necessariamente o tempo da narração, como o interpreta Francis Utéza no seu livro Metafisica do Grande Sertão (1994, p. 193), avançando uma interpretação metafísica em que os três dias são uma ilustração da Santíssima Trindade:

\begin{abstract}
Já se chamou a atenção para o fato de que o viajante chega à casa do 'barranqueiro' no terceiro dia da semana, segundo o calendário da língua portuguesa. Acrescente-se que o intervalo em que a pseudoconversação se estende, ainda que definido por três dias, se compõe efetivamente de dois terça e quarta-feira —-, estando o hóspede autorizado a seguir viagem na quinta-feira de manhã. E, como o narrador não menciona nunca no correr do discurso a eventual sucessão dos dias e das noites às margens do São Francisco, não existe a menor interrupção para descanso noturno nem preocupação com o decorrer das horas; assim, esse três não-dias, ilustrando a seu modo o mistério da Trindade, supõem a fusão da totalidade cronológica do quadro narrativo na unidade indiferenciada.
\end{abstract}

Acrescente-se a esse número três, diversas vezes enunciado durante o romance, a quantidade de vezes que o narrador conta a sua história:

\begin{abstract}
Os supostos três dias que o narratário passaria junto ao dono da Fazenda do Eterno Presente integram-se, pois, na cadeia aberta pela primeira narração que o ex-Urutu-Branco fazia a Zé Bebelo, durante outros três dias, em PortoPassarinho. Quando apenas terminava a aventura, no ponto exato em que se esfumava o tempo "histórico", Riobaldo iniciava outro tempo, o da narração. E fazia-o reprovando o projeto de Zé Bebelo de referir essas façanhas aos jornalistas - reprovação que vinha a significar que o relato da sua vida não se destinava ao grande público. Uma segunda versão, mais completa, seria reservada a Quelemém, indicado como pessoa idônea pelo próprio Zé Bebelo. Porém, nem as palavras de consolo nem o acolhimento caritativo deste sábio do sertão terão bastado para acalmar as terríveis dúvidas do jagunço arrependido, visto que ele sente a necessidade de consultar um terceiro "especialista", um "doutor" desconhecido atraído pelo estrondo de detonações. Então, em contraponto com os discursos lenificantes de Quelemém, o estrangeiro que se beneficia a priori dos prestígios do intelectual diplomado é convidado a se sentar na frente de nosso incansável narrador. (UTÉZA, 1994, p. 194-5)
\end{abstract}

Nesses exemplos, o tempo aparece como duração dentro da narrativa. Há outras duas marcações temporais interessantes. A primeira é a do tempo transcorrido dos acasos, idas e vindas de oito anos, pela viagem da carta que Nhorinhá, "puta e bela" personificação do amor carnal, envia para Riobaldo: 
Essa Nhorinhá tinha lenço curto na cabeça, feito crista de anú-branco. Escreveu, mandou a carta. Mas a carta gastou uns oito anos para me chegar; quando eu recebi, eu já estava casado. [...] Gosto de minha mulher, sempre gostei, e hoje mais. Quando conheci de olhos e mãos essa Nhorinhá, gostei dela só o trivial do momento. Quando ela escreveu a carta, ela estava gostando de mim, de certo; [...] Quando recebi a carta, vi que estava gostando dela, de grande amor em lavaredas; mas gostando de todo tempo, até daquele tempo pequeno em que com ela estive, na Aroeirinha, e conheci, concernente amor. Nhorinhá, gosto bom ficado em meus olhos e minha boca. De lá pra lá, os oitos anos se baldavam. Nem estavam. Senhor subentende o que isso é? A verdade que, em minha memória, mesmo, ela tinha aumentado de ser mais linda (GS: $V$, p. 89-90).

Os oito anos caracterizam o fim das andanças de Riobaldo pelo sertão, pois, como no exemplo dos jagunços das eras de 1896, ele já é proprietário de terra e casado. A carta traz o sentimento, o amor, que, se antes era "trivial", como recordação passa a ser "grande amor em lavaredas". Na sua reconstrução, o passado passa a ser outro. Ao ser recordado. Ainda como marcação temporal, que situa a ação do romance no século XIX, temos a certidão de nascimento de Diadorim:

Este papel, que eu trouxe - batistério. Da matriz de Itacambira, onde tem tantos mortos enterrados. Lá ela foi levada à pia. Lá registrada, assim. Em um 11 de setembro da éra de 1800 e tantos... O senhor lê. De Maria Deodorina da Fé Bettancourt Marins - que nasceu para o dever de guerrear e nunca ter medo, e mais para muito amar, sem gozo de amor... (GS:V, p. 550).

Não só como relato de fatos históricos ou marcação da duração aparece o tempo em Grande Sertão: Veredas, mas também relacionado a sentimentos, como é possível observar em diversos trechos. Para começar, o reencontro entre Riobaldo e Diadorim, que acontece após sua fuga do bando comandado por Zé Bebelo. O reencontro se dá no rancho do Malinácio perto do Rio das Velhas. Após o reconhecimento mútuo, Riobaldo parte com essa pequena comitiva do bando de Joca Ramiro, sob o comando de Titão Passos. Nesse local reinou a paz do lugar ameno onde aconteceram os melhores dias de Riobaldo e Diadorim:

Os dias que passamos ali foram diferentes do resto de minha vida. Em horas, andávamos pelos matos, vendo o fim do sol nas palmas dos tantos coqueiros macaúbas, e caçando, cortando palmito e tirando mel da abelha-de-poucasflores, que arma sua cera cor-de-rosa. (GS:V, p. 134).

Para conseguir permanecer aí, no lugar que tanto lhe agrada, Riobaldo usa de sua inteligência e malícia na argumentação: 
Assim mesmo, naquele estado exaltado em que andei, concebi fundamento para um conselho: na jornada por diante, a gente tinha de deixar duma bando do rio, ir passar a Serra-da-Onça e entestar com a travessia do Jequitaí, por onde podia ter tropa de soldados; mais ajuizado não seria se enviar só um, até lá, espiar o que se desse e colher outras informações? ( $G S: V$, p. 133)

Riobaldo é louvado e aumenta seu prestígio nessa parte do bando comandado por Titão Passos. Mas o narrador confessa os reais motivos que o fizeram dar o conselho:

Ao senhor confesso, desmedi satisfação, no ouvir aquilo - que a assoprada na vaidade é alegria que dá chama mais depressa e mais a ar. Mas logo me reduzi, atinando que minha opinião era só pelo desejo encoberto de que a gente pudesse ficar mais tempo ali, naquele lugar que me concedia tantos regalos. (GS:V, p. 135)

Apesar do visível remorso, Riobaldo não se arrepende, porque teve os melhores momentos que pode lembrar ao lado de Diadorim:

\begin{abstract}
Nunca mais, até o derradeiro final, nunca mais eu vi o Reinaldo tão sereno, tão alegre. E foi ele mesmo, no cabo de três dias, quem me perguntou: "Riobaldo, nós somos amigos, de destino fiel, amigos?" - "Reinaldo, pois eu morro e vivo sendo amigo seu!" - eu respondi. Os afetos. Doçura do olhar dele me transformou para os olhos de velhice da minha mãe. Então, eu vi as cores do mundo. Como no tempo em que tudo era falante, ai, sei. De manhã, o rio alto branco, de neblim; e o ouricurí retorce as palmas. Só um bom tocado de viola é que podia remir a vivez de tudo aquilo ( $G S: V$, p. 134-5).
\end{abstract}

É nesse lugar que Riobaldo descobre que ama Reinaldo, guerreiro jagunço, e isso o atormenta. É aí também que Reinaldo lhe revela o que seria o seu nome verdadeiro: "Pois então: o meu nome, verdadeiro, é Diadorim... Guarda este meu segredo. Sempre, quando sozinhos a gente estiver, é de Diadorim que você deve de me chamar, digo e peço, Riobaldo" (GS:V, p. 141).

Ainda relacionado ao sentimento amoroso, mas agora alegoricamente marcado pelo verde das folhas do buriti, temos o tempo do primeiro encontro entre Riobaldo e Otacília, na fazenda Santa Catarina:

Mas eu cacei melhor coragem, e pedi meu destino a Otacília. E ela, por alegria minha, disse que havia de gostar era só de mim, e que o tempo que carecesse me esperava, até que, para o tato de nosso casamento, eu pudesse vir com jús. Saí de lá aos grandes cantos, tempo-do-verde no coração ( $G S: V$, p. 179-180) (grifos meus) 
A respeito dessa presença do buriti, pode-se afirmar que, de todos os outros elementos que são animizados (vento, sertão, rio), ele é o único que está associado apenas a coisas puras, belas e a momentos de tranquilidade e paz. Nas palavras de Proença (s/d, p. 54), "o buriti é sempre uma nota de suavidade no livro intensamente dramático de Guimarães Rosa". Ele representa o aspecto lírico do romance ao produzir imagens "da casa e da mulher, da mãe cedo perdida, da noiva muito sonhada" (idem, p. 54) e, podemos acrescentar, dos olhos verdes de Diadorim, como confirma Cavalcanti Proença:

[...] o poeta Siruiz canta o "buriti — água azulada". E a canção de Siruiz é o encontro de Riobaldo com a poesia, a inesquecível lembrança, para sempre associada à neblina em que lhe apareceram os primeiros jagunços. A neblina será, para o homem, o passado diluindo lembranças, como é para o rio, o embrião do rio - o jagunço ainda em estado de névoa, antes da condensação que formaria as águas correntes da vida do cangaço. Buriti nasce nas cabeceiras, onde a água é pura. "Os brejos vão virando rios. Buritizal vem com eles, buriti se segue, segue." Daí, talvez, a associação facilmente identificável ao longo do livro, entre buriti e tranquilidade, buriti e noiva, buriti e mãe, buriti e poesia (PROENÇA, s/d, p. 54-55)

O buriti está presente nos momentos idílicos entre Riobaldo e Diadorim, como a suavizar a estranheza do sentimento amoroso entre homens machos:

Entretanto, os buritis emprestam sua doçura mesmo àquele sentimento condenado. Foi depois da travessia dum "rio vadoso, rio de beira baixinha, só buriti ali, os buritis calados" que Diadorim se virou para ele, "com um ar quase de meninozinho em suas miúdas feições" e disse: "Riobaldo, eu estou feliz". Há um momento em que Diadorim está quase a confessar o seu amor e o seu segredo: - "Por querer bem é que eu falo, Riobaldo..." - E aquelas palavras eram "feito sussurro nessas veredas, mão mansa, de tardinha, descabelando os buritizais." (idem, p. 57)

O buriti é referência temporal à brevidade da felicidade, como se segue:

No desconforto do acampamento, “alegria minha era Diadorim. (...) Fevereiro é o mês mindinho; mas é quando todos os cocos do buritizal maduram e no céu, quando estia, a gente acha reunidas as todas estrelas do ano todo. Muitas vezes eu ria." (idem)

Mas também o tempo se alonga, principalmente quando indica momentos difíceis, de grande perigo, como a batalha contra os judas na Fazenda dos Tucanos:

Mas conto menos do que foi: a meio, por em dobro não contar. Assim seja que o senhor uma idéia se faça. Altas misérias nossas. Mesmo eu - que, o 
senhor já viu, reviro retentiva com espelho cem-dobro de lumes, e tudo, graúdo e miúdo, guardo - mesmo eu não acerto no descrever o que se passou assim, passamos, cercados guerreantes dentro da Casa dos Tucanos, pelas balas dos capangas do Hermógenes, por causa. Vá de retro! - nanje os dias e as noites não recordo. Digo os seis, e acho que minto; se der por os cinco ou quatro, não minto mais? Só foi um tempo. Só que alargou demora de anos - às vezes achei; ou às vezes também, por diverso sentir, acho que se perpassou, no zuo de um minuto mito: briga de beija-flôr. ( $G S: V$, p. 314) (grifos meus)

Perde-se o tempo do calendário, pois a duração está subordinada ao sentimento de medo. $\mathrm{O}$ mesmo acontece quando Riobaldo relembra momentos que o atormentam, porque lhe denunciam a culpa pelos seus atos:

\begin{abstract}
Mas o mal de mim, doendo e vindo, é que eu tive de compensar, numa mão noutra, amor com amor. Se pode? Vem horas, digo: se um aquele amor veio de Deus, como veio, então - o outro?... Todo tormento. Comigo, as coisas não têm hoje e ant'ôntem amanhã: é sempre. Tormentos. Sei que tenho culpas em aberto. Mas quando foi que minha culpa começou? O senhor por ora mal me entende, se é que no fim me entenderá. Mas a vida não é entendível (GS: $V$, p. 127).
\end{abstract}

A culpa não é só dos atos passados, pois esses são apenas sua origem, já que ela se prolonga no presente, quando lembra e conta, e lança-se ao futuro como expectativa de que terá de pagar pelo que fez. O tempo também se alonga após a morte de Medeiro Vaz, quando Riobaldo diz: "Nunca, em todos meus tempos, eu vi inverno tamanho demorado. Era para espera" ( $G S: V$, p. 347-8). Ou quando Riobaldo está preste a fazer o pacto: "Com isso, o tempo mais parava" (GS:V, p. 376). No momento do pacto, o tempo é descrito como abismo: "Aquilo foi um buracão de tempo" (GS:V, p. 387). É nesse tempo do momento do pacto, quando Riobaldo obtém o poder do imaginário da força do sertão, que passa a ser sujeito da ação, o que é alegoricamente sugerido na passagem a seguir: "Decidi o tempo - espiando para cima, para esse céu: o Setestrêlo, nem as TrêsMarias, - já tinham afundado; mas o Cruzeiro ainda rebrilhava a dois palmos, até que descendo" (p. 384-5). O verbo decidir remete a duas significações. A primeira é denotativa, significando que o narrador estabelece o tempo por meio do movimento dos astros, como se fazia antigamente com o relógio de sol. A segunda é conotativa, já que o tempo, significando um ser, passa a ser subordinado ao poder do pactário Riobaldo.

Como afirmou Cavalcanti Proença, no trecho citado acima os elementos como rio, buriti, sertão e vento são animizados e, portanto, alguns deles também são temporalizados. O rio Urucúia, por exemplo, representa o tempo da tranquilidade, tempo idílico na pausa da guerra: "Momentos de calma, para Riobaldo, são passados à 
margem do Urucúia, 'paz das águas', embora o rio, em outros trechos, 'tão às brabas vá'. Mas, na ribeira escampada, à beira de suas águas, as borboletas são maiores, as aves cantam doce." E, "nos lugares tranquilos, nas horas de repouso, aparecem as aves ribeirinhas, e o manuelzinho-da-crôa se confunde com Diadorim." (PROENÇA, s/d, p. $33)$.

Outro personagem importante do plano mítico é o vento. Ele anuncia o futuro:

\begin{abstract}
Mensageiro de grandes notícias, precursor de acontecimentos decisivos talvez reminiscências bíblicas - o vento é personagem importante de Grande Sertão: Veredas. Animizado, é ele que leva as nuvens rabo-de-galo para fazerem ninho nos campos gerais, "nas beiras matas escuras e águas todas do Urucúia.” (PROENÇA, s/d, p. 48)
\end{abstract}

Os sentimentos e acontecimentos da vida de Riobaldo vêm acompanhados pela presença do vento, como o danado amor por Diadorim: "A paixão por Diadorim se revela numa tarde de muito vento" (PROENÇA, s/d, p. 48). Para o propósito deste estudo, é importante o caráter temporal do vento, que é significativo, por exemplo, no vento que Riobaldo recebe antes de chegar à Fazenda Santa Catarina. Segundo o narrador, é ar que lhe "falou em gritos de liberdade". Liberdade ambígua, pois se define, segundo Proença (s/d, p. 49), como "repouso e prisão no casamento". O vento "anuncia a vinda de Zé Bebelo que chega vencido, para ser preso e julgado: 'O vento vinha bom, da parte deles chegarem, de formas que o galope pronto se ouviu." (PROENÇA, s/d, p. 50). Ele também avisa da morte de Medeiro Vaz e de Joca Ramiro: "quando o vento dava para trás, trazia as tristes fumaças" (idem, p. 50). Outra morte também é anunciada pelo vento, sendo que essa é bem mais importante para Riobaldo: "O primeiro aviso de que Diadorim vai morrer na luta contra os judas é um golpe de vento.” (idem, p. 50). O vento traz o diabo no meio do redemunho, sina de Riobaldo quando, na encruzilhada, chama por ele e espera sua aparição na "lufa de um vendaval grande, com ele em trono" (GS:V, p. 385). E como diz Proença (s/d, p. 51):

[...] chama Satanaz e nada vê, nada ouve, apenas recebe "de volta um adejo". Aliás, desde que ouvira falar no pacto, a primeira vez, sabia que se o demo atendesse ao chamado, "há-de que vem um pé de vento sem razão."

Romance telúrico, em Grande Sertão: Veredas o narrador observa os elementos naturais, tenta desvendar seus sinais e adivinhar, por meio deles, o que acontecerá. Contudo, o processo não é fácil e as referências só são possíveis depois que o fato já 
aconteceu e se liga, como reconstrução do passado, à memória do narrador. Isso aparece, por exemplo, na véspera do combate final, no seguinte trecho:

Era uma noite de toda fundura. Estava dando um vento, esquisito para aquele tempo, por ser um vento em-hora do lado suão, em-hora do norte, conforme se riscando um fósforo, ou jogando punhado de areia fina para cima, se conhecia. (GS:V, p. 525-6)

Segundo Proença (s/d, p. 52), Riobaldo não entende o aviso que o vento dá, muito provavelmente por ter ficado cego pelo poder que conseguiu, o que também resulta na morte de Diadorim.

O tempo também é um ser, deus como o Chronos dos gregos, que destrói:

E tinha os restos de uma casa, que o tempo viera destruindo. (GS:V, p. 39)

Por mesmo, do Tamanduá-tão era a casa-de-fazenda - de muitos antigos tempos, quando tinha senzalas e um engenho-de-pau-em-pé. Mas já estava esquecida, arruinada em esteios, e com restos de parede fechando matagalzinho em cima de montes de terra e pedras, em fim de taperada. (GS:V, p. 498).

O tempo é claramente marcado pelo sentimento interior durante a narração. Assim, Riobaldo afirma que aquilo que era alegria, no passado, agora, no presente, é tristeza, o que caracteriza novamente seu arrependimento:

Para trás deixamos várzeas, cafundão, deixamos fechadas matas. $\mathrm{O}$ joãocongo piava cânticos, triste lá e ali em mim. Isto é, minto: hoje é triste, naquele tempo eram as alegrias $(G S: V$, p. 483$)$.

O tempo decorrido entre o passado e o presente talvez tenha sua manifestação mais evidente na fala de Diadorim:

— "Riobaldo, hoje-em-dia eu nem sei o que sei, e, o que soubesse, deixei de saber o que sabia..."

Demorei que ele mesmo por si pudesse pôr explicação. E foi ele disse: "Por vingar a morte de Joca Ramiro, vou, e vou e faço, consoante devo. Só, e Deus que me passe por esta, que indo vou não com meu coração que bate agora presente, mas com o coração de tempo passado... E digo..." (GS:V, p. 486).

Esse lamento do guerreiro cansado da guerra, mas que deve cumprir seu dever, vem após Diadorim questionar se Riobaldo, nesse momento chefe do bando, queria 
"aquela guerra completamente". Desconfiança de Diadorim, que o narrador afirma ter sido percebida pelo Riobaldo passado: "Tal achei áspero - que ele me condenava o vir dando tantas voltas, em vez de reto para topar o inimigo." (GS:V, p. 486). Na fala de Diadorim, surgem os dois tempos ligados ao sentimento, coração, pois a morte dos dois judas era questão de honra. Assim, tentando explicar a confusão que vai em seu ser ("hoje-em-dia eu nem sei o que sei, e, o que soubesse, deixei de saber o que sabia"), Diadorim tenta mostrar a Riobaldo que no presente seu coração bate por outra razão, ficando subentendido que pelo próprio Riobaldo.

O tempo também surge como o Destino, sempre a partir das análises que Riobaldo faz do que aconteceu. Por exemplo, quando conta o reencontro com Diadorim na casa do Malinácio, em vez de se alegrar, no presente da narração, pelo que aconteceu, lamenta-se, pois sabe o que acontecerá:

\begin{abstract}
Se eu não tivesse passado por um lugar, uma mulher, a combinação daquela mulher acender a fogueira, eu nunca mais, nesta vida, tinha topado com o Menino? - era o que eu pensava. Veja o senhor: eu puxava essa idéia; e com ela em vez de me alegre ficar, por ter tido tanta sorte, eu sofria o meu. Sorte? O que Deus sabe, Deus sabe. Eu vi a neblina encher o vulto do rio, e se estralar da outra banda a barra da madrugada ( $G S: V$, p. 129).
\end{abstract}

A mulher em questão é a filha do Malinácio, com a qual Riobaldo havia combinado que ela acendesse uma fogueira, para indicar que seu marido não estava em casa, a fim de terem mais um encontro amoroso. Observando do presente a sequência dos fatos, o narrador se questiona sobre a sorte e direciona a dúvida para a Providência, Destino, Deus.

E foi o acaso que o levou àquela mulher. Não uma fêmea qualquer, mas a mulher que o Destino escolhera. Por causa dela não viaja, fica para dormir esperando a mensagem da fogueira. E quem chega é o Menino com os jagunços de Joca Ramiro. Estava escrito. Como estava escrito nas páginas da infância aquele primeiro encontro no porto do de Janeiro onde o levara promessa da mãe ao Bom Jesus da Lapa.

Nunca mais o Destino há de abrir mão dele. Usa-o como instrumento para salvar Zé Bebelo da morte em combate, para absolvê-lo no julgamento da Sempre-Verde. É que já havia decidido: um dia, Riobaldo tomaria a Zé Bebelo o posto de chefe. (PROENÇA, s/d, p. 60-1)

Como o Destino não o abandona mais, surge novamente quando o narrador analisa a existência da alma e questiona se ela é vendível: 
Pois, não existe! E, se não existe, como é que se pode contratar pacto com ele? E a idéia me retorna. Dum mau imaginado, o senhor me dê o lícito: que, ou então - será que pode também ser que tudo é mais passado revolvido remoto, no profundo, mais crônico: que, quando um tem noção de resolver a vender a alma sua, que é porque ela já estava dada vendida, sem se saber; e a pessoa sujeita está só é certificando o regular dalgum velho trato — que já se vendeu aos poucos, faz tempo? (GS:V, p. 34).

O tempo surge nesse trecho como karma. Por isso, o narrador o teme e respeita: "Os dias de chover cheio foram se emendando. Tudo igual - às vezes é uma semgracez. Mas não se deve de tentar o tempo." (GS:V, p. 269).

Romance telúrico, Riobaldo interpreta os sinais do Destino para adivinhar o futuro, como diz Proença (s/d, p. 62):

Homem do sertão, Riobaldo interpreta os sinais do Destino. Na primeira luta contra Zé Bebelo, comandado, ainda, por Hermógenes, logo sabe que perderão a batalha: "Por lá a coruja grande avoa, que sabe bem aonde vai, sabe sem barulho. A quando vulto dela assombrava, em frente da gente no ar, eu fechava os olhos três vezes". A coruja é o nome do retiro taperado de onde saiu para fazer o pacto; e, relembrando os sofrimentos daqueles dias de doença e desânimo para a tropa, evoca, como única desculpa para o seu pecado "a lugugem do canto da mãe-da-lua em cada anoitecer".

Contudo, nas vésperas da batalha do Paredão, o futuro está oculto:

Que modo que senseei, do vazio do tempo em redor - e que eu entredisse: — “O Sertão vem?" Vinha. Trinquei os dentes. Mordi mão de sina. Porque era dia de antevéspera: mire e veja. Mas isso, tão em-pé, tão perto, ainda nuveava, nos ocultos do futuro. (GS:V, p. 512).

Sobre o futuro e o Destino, o que dizer daqueles que podem ver por trás dos panos, como a Ana Duzuza, chamada por Medeiro Vaz nas vésperas de se tentar a primeira travessia do Liso do Sussuarão?

Mãe dela chegou, uma velha arregalada, por nome de Ana Duzuza: falada de ser filha de ciganos, e dona adivinhadora da boa ou má sorte da gente; naquele sertão essa dispôs de muita virtude. (GS:V, p. 29)

O poder de adivinhação da velha é, contudo, negado por Diadorim, que vê nela apenas um estorvo, pois abalou a determinação de Medeiro Vaz:

Diadorim, de vez mais sério, temperou: - "Essa velha Ana Duzuza é que inferna e não se serve... Das perguntas que Medeiro Vaz fez, ela tirou por tino a tenção dele, e não devia de ter falado as pausas... Essa carece de morrer, para não ser leleira..." (GS:V, p. 31-2) 
Falar "as pausas" demonstra o poder do silêncio do que não pode ser dito e é inomeável. A fala de Diadorim indetermina a possibilidade de se ler o futuro. Caso Ana Duzuza estivesse certa, o bando não conseguiria atravessar o liso, o que realmente aconteceu. Mas teria sido pela falta de determinação do chefe, abalada pela fala da velha adivinhadora, que o fez fracassar? A pergunta permanece, pois sua função é não haver resposta. Maneira magistral de lidar com o futuro e com o Destino.

A chuva surge em momentos de tristeza, como na morte da mãe de Riobaldo:

Adiante? Conto. O seguinte é simples. Minha mãe morreu — apenas a Bigrí, era como ela se chamava. Morreu, num dezembro chovedor, aí foi grande a minha tristeza (GS:V, p. 99-100).

Ou a de Medeiro Vaz:

Aí, chamaram: - "Acode, que o chefe está no fatal!" Medeiro Vaz, arquejando, cumprindo tudo. E o queixo dele não parava de mexer; grandes momentos. Demorava. E deu a panca, troz-troz forte, como de propósito: uma chuva de arrobas de peso. Era quase sonoite (GS:V, p. 70).

O tempo aparece, principalmente, como distância entre o presente e o passado, principalmente quando usado com o pronome demonstrativo "aquele":

O Chapadão é uma estada, estando. Somente eu sabia respirar. Sumo bebi de mim, e do que eu não me tonteava. Só estive em meus dias. E ainda hoje, o suceder deste meu coração copia é o eco daquele tempo; e qualquer fio de meu cabelo branco que o senhor arranque, declara o real daquilo, daquilo sem traslado... (GS:V, p. 424) (grifo meu)

De seguir assim, sem a dura decisão, feito cachorro magro que espera viajantes em ponto de rancho, o senhor quem sabe vá achar que eu seja homem sem caráter. Eu mesmo pensei. Conheci que estava chocho, dado no mundo, vazio de meu dever honesto. Tudo, naquele tempo, e de cada banda que eu fosse, eram pessoas matando e morrendo, vivendo numa fúria firme, numa certeza, e eu não pertencia a razão nenhuma, não guardava fé e nem fazia parte. ( $G S: V$, p. 128) (grifo meu)

A rapidez do tempo é expressa de diversas maneiras. Às vezes utilizando diminutivo:

O tempozinho todo, naquele soflagrante. E estúrdio: eu principalmente não queria Diadorim perto de mim, para as horas. (GS:V, p. 184) (grifos meus)

Já em outras, basta uma sílaba para que a significação / rapidez/ ocorra: 
Digo ao senhor: se o demônio existisse, e o senhor visse, ah, o senhor não devia de, não convém espiar para esse, nem $m i$ de minuto! — não pode, não deve-de! (GS:V, p. 211) (grifo meu)

Contudo, algumas vezes é necessária a união de duas palavras e a supressão de uma vogal para exprimi-lo:

O fechabrir de olhos, e eu também tinha agarrado meu revólver. (GS:V, p. 145) (grifo meu)

Em outros trechos, o tempo relacionado ao grau diminutivo de um adjetivo expressa o momento acolhedor de amizade:

Entramos no meio deles, misturados, para acocorar e prosear caçamos um pé de fôgo. Novidade nenhuma, o senhor sabe - em roda de fogueira, toda conversa é miudinhos tempos. (GS:V, p. 144) (grifo meu)

Em alguns trechos esse tempo curto, de instantes, além de possuir um ser, tornase extremamente poderoso ao significar os sentimentos contraditórios, o amor e o ódio:

Mas, Diadorim? De olhos os olhos agarrados: nós dois. Asneira, eu naquela hora supria suscitar alto meu maior bem-querer por Diadorim; mesmo, mesmo, assim mesmo, eu arcava em crú com o desafio, desde que ele brabasse, desde que ele puxasse. Tempo instante, que empurrou morros para passar... Afinal, aí, Diadorim abaixou as vistas. (GS:V, p. 75) (grifo meu)

Metaforicamente, o tempo rápido também surge:

Isso tudo se deu curto, que nem o mijar dum sapo; e dum modo tal inocente, de quem visse risse. (GS:V, p. 361) (grifo meu)

Quando é preciso pensar rápido, como na batalha contra o Ricardão, o narrador diz:

Mas eu sabia que era o minuto e não era a hora. (GS:V, p. 501) (grifos meus)

O tempo também ganha adjetivos ou predicados que o determinam de acordo com a situação. Assim, os momentos de libertinagem dos jagunços com meretrizes são "horas safadas": 
— "Saindo por aí," - dizia um - "qualquer uma que seja, não me escapole!" Ao que contavam casos de mocinhas ensinadas por eles, aproveitavelmente, de seguida, em horas safadas. (GS:V, p. 157) (grifo meu)

A progressão do momento da morte é "pobres horas":

Mas uma jararaca picou o Gregoriano: era aquela, a rastejo no capim e nas folhas caídas, nem chegava a quatro palmos - e com poder de acabar - e o Gregoriano morreu, em pobres horas. (GS:V, p. 370) (grifo meu)

Momentos de espera são caracterizados com o passar do tempo, que sofre sua própria ação e fica velho:

Mas que em desregra a gente se comportava, então, de parar ali envelhecendo os dias, na Coruja, como fosse menos-e-mais para aproveitar a carne fresca e de-sol que na campeação se conseguia, as boiadas daqueles sertões. (GS:V, p. 371) (grifo meu)

Já a certeza, assim como a alegoria da paz das folhas do buriti, é verde, como no trecho abaixo em que Riobaldo não cisma "incerteza" de que irá derrotar o Hermógenes:

E ele, ele mesmo, não era que era o realce meu - ? - eu carecendo de derrubar a dobradura dele, para remedir minha grandeza façanha! E perigo não vi, como não estava cismando incerteza. Tempo de verde! Êpa, eu ia erguer mão e gritar um grito mandante - e o Hermógenes retombava. ( $G S: V$, p. 492-3) (grifo meu)

Contudo, o pecado, figurado no trecho a seguir pelo estupro, alude a uma duração indeterminada, "além", que sugere a Providência:

Mas, depois, num sítio perto da Serra Nova, foi uma outra, a moreninha miúda, e essa se sujeitou fria estendida, para mim ficou de pedras e terra. Ah, era que nem eu nos medonhos fosse - e, o senhor crê? - a mocinha me aguentava era num rezar, tempos além. Às almas fugi de lá, larguei com ela o dinheiro meu, eu mesmo roguei pragas. Contanto que nunca mais abusei de mulher. Pelas ocasiões que tive, e de lado deixei, ofereço que Deus me dê alguma minha recompensa. (GS:V, p. 157) (grifos meus)

Essas formas de representar o tempo demonstram duas coisas. A primeira é que a referência a ele é presente durante todo o romance, exprimindo sentimentos, 
acontecimentos importantes, elementos da natureza etc. A segunda é a absoluta capacidade inventiva do autor, que faz as palavras significar o que deseja. 


\section{CAPÍtulo 3: O TEMPo dAS ESTRUTURAS}

Mas conto. Conto para mim, conto para o senhor. Ao quando bem não me entender, me espere. (GS:V, p. 131)

Esse capítulo é dividido em três partes. Na primeira, "O espaço do diálogo", analisamos o local em que acontece a cena do diálogo entre os dois atores da enunciação, isso é, o narrador e o "doutor". O objetivo é demonstrar como o espaço é importante para a constituição de um tempo do filosofar, realizável na narrativa a partir da atmosfera de segurança e tranquilidade constituídas pela posição social de fazendeiro do narrador. Na segunda parte, "O ethos do narrador e a estrutura da cena do diálogo", apresenta-se a constituição da figura do narrador e a sua importância para a organização da narrativa e, portanto, para as temporalidades existentes nela. Junto a isso, define-se a temporalidade instaurada pela cena dramática da enunciação, que atualiza pela enunciação presente os fatos, lembranças, reminiscências, da vida o jagunço, atirador e chefe Riobaldo. Na última parte, desenvolve-se a importância do espaço do diálogo e do tempo da enunciação na arquitetura da escrita do romance, demonstrando-se como o narrar em vai e vem, cujos blocos se misturam, é, na verdade, um reflexo de um devir outro do eu, ou dos eus, do narrador Riobaldo. Isso temporaliza toda a narração, causando o que muitos consideram a dificuldade da primeira leitura do livro, visto ele não seguir o enredo dos romances tradicionais.

O objetivo com este último capítulo é expor como as formas se temporalizam e engendram um jogo com os tempos muito sutil, bem estilizado, sugerindo uma emulação artificiosa, por parte de Guimarães Rosa, da técnica romanesca dos séculos XVIII e XIX - cuja principal figura no Brasil foi Machado de Assis - que consistia em um jogo com os tempos da narrativa e para isso impunha a elaboração de um interlocutor, o chamado "leitor implícito".

\section{O espaço do diálogo}

Neste subcapítulo, estudaremos as características do espaço na constituição da cena inicial forjada como diálogo entre Riobaldo - velho barranqueiro e narrador dos 
fatos - e o "doutor", que o ouve. Grande Sertão: Veredas é uma obra que, predominantemente, trata do espaço, pois o narrador descreve as mínimas particularidades dos locais significativos da história. Essa afirmação faz mais necessária a abordagem sobre o espaço do diálogo, porque ele não é definido como os outros. Nossa hipótese é de que, apesar dos poucos elementos que o descrevem, o espaço do diálogo é uma reestilização do espaço grego do diálogo filosófico no sertão. Defendemos nossa posição com base nos estudos que já demonstraram a utilização por parte de Guimarães Rosa de referências da filosofia grega antiga e de outras tradições textuais clássicas e medievais. Assim, temos no texto algumas características do romance de cavalaria, retomado e estilizado por meio da tradição popular que transmitiu e reorganizou suas histórias e inventou personagens nos cordéis nordestinos, por exemplo. O primeiro estudo a abordar as apropriações do romance de cavalaria por Rosa foi o de Cavalcanti Proença, chamado Trilhas no Grande Sertão. Nele, o autor divide o romance de Rosa em dois planos, sendo um subjetivo e outro objetivo. Os dois planos se entrecruzam e são superpostos, criando a trama de efabulação do romance. Para fazer a exegese da efabulação, Cavalcanti Proença propõe outra divisão, agora em três partes: individual, coletiva e telúrica. A primeira liga-se aos questionamentos internos do narrador, portanto, ao plano subjetivo, cujo conteúdo é o "antagonismo entre os elementos da alma humana" (PROENÇA, s/d, p. 9). A segunda, coletiva, acrescenta informações à primeira do plano subjetivo, pois trata do estilo de Guimarães Rosa, isso é, a estilização que o autor faz da tradição cultural, cujo símile é o herói medieval, agora “aculturado nos sertões do Brasil Central” (PROENÇA, s/d, p. 9). Já a última, telúrica, personifica os elementos naturais como sertão, vento, rio, buritis etc. Nesse momento, para cumprir o intuito de justificar a presença de um diálogo filosófico de acordo com os preceitos gregos, estudaremos apenas a segunda parte, que se refere às características épicas da obra.

Assim, tratando do que propõe como a parte coletiva, Cavalcanti Proença classifica Grande Sertão: Veredas como uma epopeia, valendo-se de características como o protagonismo de Riobaldo, a intercalação de episódios na trama principal, a apropriação de material da cultura popular que, por sua vez, tem sua base no romance de cavalaria (PROENÇA, s/d, p. 13 a 14). A partir desse ponto, o autor demonstra as diversas características dos romances de cavalaria presentes em Grande Sertão: Veredas. São elas a virtude heroica que alcança seu auge quando Riobaldo se torna chefe jagunço; cangaceiro cortês, pois não comete barbaridades; voto de castidade; os 
chefes caracterizados com traços de honra guerreira e (des)lealdade medievais, sendo que o autor os compara com personagens como Carlos Magno (Medeiro Vaz), Rolando (Joca Ramiro), Dom Galvan (Hermógenes e Ricardão). Relaciona também as ações, como a travessia do Liso do Sussuarão, que resultou em fracasso quando comandada por Medeiro Vaz, às tentativas também fracassadas de Percival e Lancelote de dar cabo das maravilhas do reino de Logres. No caso, a ação só pode ser realizada por Galaaz, emulado por Riobaldo, que atravessa o Liso, sem se preocupar com as provisões. Consta também a mudança de apelido de Tatarana (jagunço) para Urutu-Branco (chefe). A lealdade a um código, como a pausa na guerra na fazenda abandonada, onde foram mortos os cavalos; a descrição minuciosa dos preparativos às vésperas das batalhas; o encontro com os catrumanos, que é comparado à Ilha Encantada de Clarimundo ou à aventura do homem da cadeira, de Percival e Lancelote; e, por fimm ${ }^{19}$, a presença de Diadorim, personagem ausente que fundamenta a estruturação do romance na cronologia de vai-e-vem da memória de Riobaldo e suas deixas, que sugerem suas características equívocas (PROENÇA, s/d, p. 15-29).

Além das referências que Cavalcanti Proença faz, também há uma passagem que faz referência explícita ao diálogo na correspondência entre João Guimarães Rosa e Edoardo Bizzarri, seu tradutor italiano. Numa carta de 25 de novembro de 1963, o diplomata escreve sobre as novelas de Corpo de Baile e, em determinado trecho, afirma:

E eu mesmo fiquei espantado de ver, a posteriori, como as novelas, umas mais, outras menos, desenvolvem temas que poderiam filiar-se, de algum modo, aos "Diálogos", remotamente, ou às "Enéadas", ou ter nos velhos textos hindus qualquer raizinha de partida. Daí, as epígrafes de Plotino e Ruysbroeck. (ROSA, 2003, p. 90)

O homem Guimarães Rosa é sagaz, disfarça bem, mas sua "sem imodéstia" (Idem) é contradita, bem propositadamente, quando afirma a presença das epígrafes de Plotino e Ruysbroeck, havendo, assim, menos de leitura a posteriori do que ele gostaria de afirmar. A indicação do texto das seis Enéadas de Plotino se acompanha da referência aos Diálogos de Platão. Ainda na mesma carta, Guimarães Rosa continua falando de seu processo de escrita:

Ora, Você já notou, decerto, que, como eu, os meus livros, em essência, são "anti-intelectuais" — defendem o altíssimo primado da intuição, da

\footnotetext{
${ }^{19} \mathrm{O}$ fim refere-se a nossa enumeração e citação. Proença cita mais algumas características e elementos semelhantes ao romance medieval. Ao nosso intuito bastam as classificadas.
} 
revelação, da inspiração sobre o bruxolear presunçoso da inteligência reflexiva, da razão, a megera cartesiana. Quero ficar com o Tao, com os Vedas e Upanixades, com os Evangelistas e São Paulo, com Platão, com Plotino, com Bergson, com Berdiaeff - com Cristo, principalmente. (ROSA, 2003, p. 90) (grifos meus)

Aceitando, portanto, a citação dos Diálogos de Platão na obra de Guimarães Rosa, estabeleceremos uma aproximação entre o Fedro e a constituição do espaço do diálogo da cena inaugural do romance, para levantar traços que comprovem o objetivo de elaborar uma atmosfera de calma e tranquilidade para que os assuntos pudessem ser apresentados durante os três dias de conversa.

No Fedro, conta-se que Sócrates, ao encontrar Fedro saindo da cidade, chama-o. Este lhe diz que vem da casa de Lísias, onde esteve durante várias horas, ouvindo um discurso sobre o amor do anfitrião. Sócrates, então, acompanha-o para fora dos muros da cidade a fim de ouvir o tal discurso. O propósito de Fedro ao sair da cidade é justamente guardar na memória ${ }^{20}$ o que leu e ouviu durante a madrugada ${ }^{21}$. Querendo aproveitar a oportunidade para praticá-la, Fedro dá a entender que reproduzirá o discurso de memória. Sócrates, porém, percebe que Fedro segura um pergaminho na mão esquerda e, deduzindo ser o discurso de Lísias, assim se dirige ao amigo:

Sócrates: - Antes, porém, meu amiguinho, mostra-me o que tens na mão esquerda, debaixo do teu manto! Suspeito que seja o próprio discurso. Caso eu tenha acertado, convence-te disto: tu és meu grande amigo, mas, estando o próprio Lísias desse modo presente não estou decidido a te permitir uma simples repetição (PLATÃO, s/d, p. 200).

Frustrado, assim, em fazer um exercício de memória, só resta a Fedro sugerir um lugar ameno para a leitura do discurso de Lísias. E aqui chegamos ao que nos interessa para este estudo: o lugar propício para se ouvir um discurso e refletir sobre ele. $\mathrm{O}$ cenário para a reprodução do discurso não é qualquer, mas um escolhido cuidadosamente, com o propósito de representar a tranquilidade necessária para o diálogo. Sócrates sugere que ambos abandonem a estrada e caminhem pelo Ilisso ${ }^{22}$, de onde avistam um plátano e para lá se dirigem. Assim é descrito, por Sócrates, o local do diálogo:

\footnotetext{
${ }^{20}$ Platão. Fedro, s/d, 199: "Sócrates: Além disso, ele [referindo-se ao próprio Lísias] se dirige para fora dos muros a fím de gravá-lo bem na memória."

${ }^{21}$ Platão. Fedro, s/d, p. 197: "Estive lá [na casa de Lísias] sentado durante muitas horas, desde a madrugada."

${ }^{22}$ Platão, Fedro, s/d, p. 200: "Sócrates: - Afastemo-nos aqui da estrada e caminhemos ao longo do Ilisso. Mais adiante poderemos sentar-nos à vontade e estaremos sossegados."
} 
Por Hera, que é um bonito lugar! Êste plátano estende muito os seus ramos e é bem alto, e também este agnocasto tem uma bela altura e lança magnífica sombra. Além disso, está todo em flor e espalha por aqui um cheiro delicioso. Sob a ramagem do plátano corre uma bonita fonte de água fresca, como a estou a sentir nos pés. A julgar pelas estátuas e oblações, parece ser um lugar consagrado a Aquelôo e às Ninfas. A brisa aqui é suave, o côro das cigarras ressoa lá no alto, tal como na primavera. O mais belo, porém, é a relva, bastante densa para oferecer à cabeça um confortável travesseiro com o seu brando declive. És um excelente guia, caro Fedro! (PLATÃO, s/d, p. 202)

O lugar é definido por algo além da tranquilidade. O agnocasto é uma árvore cujo fruto, durante muito tempo, foi usado como antiafrodisíaco. Esse grande arbusto também era conhecido como árvore-da-castidade e testículo-de-frade. Representa a anulação do amor carnal, afirmando a superioridade do amor ideal, que será defendida por Sócrates. Além disso, eles também estão protegidos por Aquelôo e pelas Ninfas, sendo esse um local sagrado. Eis o cenário (protegido) e a atmosfera (tranquila) para o diálogo filosófico.

Em Grande Sertão: Veredas, quando se inicia a fala do narrador Riobaldo, não há qualquer descrição do espaço em que estão os dois interlocutores. Ao que parece, a fala tem um início arbitrário, um ponto escolhido pelo autor, pois tudo indica que ela já havia começado antes da palavra enunciada “- Nonada”, que abre a narrativa para o leitor. Isso porque "-Nonada" pode ser lido como uma resposta dada por Riobaldo a alguma pergunta - implícita (como são todas elas) - do interlocutor. A primeira referência é uma pequena descrição que possibilita ao leitor saber onde estão os atores da cena dialógica: "Alvejei mira em árvore, no quintal, no baixo do córrego" (GS:V, p. 5). Depois, um pouco adiante na narração, Riobaldo diz: “O senhor tolere, isto é o sertão" (GS:V, p. 5). Aqui se define o espaço maior no qual está situada a cena menor de diálogo: sertão. Tenta-se, em seguida, uma definição do que ele é: "Uns querem que ele não seja: que situado sertão é por os campos-gerais a fora a dentro, eles dizem, fim de rumo, terras altas, demais do Urucúia" ( $G S: V$, p. 5). A definição não é particular do narrador, mas sim de âmbito geral, como se percebe pelo pronome e pelo verbo na terceira pessoa do plural: “eles dizem”. Essa caracterização do sertão não é, porém, compartilhada pelo narrador, como se vê: "Toleima. Para os de Corinto e do Curvelo, então, aqui não é dito sertão?" ( $G S: V$, p. 5). O sertão, a partir da pergunta, passa a ser definido pelo ponto de vista daquele que o define. Questionador, Riobaldo busca outras maneiras de apresentar o sertão ao seu interlocutor: “Ah, que tem maior! Lugar sertão se divulga: é onde os pastos carecem de fechos; onde um pode torar dez, vinte léguas, sem topar com casa de morador; e onde criminoso vive seu cristo-jesus, arredado do arrocho 
de autoridade" ( $G S: V$, p. 5). Situado aqui como um grande deserto, uma imensidão sem tamanho, sem autoridade, ele é amplificado ainda mais: "O sertão está em toda parte" (GS:V, p. 5). Em todas essas citações, o sertão é definido como espaço físico, mas apenas o geográfico não é suficiente para abrangê-lo, já que também é caracterizado pelas pessoas que nele vivem: "Sertão. O senhor sabe: sertão é onde manda quem é forte, com as astúcias" (GS:V, p. 15). Por fim, o narrador aponta outros caminhos para mostrar ao seu interlocutor o que é o sertão e, para isso, abandona o espaço físico e quase o humaniza: "Sertão é o sozinho" ( $G S: V$, p. 282). Sem espaço físico, o sertão passa a ser transcendental, metafísico: "Sertão: é dentro da gente" (GS:V, p. 282). Essa variedade de tentativas de definir o sertão é mostra de relações dialógicas: o narrador dialoga com o que o povo diz ("uns querem..."), posicionando-se em relação às definições populares (“Toleima...”), e formulando outras, partindo de sua experiência como morador e conhecedor do sertão. Por esse motivo, por conhecer, por ter sentido o sertão, é que o narrador pode chegar às suas próprias definições do lugar, que avançam para significações metafísicas de um não-lugar.

Sabemos que a cena do diálogo ocorre em um lugar dentro desse sertão definível e indefinível. Também nos é dito onde estão os atores desse diálogo: "Ele era rico e somítico, possuía três fazendas-de-gado. Aqui também dele foi, a maior de todas" (GS:V, p. 100). Riobaldo refere-se ao seu pai/padrinho Selorico Mendes. Dele, recebeu duas fazendas, sendo que só podemos saber que nenhuma delas é a São Gregório, que foi deixada para uma mulata: "E me deixou por herdeiro, em folha de testamento: das três fazendas, duas peguei. Só o São Gregório foi que ele testou para uma mulata, com que no fim de sua velhice se ajuntou" (GS:V, p. 104). Não se sabe, portanto, em qual das duas fazendas os atores da cena dramática estão. Assim, apesar de não haver muitos detalhes que caracterizem o espaço da conversa, são apresentados alguns indícios, que, se não definem particularmente o local, também não deixam de mencioná-lo e delimitálo. Por isso é importante que o lugar da cena dramática - que tem a funcionalidade de servir de ambiente para que o narrador conte suas aventuras, portanto, palco para o épos - seja uma fazenda rodeada pelo sertão, pois é nesse espaço (in)definido que ocorreram os acontecimentos.

Voltando à descrição do local da cena dramática, sabemos que o lugar da conversa é bem defendido por Riobaldo, que, apesar de velho barranqueiro, ainda treina atirando em árvores e se mostra valente e destemido: "Chegassem viessem aqui com guerra em mim, com más partes, com outras leis, ou com sobejos olhares, e eu ainda 
sorteio de acender esta zona, ai, se, se! É na boca do trabuco: é no te-retê-retém" ( $G S: V$, p. 20). Além disso, o narrador faz questão de mostrar que não está sozinho, que tem sua "gente" à sua volta: "E sozinhozinho não estou, há-de-o. Pra não isso, hei coloquei redor meu minha gente" (GS: $V$, p. 20). A defesa do lugar, como acontece também no Fedro, é requisito para que as personagens do diálogo não sejam interrompidas ou tenham preocupações exteriores ao assunto que será tratado. E tudo isso é apresentado bem no início do livro, pois é preciso criar a atmosfera de tranquilidade para que se comece a narração da história propriamente dita. A segurança é reforçada quando o narrador mostra onde estão os que protegem a fazenda e os atributos que cada um possui:

\begin{abstract}
Olhe o senhor: aqui, pegado, vereda abaixo, o Paspe - meeiro meu - é meu. Mais légua, se tanto, tem o Acauã, e tem o Compadre Ciril, ele e três filhos, sei que servem. Banda desta mão, o Alaripe: soubesse o senhor o que é que se preza, em rifleio e à faca, um cearense feito esse! Depois mais: o João Nonato, o Quipes, o Pacamã-de-Presas. E o Fafafa - este deu lances altos, todo lado comigo, no combate velho do Tamanduá-tão: limpamos o vento de quem não tinha ordem de respirar, e antes esses desrodeamos... $\mathrm{O}$ Fafafa tem uma eguada. Ele cria cavalos bons. Até um pouco mais longe, no pé-de-serra, de bando meu foram o Sesfrêdo, Jesualdo, o Nelson e João Concliz. Uns outros. (GS:V, p. 20)
\end{abstract}

Vários nomes são apresentados, alguns dos quais o leitor encontrará durante a leitura do livro, mas o narrador já adianta um: o Fafafa, que participou do último combate de Riobaldo como chefe no Tamanduá-tão, o que, aliás, também é mencionado ("de bando meu foram"). Contudo, propositadamente, o narrador afirma ao interlocutor que seus companheiros não estão lá para lutar e sim para viver em paz, o que restaura a tranquilidade ao ambiente do diálogo:

Estão aí, de armas areiadas. Inimigo vier, a gente cruza chamado, ajuntamos: é hora dum bom tiroteiamento em paz, exp'rimentem ver. Digo isto ao senhor, de fidúcia. Também, não vá pensar em dobro. Queremos é trabalhar, propor sossego. De mim, pessoa, vivo para minha mulher, que tudo modomelhor merece, e para a devoção. (GS:V, p. 20)

O narrador termina falando de religião, como para trazer a paz ao lugar em que conversam, e mantém, assim, o sossego entre ele e o interlocutor. Mas ao mesmo tempo já lhe deu o recado de que no sertão a paz só existe por meio do poder, que, no caso, é representativo da posição de fazendeiro que Riobaldo possui. A palavra "fidúcia" mostra bem a transposição do ambiente armado, preparado para a batalha, para a 
tranquilidade sobrevinda dele. Isso é um alerta para que o doutor, assim como o leitor, não pense em exagero ("Também, não vá pensar em dobro"), pois o narrador fala ousadamente, com atrevimento e, talvez, com vaidade, sobre o que possui ("Digo isto ao senhor, de fidúcia”). Essa caracterização, portanto, não é só do espaço, mas também do ambiente, visto que este é determinado pelas condições daquele. Como o lugar é propício ao diálogo, também a relação entre os atores é propícia, o que pode ser visto em ações simples, como tomar café e fumar: "Vai assim, vem outro café, se pita um bom cigarro" (GS:V, p. 282).

O gênero do diálogo está constituído em Grande Sertão: Veredas, pois há duas personagens que interagem, há um espaço para que ele ocorra e há uma atmosfera tranquila para sua execução. Para nós, essas características do diálogo filosófico são importantes para definir o que Paulo de Tarso Santos denominou, no seu livro $O$ diálogo no Grande Sertão: Veredas ${ }^{23}$, de "ser de convivência" (1978, p. 17), que, para ele, está resumido no seguinte trecho da obra de Rosa:

Sendo isto. Ao dôido, doideiras digo. Mas o senhor é homem sobrevindo, sensato, fiel como papel, o senhor me ouve, pensa e repensa, e rediz, então me ajuda. (GS:V, p. 90)

Segundo Paulo de Tarso, estão aí

[...] todos os elementos do diálogo [...]: a humildade de escutar, por crer na fala do outro como uma contribuição possível; a necessidade de reflexão (pensar e repensar) antes da resposta; o redizer já como síntese das culturas que se encontram e o desejo de ajudar, como o amor de pessoa a pessoa, base da convivência[...] (SANTOS, 1978, p. 17)

Aconteceria, em consequência do diálogo, uma purgação:

E sem exagero, pode-se falar de um certo estado de catarse psicológica ou liberação de Riobaldo, que vai ocorrendo ao longo do diálogo. É bom lembrar que como "ser da convivência", o homem se realiza no encontro inter-humano, a tal ponto que se pode falar que mais liberto ou adulto é o homem que logrou mais encontros, plenos, ao longo da vida. (Idem)

O diálogo cumpre o papel de propiciar a atmosfera e o momento para que Riobaldo consiga contar sua história, mas ele não consegue se livrar dos tormentos que o motivaram a iniciá-la. Em outras palavras, concordamos com a hipótese de Santos

\footnotetext{
${ }^{23}$ SANTOS, Paulo de Tarso. O diálogo no Grande Sertão: Veredas, 1978.
} 
relativa às suas predisposições quanto ao diálogo como espaço de convivência de um ser com outro, mas não chegamos às mesmas conclusões, visto que o autor desconsidera um elemento importante na constituição do discurso de Riobaldo, o silêncio do doutor. Para Paulo de Tarso Santos, esse doutor é o próprio autor, João Guimarães Rosa:

Para Riobaldo este enriquecimento advém, principalmente, da certeza, fortalecida no diálogo com o autor, de que o Diabo não existe. $\mathrm{O}$ "homem humano", do fim do livro, pode ser apresentado como um aspecto dessa síntese das duas culturas - de Riobaldo e do autor.

Isso permite afirmar que Rosa quis privilegiar, no livro, a antropologia da convivência, ou a teoria do diálogo, como um meio de liberação interhumana (SANTOS, 1972, p. 78).

O primeiro ponto é que o "doutor" não é o autor empírico da obra, porque o pressuposto básico é o de que estamos lidando com um texto ficcional. Nisso, podemos afirmar que o que há é um "doutor" caracterizado como um representante de outra cultura, a da cidade. Tem-se que considerar a ausência de fala do "doutor" como o que ela é, ausência. Ao fazer isso, o autor não apenas constrói um personagem, mas também a estrutura da cena do diálogo, que estudaremos no próximo subcapítulo. Para fundamentarmos nossa argumentação, utilizaremos dois estudos. O primeiro é o de João Adolfo Hansen, $O$ O: A ficção da literatura em Grande Sertão: Veredas. Nele, o autor analisa os efeitos produzidos pela interação entre os dois personagens da cena do diálogo:

\footnotetext{
Confronto divertido, pois, entre o narrador sertanejo e o "senhor" culto, entre dois universos discursivos de determinação diversa - e, agora, de maneira nova, à moda - metaforicamente, aqui - do retorno do reprimido freudiano. Se as formas de enunciação são sociais — significando que, no diálogo, o falante não só responde mas incorpora, no próprio discurso, as representações sociais do receptor, orientando a fala de acordo com suas respostas, perguntas, objeções - a representação de um locutor que fala ininterruptamente por 451 páginas não é, de modo algum, acidental, mas obedece a uma tática determinada. No caso do GS:V, observa-se que o texto todo é um ato de palavra contínuo, em que a representação culta (a do "senhor") está emudecida, calada, silenciada à força: ela só é dita nos movimentos do não-dizer, só quando incorporada e deglutida é que "fala", ausência ( HANSEN, 2000, p. 47-8)
}

Isso torna o quadro discursivo da cena dramática extremamente elaborado e sua estruturação deve ser pensada como significação para compreender o que o conteúdo da obra irá transmitir. Por isso, é possível afirmar, como já demonstramos no capítulo 2, que, a partir desse momento, Guimarães Rosa inventa um narrador que faz falar na 
literatura, numa "fala inepta" (HANSEN, 2000, p. 48), um “discurso sábio" (HANSEN, 2000, p. 33).

O outro estudo é de Kathrin Rosenfield, Os descaminhos do demo: tradição e ruptura em Grande Sertão: Veredas, no qual a autora afirma que, ao identificar o "doutor" com o autor, elimina-se o lugar ficcional do interlocutor e se desestrutura a cena do diálogo e suas características como o lugar do silêncio do outro que ouve:

P. de Tarso Santos chega inclusive a eliminar o lugar ficto ocupado pelo silêncio do interlocutor, interpretando a situação dialógica de Grande Sertão: Veredas como conversa que tem lugar entre Riobaldo e seu autor. Ora, este tipo de interpretação elimina as próprias determinações da construção artística, curto-circuita o potencial significante das posições ficcionais configuradas pela construção (sintática, lexical, gráfica etc.) privilegiando o conteúdo da enunciação em detrimento de sua forma (ROSENFIELD, 1993, p. 183)

Se a autora apresenta exemplarmente o prejuízo da anulação do lugar ficcional do interlocutor na estrutura da situação dialógica, o mesmo não se consegue com os argumentos utilizados para desenvolver a figura do "doutor". Segundo Rosenfield, o "senhor" seria uma "palavra virtualmente desaprovadora" no diálogo, que é o que faz Riobaldo-narrador interromper a todo momento sua fala para corrigi-la, o que se comprovaria, por exemplo, com "falo falso", "contei mal" (ROSENFIELD, 1993, p. 184). Ao contrário, o diálogo entre o "doutor" e Riobaldo guarda as características do diálogo filosófico e, se há uma presença de negatividade nele, não é a figura do interlocutor culto como desaprovadora, já que em diversos trechos é possível observar a concordância dele:

$\mathrm{E}$ as idéias instruídas do senhor me fornecem paz. Principalmente a confirmação, que me deu, de que o Tal não existe; pois não é? ( $G S: V$, p. 34)

Ou ainda:

Amável o senhor me ouviu, minha idéia confirmou: que o Diabo não existe. Pois não? O senhor é homem soberano, circunspecto. Amigos somos. Nonada. O diabo não há! (GS:V, p. 553).

Além disso, há uma clara intenção de Riobaldo em atrair seu interlocutor para o que está contando, como quando solicita autorização para continuar narrando: 
O senhor concedendo, eu digo: para pensar longe, sou cão mestre - o senhor solte em minha frente uma idéia ligeira, e eu rastreio essa por fundo de todos os matos, amém! (GS:V, p. 15)

Em outros momentos, até a narração parece contar com o interlocutor, mesmo que provisoriamente:

Estou contando fora, coisas divagadas. No senhor me fio? Até-que, até-que. Diga o anjo-da-guarda... (GS:V, p. 21)

Riobaldo gaba a instrução do "doutor", mesmo que ela sirva principalmente para comprovar sua própria opinião de que o diabo não existe:

Se vê que o senhor sabe muito, em idéia firme, além de ter carta de doutor. (GS:V, p. 25)

Além disso, ele demonstra apreciar um homem como o seu interlocutor:

O senhor mais queira saber? Não. Eu sabia que não. Menos mortandades. Aprecio uns assim feito o senhor - homem sagaz solerte (GS:V, p. 209210).

Por fim, Riobaldo acaba confraternizando com o doutor:

$$
\text { O senhor reza comigo. A qualquer oração. ( } G S: V, \text { p. 442) }
$$

Em conclusão, se Paulo de Tarso desconsidera a importância do "doutor" na estruturação da obra, Rosenfield não leva em conta a aproximação entre os interlocutores também como pré-requisito para a estrutura do diálogo como convivência. Mas a situação não se resolve apenas com isso, porque é preciso considerar as diversas interrupções da fala do narrador e a constante reatualização do discurso. Isso acontece por causa da distância entre Riobaldo, velho, e os fatos narrados e da sua busca pela verdade do passado. A partir do ato da enunciação em que é só lembrança, não é o suposto fato do vivido em si, pois se constitui como imagem produzida e misturada com muita imaginação. Contudo, esse assunto será tratado no último subcapítulo deste trabalho, quando analisaremos a formação da figura do narrador e suas implicações para a organização da obra e as funções temporais decorrentes dela. 


\section{O ethos do narrador na estrutura da cena do diálogo}

Em Grande Sertão: Veredas, a estruturação da cena inicial, organizada a partir da fala do narrador, é constituída de dois gêneros: o diálogo e o monólogo. Eles se entrecruzam o tempo todo durante a narração ininterrupta de Riobaldo. Neste estudo, analisaremos como é construída essa estrutura que chamaremos de cena dramática da enunciação e as temporalidades que surgem do seu tipo particular de organização e que se devem ao ethos do narrador como sujeito da dúvida.

O romance de Guimarães Rosa começa com uma marca tipográfica importante para entendermos a constituição da cena dialógica inaugural:

\section{— Nonada. Tiros que o senhor ouviu... (GS:V, p. 5)}

O travessão põe em cena o diálogo. Corrobora a constituição desse gênero o fato de o interlocutor estar explicitamente marcado, "senhor". Contudo, se continuamos a leitura do livro, na página seguinte segue-se a narração de Riobaldo, até a página 553, com a última palavra de seu discurso, "Travessia”. Fala sem parar ao mesmo tempo em que insere seu interlocutor em seu discurso inaugurado por um travessão. Essas características fazem da armação do livro uma aparente mixórdia dos gêneros dramático e épico. Por outro lado, caso não tivéssemos o destinatário marcado explicitamente, poderíamos denominar a ininterrupta enunciação de Riobaldo como um monólogo, posto que, depois da presença do primeiro travessão, antes da palavra "Nonada", não há nenhum outro que marque uma resposta do "doutor". Tipograficamente, a falta do travessão de resposta caracteriza o texto como um monólogo.

Essa estrutura, a cena dramática da enunciação, ao apresentar uma mistura dos gêneros dramático e épico, caracteriza toda a forma de enunciação e organização do romance e, a partir dela, são engendradas temporalidades importantes para a compreensão da construção ficcional da figura do narrador, produzida a partir de seus discursos. Para desenvolvermos esse assunto, estudaremos, inicialmente, as características desses dois gêneros. O primeiro, o drama, organiza-se da presença das duas personagens, atores da cena, que são o Riobaldo-narrador, velho barranqueiro, e o "senhor" ou "doutor". O segundo gênero, o épico, aparece com a rememoração do narrador das aventuras da personagem Riobaldo como jagunço, professor, suposto pactário e chefe. Os dois planos, o do drama e o do épos, são cruzados e recruzados 
durante a fala sem pausa de Riobaldo-narrador. Esses dois planos foram objeto de estudo de Evelina Hoisel no seu ensaio denominado "Elementos dramáticos da estrutura de Grande Sertão: Veredas" ${ }^{24}$. Segundo a autora, a estrutura do romance se constrói a partir desses dois planos, o que configura a cena dramática de enunciação.

A escritura de Grande Sertão: Veredas se configura como um entre-espaço, um entre-lugar (milieu) que se organiza através de um jogo textual e relacional de dois planos, de duas cenas que se interpenetram e se implicam mutuamente (HOISEL, 1991, p. 478)

Deles, surge a mixórdia dos gêneros:

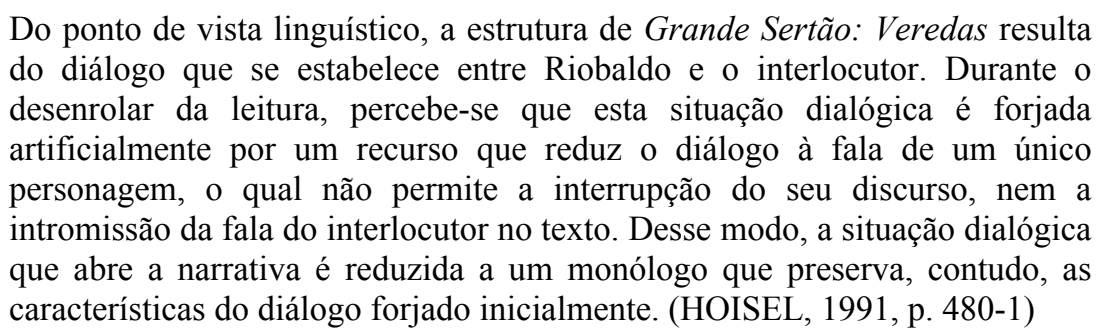

Há, portanto, uma relativização do monólogo - caracterizado pela longa fala de Riobaldo - a partir do momento em que surge a situação dialógica. A principal característica do gênero dramático é a marca temporal carregada por ele, que é o presente. $\mathrm{O}$ drama põe em cena os personagens agindo e, a partir dessa ação, engendra $\mathrm{O}$ presente $^{25}$. Assim, quando afirmamos que Riobaldo é um ator na cena dramática de enunciação, afirmamos, por consequência, que é ele quem engendra o tempo do presente a partir da sua ação, que, nesse contexto, se refere à narração. Essa ação de narrar é produzida a partir da enunciação do narrador. Devemos considerar mais cuidadosamente o estudo da enunciação e, para tanto, o ensaio de Benveniste denominado "O aparelho formal da enunciação" ${ }^{26}$ nos apresenta a importância dela para a estrutura do diálogo:

O que em geral caracteriza a enunciação é a acentuação da relação discursiva com o parceiro, seja este real ou imaginado, individual ou coletivo.

\footnotetext{
${ }^{24}$ Hoisel, "Elementos dramáticos da estrutura de Grande Sertão: Veredas", 1991, p. 478-490.

${ }^{25}$ SZONDI, Peter. Teoria do drama moderno, 2001, p. 32: "O decurso temporal do drama é uma sequência de presentes absolutos. Como absoluto, o próprio drama é responsável por isso; ele funda seu próprio tempo. Por esse motivo, cada momento deve conter em si o germe do futuro, deve ser 'prenhe de futuro'."

${ }^{26}$ BENVENISTE. E. "O aparelho formal da enunciação". In: Problemas de linguística geral II, 1989.
} 
Esta característica coloca necessariamente o que se pode denominar o quadro figurativo da enunciação. Como forma de discurso, a enunciação coloca duas "figuras" igualmente necessárias, uma, origem, a outra, fim da enunciação. É a estrutura do diálogo. Duas figuras na posição de parceiros são alternativamente protagonistas da enunciação. Este quadro é dado necessariamente com a definição da enunciação. (BENVENISTE, 1989, p. 87)

Vemos claramente que no diálogo as "duas figuras" assumem alternativamente a posição de protagonistas da enunciação, considerando a constante troca de turno discursivo, ou seja, a interação discursiva entre enunciador e interlocutor. Como em Grande Sertão: Veredas o narrador não cede seu lugar de fala ao outro, a troca de turno discursivo não acontece, o que destruiria o quadro figurativo da enunciação, responsável para a estrutura do diálogo, fazendo com que a definição de Benveniste não se aplique ao romance de Guimarães Rosa. Porém, se essa definição de diálogo não se aplica, também a de monólogo não é viável, já que há marcas do interlocutor inseridas na fala do narrador. Essa incapacidade de classificação dos elementos composicionais da obra sempre indetermina a análise crítica. Já em 1960, o crítico Roberto Schawrz se depara com a questão no seu ensaio "Grande-Sertão ${ }^{27}$ : a fala": "Sem ser rigorosamente um monólogo, não chega a diálogo" (p. 37). Desenvolvendo sua argumentação, o autor afirma:

Grande-Sertão: Veredas começa por um traço, travessão sinal colocado pelo autor para comunicar a sua ausência. O discurso que nasce irá correr ininterrupto e exclusivo até o fim do livro: sua fonte é uma personagem. Não tivéssemos mais dados, poderíamos supor um longo monólogo fictício, destinado a mostrar pelo ângulo psicológico a vida aventurosa do jagunço, tema da obra. Haveria acordo com o travessão, com a narrativa em primeira pessoa, e haveria perspectiva de uma exploração exaustiva da alma rústica. Logo as primeiras palavras, entretanto, mostram que não. Trazem à cena um interlocutor, estabelecendo uma situação dialógica. (SCHWARZ, 1981, p. 38)

Os elementos do monólogo são relativizados pela presença implícita do interlocutor, como já afirmamos, e são muito bem desenvolvidos por Schwarz. Contudo, apesar da perspicácia em apresentar a composição da cena inaugural do romance, o crítico afirma que a presença do travessão é "sinal colocado pelo autor para comunicar a sua ausência”. A afirmação é uma negação dos próprios argumentos utilizados para expor os elementos da situação dialógica, pois, como afirma o crítico, Guimarães Rosa

\footnotetext{
${ }^{27}$ SCHWARZ, Roberto. "Grande-Sertão: a fala". In: A sereia e o desconfiado. Rio de Janeiro: Ed. Paz e Terra, 1981.
} 
usa um "modo original e entranhado pelo qual obtém essa combinação dos gêneros" (SCHWARZ, 1981, p. 37). Assim, se o autor é o criador do compósito do livro, é evidente que o travessão não comunica sua ausência, sendo justamente o contrário, ele - travessão - é marca tipográfica e caracteriza a presença do autor no ato de organização dos elementos que constituem a composição entre monólogo e diálogo na fala do narrador. Além disso, outro fato que corrobora a presença do autor na utilização do travessão é que ele reafirma a mímese do relato de Riobaldo como fala, expressão da oralidade, característica fundamental para o estudo do livro. Outro signo da presença do autor é o sinal de infinito posto depois do último termo do texto, "Travessia". Os sinais tipográficos, característicos dos textos escritos, são estudados no livro $O$ discurso oral em Grande Sertão: Veredas, de Teresinha Souto Ward. A autora, quando estuda o discurso no romance de Guimarães Rosa no capítulo II, apresenta alguns recursos utilizados por ele para a constituição da oralidade do texto:

\begin{abstract}
As sentenças curtas e a intensidade do uso da vírgula reduzem a rapidez da leitura e ajudam a criar o ritmo sincopado característico da prosa roseana. Os dois pontos e o travessão sugerem pausa e entonação; os dois pontos ocasionalmente substituem verbos introdutórios como pensar, dizer, falar ou aconselhar, enquanto que o travessão indica a presença de discurso citado geralmente encaixado no texto ou introduz comentários [...] A reticência, também frequente, realça esse tipo de discurso ambíguo em que as frases como que terminam no ar ou não terminam. Abundam ainda as interrogações (retóricas de Riobaldo a si mesmo e ao ouvinte) e as exclamações, elementos marcadores da oralidade do texto (WARD, 1984, p. 81).
\end{abstract}

Apesar de o sinal do travessão ser estudado fora do contexto que propomos analisar, é significativa a citação, por lidar com o cerne da discussão, que é a representação da oralidade no texto escrito. Esta acontece por meio dos recursos gráficos (aspas, dois pontos, reticências, travessões) organizados estilisticamente pelo autor. Dessa maneira, o travessão inicial, que inaugura a fala de Riobaldo, comunica a presença criativa do autor. Isso posto, é essencial do estudo de Schwarz a exposição dos elementos que constituem o que chamamos de cena dramática da enunciação.

Nos jogos do tempo, a fala de Riobaldo ocorre no presente e nela conflui a fala implícita do doutor. Esse presente só existe pelo agora do leitor, ou seja, pelo momento da leitura. Dessa maneira, a cena do diálogo é fruto da atualização da enunciação do narrador por parte do leitor: no momento da leitura, o leitor lê o enunciado de Riobaldonarrador, que é enunciação dos acontecimentos de seu passado e dos enunciados de seus companheiros. O leitor lê também, implicitamente, o enunciado do doutor da cidade, 
que é, como já mencionado, reproduzido na enunciação do narrador. Quando o narrador fala, ele se insere no mundo junto com suas lembranças, instaurando a categoria do presente. Essa inserção surge, obrigatoriamente, da enunciação, como afirma Benveniste (1989, p. 85-6):

Da enunciação procede a instauração da categoria do presente, e da categoria do presente nasce o tempo. O presente é propriamente a origem do tempo. Ele é esta presença no mundo que somente o ato de enunciação torna possível, porque, é necessário refletir bem sobre isso, o homem não dispõe de nenhum outro meio de viver o "agora" e de torná-lo atual senão relativizando-o pela inserção do discurso no mundo.

O discurso de Riobaldo começa a fazer parte do mundo e do "agora", do presente, quando produz seu enunciado, ou seja, na fala, na enunciação. Com isso, ele se insere no mundo e se afirma como ser. Além disso, Riobaldo é um comentador de discursos alheios e para isso ele relembra. É por meio da rememoração que ele produz fatos de sua vida como jagunço, como chefe de bando, como professor, como estudante e também os fatos das vidas de outros jagunços. Dessa forma, é da fala, no presente da enunciação do narrador-Riobaldo, que nasce o passado. E também é no momento em que o narrador reflete sobre o que ocorreu, questionando o vivido, que ele estabelece o tempo do futuro como expectativa. Assim, é da enunciação (tempo presente) que nascem as outras duas categorias temporais do livro: o passado como rememoração e o futuro como expectativa.

Simultaneamente, a cena do drama é palco para a cena do epos, na qual Riobaldo assume o papel de personagem narrador. No gênero épico estão os fatos da vida do narrador, que são efetuados pela enunciação construída com a memória produtora do enunciado. Esse gênero pressupõe e engendra, portanto, o tempo do passado. Há em jogo duas temporalidades se interligando, sendo o presente da enunciação e o passado, do enunciado. Contudo, para que a narração ocorra, é preciso que haja aceitação dos dois atores da enunciação em participar do diálogo. Daí a importância do que afirmamos na primeira parte deste capítulo, ou seja, a constituição de um espaço e tempo que possibilitem a tranquilidade para a realização do diálogo, que é emulação dos diálogos platônicos. Por isso, ao relacionar em seu estudo elementos da "antropologia de convivência" com os da estrutura, Paulo de Tarso Santos vai ao cerne da discussão: 
Apresentada, formalmente, como longo monólogo de Riobaldo, a trama literária do Grande Sertão envolve, na verdade, um claro diálogo do personagem-símbolo com o autor da obra. Rosa não fala, mas sua palavra, expressão erudita de sua cultura, aparece sintetizada nas falas de Riobaldo, criando um filão que permite falar de uma antropologia da convivência, ou de uma antropologia cultural no Grande Sertão. (SANTOS, 1978, p. 11)

A definição da estrutura como dialógica tem importância para que haja uma interação entre a cultura da cidade e a do sertão. Para tanto, é preciso a constituição de um narrador verossímil e que consiga atrair seu interlocutor imediato, o "doutor". Por isso, o narrador apoia o início de sua narração numa suposta sinceridade a fim de criar o clima descontraído de uma conversa entre dois amigos. O objetivo dessa conversa é receber ajuda do "senhor" e, para isso, Riobaldo conta com a perspicácia de seu interlocutor para conseguir o que quer (a afirmação de que o diabo não existe) e para isso elogia suas qualidades, enquanto mostra sua modéstia: "Sou só um sertanejo, nessas altas idéias navego mal. Sou muito pobre coitado. Inveja minha pura é de uns conforme o senhor, com toda a leitura e suma doutoração" (GS:V, p. 11). Contudo, isso é logo relativizado, pois Riobaldo é um jagunço-letrado:

Não que eu esteja analfabeto. Soletrei, anos e meio, meante cartilha, memória e palmatória. Tive mestre, Mestre Lucas, no Curralinho, decorei gramática, as operações, regra-de-três, até geografia e estudo pátrio. Em folhas grande de papel, com capricho tracei bonitos mapas. (GS:V, p. 11)

Essa aproximação, tendo como base a falsa modéstia, tem dupla serventia na elaboração da cena dramática de enunciação, que é explicitada por Teresinha Ward:

\begin{abstract}
A atitude em relação ao ouvinte serve para convencê-lo coagi-lo a permanecer em sua fazenda e ouvir a sua estória, mas funciona, como já mencionado, como estratégia na configuração de um mediador que seja aceitável para o público leitor e com o qual possa identificar-se. (WARD, 1984, p. 122)
\end{abstract}

A primeira consequência da atitude do narrador é a mesma de que já tratamos acima com relação ao ambiente e à atmosfera do diálogo filosófico. Já na segunda, é preciso maior cuidado, pois entramos no campo da recepção da obra literária, na constituição de um leitor implícito. Essa identificação do leitor com o "doutor" é possível porque, no nível do discurso, o interlocutor é constituído como um representante da cultura letrada, dita culta, da elite intelectual que julgará o livro de acordo com seus padrões críticos. Mas, em outro plano, o autor, por ter elaborado seu 
narrador como letrado e conhecedor da cultura do sertão, subjuga a cultura letrada, ou seja, avalia o doutor. Por isso, Riobaldo constantemente se refere à importância da experiência empírica, como quando define o sertão:

Como vou achar ordem para dizer ao senhor a continuação do martírio, em desde que as barras quebraram, no seguinte, na brumalva daquele falecido amanhecer, sem esperança em uma, sem o simples de passarinhos faltantes? $(G S: V$, p. 44)

O doutor não vivenciou as experiências do narrador:

\begin{abstract}
O senhor viu onça: boca de lado e lado, raivável, pelos filhos? Viu rusgo de touro no alto campo, brabejando; cobra jararacussú emendando sete botes estalados; bando dôido de queixadas se passantes, dando febre no mato? E o senhor não viu o Reinaldo guerrear!... Essas coisas se acreditam. (GS:V, p. 144)
\end{abstract}

Argumentando dessa forma, o narrador submete a cultura letrada do "doutor" à sua artimanha narrativa. Nesse aspecto, há essa identificação apontada por Teresinha Souto entre o leitor empírico, aquele que lerá o livro, e o "doutor". Mas é fundamental considerar a obra literária como ficção e, nesse aspecto, o leitor implícito é um ator da cena dramática e possui papel importante na sua constituição, porque a partir da sua presença instauram-se duas temporalidades: o tempo de leitura e o tempo de narração. Esse último é o já mencionado presente da enunciação, que coloca em cena o diálogo entre os dois atores: Riobaldo e o "doutor". Como vimos no final do primeiro capítulo deste estudo, o leitor implícito é constituído "na estrutura do texto" (ISER, 1996, p. 73). No caso de Grande Sertão: Veredas, o leitor implícito prefigura uma imagem hipotética dos possíveis leitores empíricos. O tempo de leitura depende, obviamente, da velocidade e da capacidade de compreensão de cada leitor, mas o importante é que a prefiguração de um leitor implícito, como elaborada no romance de Guimarães Rosa, é política, como vimos no segundo capítulo, com a análise da época literária da publicação do livro na interpretação de Hansen.

É importante reforçar que o leitor implícito é parte da obra e está inserido nela no presente da enunciação, que é distinto do presente empírico, que só existe quando o leitor age como atualizador do livro por meio da leitura. O leitor empírico não ocupa o lugar do "doutor", visto que este surge a partir da fala do narrador, como demonstra Kathrin Rosenfield (1993, p. 180): 
Estritamente falando, nem Riobaldo nem o senhor existem, Riobaldo não fala, nem rememora, nem reflete, mas surge - como o senhor também enquanto projeção de um discurso que lhe é atribuído pelo autor.

Essa afirmação de Rosenfield, além de demonstrar o poder do discurso, do ato de fala, da narração, vem corroborar o que defendemos acima, ou seja, que o signo tipográfico inaugural da cena de enunciação que instaura a estrutura mista de diálogo/monólogo (travessão) marca a presença criativa do autor.

Definido o primeiro ator da enunciação, isso é, o “doutor" (leitor implícito), é preciso estudar o outro, ou seja, a constituição da figura do narrador. Como vimos, ele é um narrador letrado, mas que vai além, pois demonstra ser conhecedor também da cultura do sertão:

Sertão. O senhor sabe: sertão é onde manda quem é forte, com as astúcias. Deus mesmo, quando vier, que venha armado! E bala é um pedacinhozinho de metal... (GS:V, p. 15)

O narrador apresenta definições para o sertão que não lidam apenas com conceitos geográficos de lugares (embora eles sejam relatados com tamanha precisão que lembram uma descrição realista ${ }^{28}$ ), mas sim de um Sertão que é parte daquele que lá nasceu e viveu: um sertão que forma a pessoa e a pessoa que forma o sertão: "Sertão. Sabe o senhor: sertão é onde o pensamento da gente se forma mais forte do que o poder do lugar" (GS:V, p. 21). Nasce, assim, um sertão místico e mítico. O primeiro surge do “contemplar objetivamente o incompreensível"; já o segundo, principalmente, do suposto pacto com o diabo, cuja dívida é paga com a alma do narrador. Sua angústia é o medo de perder a alma, o medo do futuro. Por isso precisa da ajuda do doutor, de seu interlocutor, para confirmar a inexistência do demo e cancelar o pacto:

E as idéias instruídas do senhor me fornecem paz. Principalmente a confirmação, que me deu, de que o Tal não existe; pois é não? O Arrenegado, o Cão, o Cramulhão, o Indivíduo, o Galhardo, o Pé-de-Pato, o Sujo, o Homem, o Tisnado, o Côxo, o Temba, o Azarape, o Coisa-Ruim, o Mafarro, o Pé-Preto, o Canho, o Duba-Dubá, o Rapaz, o Tristonho, o Não-sei-quediga, O-que-nunca-se-ri, o Sem-Gracejos... Pois, não existe! E, se não existe, como é que se pode se contratar pacto com ele? (GS:V, p. 34)

\footnotetext{
${ }^{28}$ Por exemplo, a seguinte descrição de um começo de chuva no Guararavacã do Guiacuí: "Daí, deu um sutil trovão. Trovejou-se, outro. As tanajuras revoaram. Bateu o primeiro toró de chuva. Cortamos paus, folhagem de coqueiros, aumentamos o rancho" (GS:V, p. 268).
} 
O conteúdo dialógico e diabólico de Grande Sertão: Veredas serve para que o narrador consiga, pela palavra, sua redenção. O diálogo é palco dos fatos da vida do jagunço-Riobaldo, que fez um suposto pacto com o diabo, para conseguir dominar o poder do imaginário do sertão. Na busca e na ida às Veredas-Mortas, encontra a força desse imaginário. No momento em que narra, o fazendeiro é sujeito da dúvida, pois não é possível confirmar a existência do diabo e a validade do pacto. Talvez seja por isso que ele fale tanto, como ele próprio diz: "Mire veja: o que é ruim, dentro da gente, a gente perverte sempre por arredar mais de si. Para isso é que o muito se fala?" (GS:V,p. $34)$.

Sendo cindido, pertencendo tanto ao mundo letrado como mundo sertanejo, Riobaldo faz a união entre as duas culturas excluindo o pitoresco. O narrador, assim constituído, expressa a literatura do sertão, com a linguagem e a visão de dentro do sertão. Por isso, Hansen afirma que

[...]pela primeira vez, em Grande Sertão: Veredas falam as linguagens do mato, sem mediação de um narrador ilustrado que, na ficção brasileira, sempre usurpou o lugar de fala do sertanejo, quando o constituiu como natureza, idílica ou decaída, como outro inalcançável ou a ser convertido, ou, ainda, com outro tristemente alienado nas garras do capital, nas belas sínteses ideais de Alencar, na tolice naturalista, na força comovente e espantosa de Euclides, na amargura pessimista deste admirável Graciliano. (HANSEN, 2000, p. 191)

Esse narrador dividido entre duas culturas também foi assim definido por Walnice Galvão:

Fica eliminado o contraste canhestro, tão praticado pela prosa regionalista, entre o diálogo que reproduz o falar e o não-diálogo que reproduz a prática letrada do autor. Destarte, o diálogo deixa de incrustar-se no texto como um objeto folclórico, exibido à apreciação do pitoresco (GALVÃO, 1972, p. 71)

O diálogo agora não é mais produzido por um narrador como o de Euclides ou Graciliano Ramos, mas sim por um que emerge da cultura e da história do sertão. Assim, junto à história da sua vida de andanças épicas, surge a cultura do sertão relatada por Riobaldo, que passa em revista a cultura do litoral. Essa análise da cultura da cidade surge nas falas de Riobaldo quando, ao elogiar o doutor, também o põe em seu lugar: “O senhor é de fora, meu amigo mas meu estranho" (GS:V, p. 34). Porém, Riobaldo quer conversar com o doutor para que ele lhe confirme a não-existência do Diabo para isso elogia sua ilustração: "Inveja minha pura é de uns conforme o senhor, com 
toda leitura e suma doutoração" (GS:V, p. 11). Além disso, elogia a capacidade de "saber ouvir" do doutor: "O senhor é bondoso de me ouvir. Tem horas antigas que ficaram muito mais perto da gente do que outras, de recente data. $\mathrm{O}$ senhor mesmo sabe" (GS:V, p. 89). Entretanto, esse saber do doutor não impede que o narrador o ensine sobre a maneira de compreender o que é narrado: "Eu sei que isto que estou dizendo é dificultoso, muito entrançado. Mas o senhor vai avante" ( $G S: V$, p. 90). O velho fazendeiro, portanto, ao mesmo tempo em que elogia as qualidades do doutor, também lhe impõe um lugar de silêncio, como lugar de ouvinte, e relativiza algumas das qualidades:

\begin{abstract}
Alguns de seus repetidos elogios à capacitação do interlocutor têm muito de manha rústica, que exagera para pôr no seu devido lugar, para reduzir a proporções mais razoáveis. Por isso, seus louvores se entremeiam de reivindicações quanto à posse e intransmissibilidade da experiência; a experiência é dêle, não do interlocutor (GALVÃO, 1972, p. 83)
\end{abstract}

Ainda no nível do enunciado, dos fatos narrados, Riobaldo dá a entender que já contou sua história a duas outras pessoas. A primeira a ouvi-lo foi Zé Bebelo:

Três dias falhei com ele, lá, no Porto-Passarinho. [...] Mas, naqueles três dias, não descansou de querer me aliviar, e de formar outros planejamentos para encaminhar minha vida. Nem indenizar completa a minha dôr maior ele não pudesse. Só que Zé Bebelo não era homem de não prosseguir. Do que a Deus dou graças! (GS:V, p. 551-2)

Após esses três dias, que também é o tempo gasto para contar a história ao doutor, Riobaldo deu "graças" porque Zé Bebelo escreveu um bilhete e o mandou para a outra pessoa que ouviria sua história, o compadre Quelemém de Góis:

Tinha de ser Zé Bebelo, para isso. Só Zé Bebelo, mesmo, para meu destino começar de salvar. Porque o bilhete era para o Compadre meu Quelemém de Góis, na Jijujã — Vereda do Burití Pardo.

$[\ldots]$

Compadre meu Quelemém me hospedou, deixou meu contar minha história inteira. Como vi que ele me olhava com aquela enorme paciência - calma de que minha dôr passasse; e que podia esperar muito longo tempo. O que vendo, tive vergonha, assaz. ( $G S: V$, p. 552)

O objetivo em todos os três relatos é o mesmo, isso é, saber se o diabo existe ou não, o que comprova ou anula a existência do pacto: “- 'O senhor acha que a minha alma eu vendi, pactário?!"” (GS:V, p. 552). Há resposta de duas pessoas: uma é explícita, a outra, implícita, o que comprova a existência do diálogo nos dois níveis 
discursivos - enunciação (com o doutor) e enunciado (com o compadre Quelemém). O compadre responde-lhe: “— 'Tem cisma não. Pensa para diante. Comprar ou vender, às vezes, são as ações que são as quase iguais..." (p. 552). Já o “doutor" responde implicitamente pela voz do narrador:

Amável o senhor me ouviu, minha idéia confirmou: que o Diabo não existe. Pois não? O senhor é um homem soberano, circunspecto. Amigos somos. Nonada. O diabo não há! É o que eu digo, se for... Existe é homem humano. Travessia. (GS:V, p. 553)

A confirmação da não-existência do demo é comprovação da amizade entre ambos. Nas duas respostas, é possível visualizar a busca de outro sentido para as coisas. Eis o motivo de a resposta do compadre Quelemém não ser simplesmente um "sim" ou um "não", pois ele vê além da dualidade bem/mal:

O senhor tolere minhas más devassas no contar. É ignorância. Eu não converso com ninguém de fora, quase. Não sei contar direito. Aprendi um pouco foi com o compadre meu Quelemém; mas ele quer saber tudo diverso: quer não é o caso inteirado em si, mas a sobre-coisa. (GS:V, p. 180)

Guimarães Rosa trabalha de forma divertida nesse trecho, pois lida com a ambiguidade de maneira magistral. Ao mostrar ao doutor que seu contar é desconexo, o narrador se desculpa e diz não saber contar direito, mas logo em seguida afirma que aprendeu um pouco com seu compadre Quelemém que, como Riobaldo, busca algo mais do que o exato da coisa, busca o "diverso", "a sobre-coisa". Confirma quando afirma que a matéria e o propósito da narração exigem a complexidade do modo de contar:

Contar seguido, alinhavado, só mesmo sendo as coisas de rasa importância. De cada vivimento que eu real tive, de alegria forte ou pesar, cada vez daquela hoje vejo que eu era como se fosse diferente pessoa. Sucedido desgovernado. Assim eu acho, assim é que eu conto. (GS: $V$, p. 88-9)

A busca pelo incompreensível só é possível quando se tem liberdade, por isso, segundo Nelly Novaes Coelho, o autor formalmente criou um monólogo, mas cujo conteúdo é dialogante, pois assim, na confluência ininterrupta entre o dramático e o épico, mimetiza-se a aparente falta de forma e a liberdade da fala na conversa cotidiana, que não se preocupa com gêneros: 
O processo do "monólogo interior" (que fecha o personagem no círculo de sua própria experiência, em sondagem introspectiva) amplia-se no "estilo dialogante" ou "interrogativo" (um "eu" que se dirige a um "tu", que permanece fora da narrativa) estilo que abre para o narrador o espaço da liberdade criadora. ${ }^{29}$

A enunciação, que produz enunciados como esforço de memória e que comenta esses enunciados invalidando-os, mantém o interlocutor em constante suspensão, por isso a preocupação do narrador em querer saber o impacto que suas palavras causam no “doutor”. O interlocutor também age no presente e sua intervenção é percebida pelo leitor quando Riobaldo a enuncia nas possíveis perguntas, respostas e reações do doutor, como na primeira página do livro: "O senhor ri certas risadas" (GS:V, p. 5). Pressupõese que o interlocutor ri da crendice popular quando Riobaldo relata o caso do bezerro erroso. Citando mais um exemplo entre vários, percebemos uma resposta dada pelo doutor ao narrador, quando questionado sobre sua crença na existência do diabo: "Mas, não me diga que o senhor, assisado e instruído, que acredita na pessoa dele?! Não? Lhe agradeço! Sua alta opinião compõe minha valia" (GS:V, p. 7). Ou quando o narrador dá a entender que o doutor fez uma pergunta e a reproduz: "E o 'Urutú-Branco'? Ah, não me fale. Ah, esse... tristonho levado, que foi - que era um pobre menino do destino" ( $G S: V$, p. 14). Além da pergunta, nesse caso há também as aspas em "Urutú-Branco", que, como se sabe, servem tipograficamente para mostrar o discurso de outrem.

Todo o jogo entre o tempo da enunciação e o do enunciado só é possível porque o narrador se define como sujeito da dúvida. Este estudo exige a inclusão de novas interpretações, que se baseiam na distinção das temporalidades existentes na enunciação e no enunciado. Nessa mesma linha de reflexão, temos os tempos do narrar e do comentar, que constituem a tessitura do tempo da narrativa. Benedito Nunes, num ensaio chamado "Literatura e filosofia: (Grande sertão: veredas)", apresenta a divisão do tempo da narrativa no romance de Guimarães Rosa em três unidades:

[...] o tempo da narrativa se desenvolve em três unidades temporais distintas: a unidade correspondente ao relato oral que está sendo feito (presente), a unidade dos acontecimentos épicos (passado), e a unidade correspondente às lembranças evocadas (presente-passado). (NUNES, 1983, p. 202-3)

Das três unidades temporais apresentadas por Nunes, já estudamos a primeira (correspondente ao presente da enunciação) e a segunda (correspondente ao passado do

\footnotetext{
${ }^{29}$ COELHO, Nelly Novaes. Suplemento de O Estado de S. Paulo, 1974.
} 
enunciado). Falta-nos o estudo da terceira, mas que estabelecemos como pressuposto da constituição da figura do narrador. Para tanto, é preciso analisar o tempo do narrar e o do comentar, que implicam os tempos do enunciado e da enunciação, ou seja, passado e presente. Como os dois tempos se implicam mutuamente, Riobaldo narra comentando e comenta narrando. O narrar e o comentar possuem as mesmas características temporais da enunciação e do enunciado, respectivamente. Assim também acontece com a divisão entre os planos que Cavalcanti Proença apresenta no seu livro Trilhas do Grande Sertão para estudar os aspectos estruturais, os elementos míticos, a efabulação do romance e o léxico. Segundo ele, inicialmente, há dois planos em Grande Sertão: Veredas. O primeiro é subjetivo, enquanto que o segundo corresponde ao campo mítico. Assim, divide seu estudo em duas partes. A primeira versa sobre o plano subjetivo, que estrutura o romance de Guimarães Rosa, e que, novamente, divide-se em duas linhas de estudo: uma objetiva e a outra subjetiva. Fazem parte da primeira linha "os combates e andanças" do jagunço Riobaldo. Enquanto que a segunda focaliza o que Proença chamou de "marchas e contramarchas de um espírito estranhamente místico, oscilando entre Deus e o Diabo" (PROENÇA, s/d, p. 6).

Os dois planos se entrecruzam e são superpostos, criando a trama de efabulação do romance. Para demonstrar a exegese da efabulação, Cavalcanti Proença propõe outra divisão, agora em três partes: individual, coletiva e telúrica. A primeira liga-se àquela segunda do plano subjetivo, cujo conteúdo é o "antagonismo entre os elementos da alma humana" (PROENÇA, s/d, p. 9). A segunda, coletiva, acrescenta informações à primeira do plano subjetivo, pois trata do estilo de Guimarães Rosa, isso é, a estilização que o autor faz da tradição cultural, cujo símile é o herói medieval, agora "aculturado nos sertões do Brasil Central” (PROENÇA, s/d, p. 9). Já a última, telúrica, personifica os elementos naturais, como sertão, vento, rio, buritis etc.

É importante ressaltar disso as duas linhas de estudo. A primeira, subjetiva, responsável pela autocrítica de Riobaldo, o seu comentar, o questionamento infindável de todas as coisas, a produção de indeterminações, ambiguidades, paradoxos, enfim, responsável pelo espírito crítico que fundamenta um diálogo filosófico, como um Sócrates sertanejo. A segunda, objetiva, abarca as aventuras de Riobaldo como personagem e, como já demonstramos no subcapítulo anterior com as citações de Cavalcanti Proença, trata-se da parte coletiva, das andanças do protagonista pelo sertão, misturadas com muito romance de cavalaria. Essas duas linhas de estudo foram 
aprofundadas por José Carlos Garbuglio no seu estudo "O mundo movente", presente no livro Rosa em dois tempos ${ }^{30}$. Nele, o autor as define assim:

\begin{abstract}
A linha objetiva trata dos fatos em sentido diacrônico, acompanhando a sucessão dos acontecimentos que aparecem de maneira fracionária e aparentemente os tumultua e lhe dificulta a ordenação. A subjetiva os vê e analisa em sentido sincrônico, buscando penetrar no fundo das causas e consequências dos acontecimentos. Por isso, se pode falar numa linha horizontal ou horizontalizável, onde estão contidos os sucessos e numa linha vertical onde se processa a especulação desses fatos. A primeira é expositiva, a segunda de natureza crítica. (GARBUGLIO, 2005, p. 10)
\end{abstract}

A perspectiva objetiva surge da narração dos acontecimentos. É na linha objetiva, portanto, que confluem enunciação e enunciado. A primeira é caracterizada pela fala do narrador; a segunda, pelo produto dessa fala. Ambas estão ligadas e são dependentes uma da outra. A perspectiva subjetiva é aquela em que o narrador reflete sobre os fatos narrados e pertence à enunciação: ela é presente, embora sua origem esteja no passado. Como disse Garbuglio, a linha subjetiva é reflexiva e um dos exemplos mais célebres dela é quando Riobaldo faz a distinção de seu próprio ser:

De tudo não falo. Não tenciono relatar ao senhor minha vida em dobrados passos; servia para que? Quero é armar o ponto dum fato, para depois lhe pedir um conselho. Por daí, então, careço de que o senhor escute bem essas passagens: da vida de Riobaldo, o jagunço. Narrei miúdo, desse dia, dessa noite, que dela nunca posso achar o esquecimento. O jagunço Riobaldo. Fui eu? Fui e não fui. Não fui! - porque não sou, não quero ser. Deus esteja! $(G S: V$, p. 197)

Ao distinguir aquele ser do passado (jagunço) desse do presente (velho barranqueiro), faz-se também a separação entre o que Garbuglio chamou de o homo actuandi e o homo cogitandi. O primeiro é o Riobaldo das andanças, das aventuras, por fim, o que age e que pertence ao épos. O segundo é o narrador, velho barranqueiro, suposto pactário e fazendeiro. Notemos que os verbos que se referem à vida do jagunço estão no pretérito perfeito, sugerindo a ideia de que ele está realmente acabado: "Narrei miúdo...”, “Fui eu? Fui e não fui. Não fui!”. Já a reflexão, o comentário, trazem a ação da narrativa para o presente, pois fazem parte do momento da enunciação. No presente, o narrador sofre com três dúvidas essenciais. A primeira é a do pacto, que o leva à aporia do ser e do não-ser. Em outras palavras, no momento em que narra, ao mesmo tempo em que deseja relembrar o passado, também quer alterá-lo para que sua culpa

\footnotetext{
${ }^{30}$ GARBUGLIO, José Carlos. “O mundo movente”. In: Rosa em dois tempos. São Paulo: Nankin, 2005.
} 
diminua e possa justificar suas ações. Como não é possível negá-las, nem é possível uma lembrança pura do que foi, Riobaldo é e não é o jagunço Riobaldo ao mesmo tempo. A segunda dúvida é consequência da primeira, ou seja, ser o responsável pela morte de Diadorim. Se ele, jagunço, com a força do imaginário diabólico consegue se tornar o chefe do bando e conduz todos ao Paredão para a batalha final contra os judas, e a consequência é a morte de Diadorim, sem o pacto a batalha não existiria. Portanto, o pacto representaria, como karma, destino, a morte de Diadorim. A última dúvida é a questão de ter amado um homem. Diadorim, travestido em guerreiro, Reinaldo, só se revela após morta. $\mathrm{O}$ que constitui problema é que durante toda a narrativa o narrador afirma suas angústias de tê-lo amado: "Gostava de Diadorim, dum jeito condenado; nem pensava mais que gostava, mas aí sabia que já gostava em sempre” (GS:V, p. 84). Essas três culpas - ter realizado o pacto, ter causado a morte de Diadorim e ter amado um homem - constituem o ethos do narrador.

O ethos do narrador aqui é definido de acordo com a definição do bom orador por Aristóteles. Segundo o filósofo, o bom orador é produto do seu discurso e não uma imagem pública dele constituída previamente, como defende Isócrates. Como exemplo, vejamos a tese de Dilson Ferreira, O ethos do enunciador nos romances de Machado de Assis: uma abordagem semiótica, na qual o autor diz:

[...] Aristóteles concorda com Isócrates ao afirmar que as provas resultam não apenas das demonstrações realizadas, mas principalmente das qualidades morais que se supõe que o orador deva ter (Retórica, I, VIII, VI). Assim, influenciado ou não por Isócrates, Aristóteles também dedicará especial atenção ao ethos, muito embora (e agora se chega à divergência) o entenda em uma concepção bastante distinta da de Isócrates: o ethos não será mais fruto da imagem pública do orador, exterior ao discurso, mas construído por ele. Não será decorrente dos discursos sobre o enunciador, mas do efeito produzido por sua enunciação. A diferença é sutil: viu-se que para Isócrates os atributos morais do orador e a qualidade do discurso andam juntos, sendo que os primeiros o habilitam a construir o segundo. Em Aristóteles, de certa forma, as qualidades do orador e do discurso também andam juntas, mas há uma inversão importante: aquelas são construídas por este. É o bom discurso que constrói o bom orador e não o contrário. (FERREIRA, 2006, p. 18)

O ethos do narrador de Grande Sertão: Veredas é definido a partir das três culpas que o constituem como sujeito, pois, como afirmou Rosenfield, Riobaldonarrador surge do seu discurso. Este é baseado constantemente no paradoxo, no nonsense, o que pode ser visto nas afirmações simultâneas de Verdadeiro e de Falso, de ser e de não-ser. As três dúvidas, que constituem o narrador como sujeito que afirma e 
nega ao mesmo tempo, espalham por toda a sua fala outras formas de negatividade, ambigüidade e paradoxo, como a dúvida de pertencer a algum grupo:

Eu, quem é que eu era? De que lado eu era? Zé Bebelo ou Joca Ramiro? Titão Passos... o Reinaldo... (GS:V, p. 137)

Ou a de se Deus e o Diabo existem:

Deus existe mesmo quando não há. Mas o demônio não precisa de existir para haver. $(G S: V$, p. 53)

Como Riobaldo é sujeito dividido, seu discurso reflete essa característica na forma como é organizado, porque se o narrador tem dúvidas de como ele era no passado e do seu ser, no presente, enquanto narra, elas permanecem. Um exemplo é a sua raiva em relação ao Hermógenes:

Quando ele vinha conversar comigo, no silêncio da minha raiva eu pedia até ao demônio para vir ficar de permeio entre nós dois, para dele me apartar. Eu podia rechear de balas aquele nagã próprio, e descarregar nele tiros, entre os todos olhos. O senhor tolere e releve estas palavras minhas de fúria; mas, disto, sei, era assim que eu sentia, sofria. Eu era assim. Hoje em dia, nem sei se sou assim mais. (GS:V, p. 171) (grifo meu)

A forma de seu discurso é um reflexo de como ele era e de como ele é:

Contar seguido, alinhavado, só mesmo sendo as coisas de rasa importância. De cada vivimento que eu real tive, de alegria forte ou pesar, cada vez daquela hoje vejo que eu era como se fosse diferente pessoa. Sucedido desgovernado. Assim eu acho, assim é que eu conto. (GS:V, p. 88-9) (grifos meus)

A estrutura da cena dramática da enunciação entre os gêneros de diálogo e de monólogo representa, alegoricamente, a própria constituição da figura do narrador, que é definida por ser e não-ser e, simultaneamente, pelo nonsense, pelos paradoxos e pelas ambiguidades. Essas características, que não consideram o princípio do terceiro excluído, lançam fora a lógica aristotélica e põem em cena temporalidades importantes, como o jogo entre o passado recuperado pelo presente apenas como imagem do que poderia ter sido. Assim, como o narrador é ambíguo, produtor de enunciados dúplices, seu ethos, isso é, o que o seu discurso projeta dele mesmo, caracteriza-o como um narrador não confiável. Isso nos leva ao último capítulo deste estudo. 


\section{Os jogos do tempo}

0 senhor pergunte: quem foi que foi que foi o jagunço Riobaldo? $^{31}$

0 meu fim evidente era atar as duas pontes da vida, e restaurar na velhice a adolescência. Pois, senhor, não consegui compor o que foi nem o que fui. Em tudo, se 0 rosto é igual, a fisionomia é diferente. Se só me faltassem os outros, vá; um homem consola-se mais ou menos das pessoas que perde; mas falto eu mesmo, e essa lacuna é tudo. ${ }^{32}$

Nosso estudo da estrutura da cena dramática teve como base a distinção entre enunciação e enunciado e as temporalidades de presente e passado que surgem na produção oral do narrador, que tem como pano de fundo o silêncio forçado de um interlocutor, cujas funções já foram explicitadas. Tomando tudo isso como pressuposto, passamos ao estudo da figura do narrador como sujeito da dúvida e, como ele é o produtor do discurso, definimos as características de seu ethos de narrador não confiável. Outros narradores não confiáveis, presentes na Literatura Brasileira, são os de Machado de Assis. Os romances que possuem esse tipo de narrador evidenciam uma particularidade comum: o jogo com o tempo do narrar e do comentar. A estrutura da narrativa normalmente é influenciada pela ordem cronológica da memória das coisas narradas, ao mesmo tempo em que o narrado e sua ordem demonstram o arbitrário da direção narrativa ou da escolha feita pelo narrador de contar os fatos que lhe são interessantes e na ordem que lhe convém. Dessa maneira, apesar de afirmarem que narram de acordo com a sequência dos momentos de que se recordam, os comentários a respeito da forma escolhida para narrar põem em suspensão a ordem do tempo da memória, para afirmar outra, a do tempo da organização da estrutura da memória. Assim, a estrutura da narração temporaliza a fala do narrador, favorecendo o arbitrário da escolha que melhor convier para a organização do texto de acordo com os efeitos pretendidos pelo autor. Por essas semelhanças, escolhemos analisar a obra Grande Sertão: Veredas tendo como suporte de comparação alguns trechos de duas obras de Machado de Assis: Dom Casmurro e Memórias póstumas de Brás Cubas. Há outras semelhanças, também importantes: a narração acontece em primeira pessoa; conta-se a

\footnotetext{
${ }^{31}$ ROSA, 2006, p. 284.

${ }^{32}$ ASSIS, Machado de Assis. Dom Casmurro. São Paulo: Círculo do Livro, 1991, p. 7.
} 
vida dos protagonistas; os três conhecem toda a história. E há também as diferenças entre elas, que explicitamos, pois são imprescindíveis para o nosso estudo. A primeira é a de que, no caso das duas obras de Machado de Assis, não lidamos com um narrador propriamente dito, mas sim com um autor fictício, já que ambos, Dom Casmurro e Brás Cubas, escrevem seus livros. No caso de Grande Sertão: Veredas, há um narrador e a escritura do livro é mimese de um relato oral. A segunda é que a estruturação do livro em Machado de Assis é feita por capítulos. Já no romance de Guimarães Rosa, a organização se furta aos capítulos, sendo um livro sem separações, o que reforça o efeito de oralidade do relato. Há outros recursos retóricos e estéticos decorrentes dessas duas diferenças, mas que serão analisados no momento oportuno.

Ao iniciar sua narração, Dom Casmurro explica o título do livro, o que caracteriza sua figura como personagem vista pelos outros: "Os vizinhos, que não gostam dos meus hábitos reclusos e calados, deram curso à alcunha, que afinal pegou" (DC, p. 5). O apelido, dado por um rapaz conhecido "de vista e de chapéu", é "Dom Casmurro", que, como explica o autor fictício:

Não consultes dicionários. Casmurro não está aqui no sentido que lhe dão, mas no de pôs o vulgo de homem calado e metido consigo. Dom veio por ironia, para atribuir-lhe fumos de fidalgo. Tudo por estar cochilando! (DC, p. 5)

Aproveitando a ironia de "dom", o autor fictício coloca a alcunha no título de seu romance e, ao fazê-lo, demonstra os princípios de arbitrariedade da escrita por meio do comentário:

Também não achei melhor título para a minha narração; se não tiver outro daqui até ao final do livro, vai este mesmo. O meu poeta do trem ficará sabendo que não lhe guardo rancor. E com pequeno esforço, sendo o título seu, poderá cuidar que a obra é sua. Há livros que apenas terão isso dos seus autores; alguns nem tanto. (DC, p. 6)

O capítulo II trata "Do livro" e nele Dom Casmurro justifica os motivos que the "põem a pena na mão" ( $D C$, p. 6). Antes, porém, apresenta sua vida atual e, nesse momento, o leitor é levado ao presente de enunciação. $\mathrm{O}$ autor vive numa casa que é a réplica daquela em que viveu com sua mãe, seu tio Cosme, a prima Justina, o agregado José Dias, e onde houve o amor da juventude pela filha do vizinho, Capitolina, Capitu. O motivo da cópia é o que está exposto na epígrafe deste subcapítulo e que reproduzimos novamente: 
O meu fim evidente era atar as duas pontes da vida, e restaurar na velhice a adolescência. Pois, senhor, não consegui compor o que foi nem o que fui. Em tudo, se o rosto é igual, a fisionomia é diferente. Se só me faltassem os outros, vá; um homem consola-se mais ou menos das pessoas que perde; mas falto eu mesmo, e essa lacuna é tudo. ( $D C$, p. 7)

Nesse trecho apresenta-se o tema do tempo. A casa que reproduz a outra é tentativa de recuperar o passado, mas o autor Bento falta a si próprio, pois, como afirma: "não consegui compor o que foi nem o que fui". Dessa forma, a réplica da casa não o ajuda a restaurar as memórias. Passa, portanto, ao seu novo projeto: escrever um livro. Contudo, não deseja trabalho, nem pesquisas áridas e então os bustos pintados nas paredes, César, Augusto, Nero e Massinissa, também réplicas de imagens da casa de Matacavalos, dizem-lhe "que, uma vez que eles não alcançam reconstituir-me os tempos idos, pegasse da pena e contasse alguns" ( $D C$, p. 7). A esperança de reconstituição do tempo passado pela narração é nova esperança: "Talvez a narração me desse a ilusão, e as sombras viessem perpassar ligeiras, como ao poeta, não o do trem, mas o do Fausto: Aí vindes outras vez, inquietas sombras...?" (DC, p. 7). A partir da enunciação, o autor fictício tem a intenção de reproduzir as memórias da sua vida e narrar quem foi Bento Santiago, mas tudo é muito irônico, porque logo em seguida afirma sua inépcia como escritor:

Sim, Nero, Augusto, Massinissa, e tu, grande César, que me incitas os meus comentários, agradeço-vos o conselho, e vou deitar ao papel as reminiscências que me vierem vindo. Deste modo, viverei o que vivi, $e$ assentarei a mão para alguma obra de maior tomo. (DC, p. 7-8)

Ao mesmo tempo em que se lança à empresa, afirma não ter capacidade ("mão") para escrever uma grande obra, o que fica prometido ao futuro, dizendo que a obra é uma tentativa, um ensaio. Ao mesmo tempo, diz querer reviver o que viveu, ou seja, resgatar o passado, o tempo perdido, pelas lembranças, rememoração e reminiscências. Tudo isso, contudo, num narrador que já afirmou ser uma lacuna, cuja parte faltante é ele mesmo. O conteúdo da história é seu amor por Capitu e, ao final, a dúvida de ter sido traído.

E bem, qualquer que seja a solução, uma cousa fica, e é a suma das sumas, ou o resto dos restos, a saber, que a minha primeira amiga e o meu maior amigo, tão extremosos ambos e tão queridos também, quis o destino que acabassem juntando-se e enganando-me... A terra lhes seja leve! ( $D C$, p. 210) 
Os indícios são grandes, como a desconfiança de que seu filho, Ezequiel, seja na verdade do falecido Escobar. O autor dá a entender que a primeira a descobrir a semelhança foi sua mãe:

Disse-lhe que começava a achar minha mãe um tanto fria e arredia com ela. Pois aqui mesmo valeu a arte fina de Capitu!

- Já disse a você o que é; cousas de sogra. Mamãezinha tem ciúmes de você; logo que eles passem e as saudades aumentem, ela torna a ser o que era. Em lhe faltando o neto...

- Mas eu tenho notado que já é fria também com Ezequiel. Quando ele vai comigo, mamãe não lhe faz as mesmas graças. ( $D C$, p. 172)

Depois desse capítulo CXV, "Dúvida sobre dúvidas", o início do seguinte, capítulo CXVI, "Filho do homem", nega suas percepções dos modos de sua mãe:

Apalpei José Dias sobre as maneiras novas de minha mãe; ficou espantado. Não havia nada, nem podia haver cousa nenhuma, tanto eram os louvores incessantes que ele ouvia "à bela e virtuosa Capitu" (DC, p. 173)

Mais adiante, no mesmo capítulo, revela-se o motivo do título, "Filho do homem":

Desta vez falou ao modo bíblico (estivera na véspera a folhear o livro de Ezequiel, como soube depois), e perguntava-lhe: "Como vai isso, filho do homem?" "Dize-me, filho do homem, onde estão os teus brinquedos?" "Queres comer doce, filho do homem?"

- Que filho do homem é esse? perguntou Capitu agastada.

- São os modos de dizer da Bíblia.

- Pois eu não gosto deles, replicou ela com aspereza. $(D C$, p. 174)

A ironia do título deve-se ao duplo sentido da expressão "filho do homem", que, no caso, é Escobar. Acrescentam-se a isso os modos ásperos e agastados de Capitu. Um pouco mais adiante, quando José Dias pede que Ezequiel lhe imite o modo de andar, há novo jogo de duplicidade interpretativa:

Eu mesmo achava feio tal sestro. Alguns dos gestos já lhe iam ficando mais repetidos, como o das mãos e pés de Escolbar; ultimamente, até apanhara o modo de voltar da cabeça deste, quando falava, e o de deixá-la cair, quando ria. $(D C$, p. 174)

Recorde-se apenas que, nesse momento da narrativa, Escobar ainda está vivo, o que permite, já que o menino é dado a imitar os outros, que ele macaqueie os gestos do amigo de Bento. Contudo, na ambiguidade montada por meio da narrativa, o autor vai 
preparando o terreno para armazenar indícios que justifiquem sua hipótese de que foi traído. No capítulo CXXXI, “Anterior ao anterior”, o autor indica ao leitor implícito que a própria Capitu já não podia esconder as semelhanças entre o menino e o suposto verdadeiro pai:

- Você já reparou que Ezequiel tem nos olhos uma expressão esquisita? perguntou-me Capitu. Só vi duas pessoas assim, um amigo de papai e o defunto Escobar. Olha, Ezequiel; olha firme, assim, vira para o lado de papai, não precisa revirar os olhos, assim, assim...

$[\ldots]$

Aproximei-me de Ezequiel, achei que Capitu tinha razão; eram os olhos de Escolbar, mas não me pareceram esquisitos por isso. Afinal não haveria mais que meia dúzia de expressões no mundo, e muitas semelhanças se dariam naturalmente. (DC, p. 190)

O mesmo jogo de indeterminação acontece. Enquanto as impressões de Capitu indicam a semelhança, o comentário final do autor fictício mostra que poderiam ser apenas isso, "semelhanças". Mas tudo com muita ambiguidade, porque os olhos não eram estranhos por causa da expressão, o que deixa em aberto novas interpretações, novas hipótese, novas dúvidas, cujo objetivo é convencer o leitor implícito. Por isso, no capítulo seguinte, "O debuxo e o colorido", ele afirma:

\footnotetext{
Nem só os olhos, mas as restantes feições, a cara, o corpo, a pessoa inteira, iam-se apurando com o tempo.

$[\ldots]$

Escobar vinha assim surgindo da sepultura, do seminário e do Flamengo para se sentar comigo à mesa, receber-me na escada, beijar-me no gabinete de manhã, ou pedir-me à noite a bênção do costume. $(D C$, p. 191)
}

Chegamos até aqui para mostrar como o autor fictício, Dom Casmurro, narra as impressões do protagonista de uma traição, Bento Santiago, a partir do conhecimento que possui do futuro da narrativa. A montagem da narração indica os jogos com o passado e o futuro da história que o autor constrói. Por isso, a indicação dos capítulos é importante, para demonstrar como o modo de contar é feito para jogar com o tempo de leitura do leitor empírico. Assim, antes do capítulo CXXXI, há o capítulo intitulado "Um dia...", em que Dom Casmurro descreve seu "andar calado e aborrecido", dizendo que, ao ser inquirido por Capitu, justificou-se afirmando que os "negócios andavam mal" (DC, p. 189). A verdade, porém, é a desconfiança que começa a aflorar de que tenha sido traído e de que seu filho seja de outro. A genialidade do autor é explicitar a montagem do livro ao leitor, por isso termina o capítulo assim: 
...Perdão, mas este capítulo devia ser precedido de outro em que contasse um incidente, ocorrido poucas semanas antes, dous meses depois da partida de Sancha. Vou escrevê-lo; podia antepô-lo a este, antes de mandar o livro ao prelo, mas custa muito alterar o número das páginas; vai assim mesmo, depois a narração seguirá direita até o fim. Demais, é curto. $(D C$, p. 189)

O que o autor confessa como inépcia e preguiça na ordenação do livro revela-se como a arbitrariedade de escolher o modo de apresentar os fatos, o que surge carregado de ironia ao nomear o capítulo seguinte, “Anterior ao anterior". Habilidoso e ardiloso é o autor fictício de Machado de Assis e, ao sê-lo, indetermina, pela própria infidelidade que expõe ao leitor ao mentir-lhe, evidenciando que não é confiável e que, não o sendo, tudo o que narra pode ser mentira. Ao mesmo tempo, as reminiscências são apresentadas como fatos, portanto como inegáveis; mas, por sua vez, são novamente indeterminadas por se tratar de narração em primeira pessoa. Junto a toda essa montagem, a narrativa se temporaliza nos comentários do autor fictício que faz surgir um tempo não da memória, mas da construção do discurso a partir da sua liberdade de autor conhecedor do futuro da história.

Apresentamos essa análise de Dom Casmurro para expormos agora a da construção da narrativa de Grande Sertão: Veredas. A figura do narrador Riobaldo já foi estudada no subcapítulo anterior e ela é semelhante à do autor fíctício de Machado de Assis no aspecto de que ambos são sujeitos da dúvida. Dom Casmurro não sabe se foi traído ou se as semelhanças são apenas ilusões criadas pelo seu ciúme. Já Riobaldo é cindido pelas três dúvidas: a do pacto, a da morte de Diadorim e a de um amor homossexual. Em Dom Casmurro, já demonstramos como a caracterização do autor fictício estrutura a narrativa e que esta, por sua vez, engendra um jogo com os tempos do presente da narração com o passado rememorado e com o futuro como construção da narração. Basta, agora, desenvolver como é montada a narrativa do romance de Guimarães Rosa e como se dá o jogo com os tempos da enunciação e do enunciado.

O primeiro jogo com os tempos é explicitado na seguinte fala de Riobaldo:

De primeiro, eu fazia e mexia, e pensar não pensava. Não possuía os prazos. Vivi puxando difícil de difícel, peixe vivo no moquém: quem mói no asp'ro, não fantasêia. Mas, agora, feita a folga que me vem, e sem pequenos dessossegos, estou de range rede. E me inventei neste gosto, de especular idéia. $(G S: V$, p. 7$)$

Os tempos se dividem, neste trecho, entre os costumes e hábitos do passado, jagunço cachorrando pelo sertão, e os do presente de um narrador que, nas palavras de 
Wilson Martins, é “como um 'intelectual' - o espírito roído de dúvidas e preocupações insolúveis" (MARTINS, 1968, p. XVI). Esses hábitos temporalizam as ações, como mostra Hansen (2000, p. 54):

O discurso do narrador se monta [...] sobre oposições binárias: há um tempo do trabalho e um tempo do não-trabalho ("moer no asp'ro", "puxando difícil de difícel" X "folga", "range rêde"); um tempo da ação e um tempo da contemplação ("fazia e mexia" X "especular idéia"); um tempo da nãodisponibilidade e um tempo da disponibilidade ("pensar não pensava" X "me inventei...") etc.

A sua posição atual de velho e respeitado proprietário de terras, que lê espaçadamente um bom livro, permite que o narrador Riobaldo pense, pois não precisa trabalhar. Isso demonstra também sua posição social, não mais rasa, não mais de trabalhador, mas sim de dono. A divisão dos hábitos e costumes indica, por meio da divisão de temporalidades, a diferença entre o Riobaldo do passado e o do presente. Portanto, no presente ele é um ser diferente daquele do passado. Contraditoriamente, ele quer relembrar aquele ser do passado, mas o seu intuito não é o mesmo de Dom Casmurro. Riobaldo não quer unir as pontas de sua vida, nem recuperar o tempo vivido. O que ele deseja é ultimar o eu dele no passado, por isso sua narração também é construída com o objetivo de conseguir fazê-lo. O jagunço Riobaldo surge pelo discurso do narrador por meio de muita indeterminação. Assim, ele lança ao "doutor": "Jagunço é o sertão. O senhor pergunte: quem foi que foi que foi o jagunço Riobaldo?" (GS: $V, \mathrm{p}$. 284). Ou quando, nas Veredas-Mortas, a propósito do pacto, ele exclama: "Ah - eu, eu, eu! 'Deus ou o Demo - para o jagunço Riobaldo!' A pé firmado.” (GS:V, p. 385). Começado o ritual do pacto, ele mostra sua determinação ("A pé firmado") e deixa a escolha para quem o queira, Deus ou o diabo. Outro exemplo do ser de Riobaldo jagunço é quando ele, já chefe do bando, está jantando na casa de seo Ornelas e pergunta pelo nome de uma menina, que o anfitrião diz ser sua neta. Riobaldo percebe o medo "nos tons do velho Ornelas" (GS:V, p. 417), pois se quisesse poderia matar o velho e usar a neta, mas acontece algo diferente:

Deu silêncio. [...] A mocinha me tentando, com seu parado de águas; a boniteza dela esteve em minhas carnes. Ela perigou. Não perigou: no instante, achei em minha idéia, adiada, uma razão maior - que é o sutil estatuto do homem valente. Aquela formosura, aquela delicadezinha, então podiam mesmo ser assim, em toda segurança, feito ela fosse, por um exemplo, filha minha. ( $G S: V$, p. 417) 
Por esse motivo, desiste de suas más intenções e decide defender a menina, neta do velho, o que o faz afirmar:

\begin{abstract}
A menina-mocinha, que eu agarrava nos braços, era uma quanta-coisa primorosa que se esperneia... Mas eu não quis! Ah, há-de-o, quanto e qual não quis, digo ao senhor: e Deus mesmo baixa a cabeça que sim: ah, era um homem danado diverso, era, eu - aquele jagunço Riobaldo... (GS:V, p. 417) (grifo meu)
\end{abstract}

O uso do demonstrativo de $3^{\mathrm{a}}$. pessoa "aquele" produz a distância existente entre o Riobaldo do presente e o do passado, pelo menos essa é a intenção do narrador ao analisar "aquele jagunço Riobaldo" como um outro. Continuando a se separar daquele jagunço Riobaldo, o narrador afirma novamente a distância em relação a ele quando conta o desejo de matar também reprimido. Na ocasião, também como chefe do bando, Riobaldo recebe um homem chamado nhô Constâncio Alves, que diz ter conhecido o chefe do bando quando este ainda era menino. De repente, após um sussurro do menino Guirigó, Riobaldo deseja matar o homem, mas desiste e diz que isso se deveu ao fato de ter conseguido impedir que o diabo o manobrasse. Neste trecho da história, o narrador novamente comenta o acontecido e separa-se do jagunço Riobaldo: "E é preciso, por aí, o senhor ver: quem é que era e que foi aquele jagunço Riobaldo!” ( $G S: V$, p. 430). Notese, novamente, o uso do demonstrativo "aquele", reforçado agora pelo verbo no pretérito imperfeito ("era") e depois no pretérito perfeito ("foi"), significando ação acabada, ou seja, que o jagunço Riobaldo já não existe mais. Algumas páginas à frente na narrativa e nova separação: "Fui o chefe Urutú-Branco - depois de ser Tatarana e de ter sido o jagunço Riobaldo. Essas coisas larguei, largaram de mim, na remotidão." ( $G S: V$, p. 496). Divide-se o ser de Riobaldo em quatro partes, quatro personagens: o chefe, o Tatarana (atirador), o jagunço Riobaldo e o narrador, que nega os três anteriores. Veja-se que este último separa o atirador do jagunço, sendo que foi essa habilidade que o fez famoso e imprescindível para o bando e merecedor de respeito. A separação parece não durar, pois ela vem com a indeterminação, com a ambiguidade, já que o narrador, em outro trecho, afirma: "Essa, foi a noite que eu dormi: sendo o chefe Urutú-Branco, mesmo dizer - o jagunço Riobaldo...” (GS:V, p. 526). Para terminar, ele ultima o jagunço Riobaldo, logo após a batalha na rua do Paredão:

Resoluto saí de lá, em galope, doidável. Mas, antes, reparti o dinheiro, que tinha, retirei o cinturão-cartucheiras - aí ultimei o jagunço Riobaldo! ( $G S: V$, p. 546) 
Mesmo com a muita ambiguidade, Riobaldo tem a intenção de, durante a narração, desligar-se das figuras do passado, do que ele foi. Assim, onde Dom Casmurro relembra para unir, Riobaldo rememora para separar. O que não impede que ambos fracassem em seus objetivos propostos pelo narrar. Se o primeiro não conseguiu juntar as pontas de sua vida, o segundo não ultima o jagunço. Na verdade, esse fracasso engendra outra forma de tempo, que se espalha por toda a narrativa. Como dissemos, ambos, autor fictício e narrador, conhecem toda a história, mas as maneiras de lidar com esse conhecimento são distintas. Dom Casmurro joga com o tempo como um autor, por isso organiza sua narração em forma de capítulos, pois escreve e justifica a falta de vontade em alterar a ordem de um capítulo pelo outro por causa do trabalho que daria mudar o número de páginas. O pseudoautor machadiano explicita a sua arbitrariedade como autor que conduz a história. O narrador rosiano, por outro lado, é constituído como um orador, como um falante, como um aedo sertanejo. Verossimilmente, o texto, como mimese ou imitação da armação da oralidade, não se organiza em capítulos, mas é um bloco único e compacto de fala:

\begin{abstract}
Empregando elementos da variedade regional e da narrativa oral, Grande Sertão: Veredas é um discurso escrito para ser lido como se estivesse sendo ouvido. Não está dividido em capítulo e a única informação sobre o conteúdo referencial aparece no título e numa epígrafe de origem popular ( $O$ diabo na rua no meio de redemoinho) que repetida várias vezes, funciona como um abstrato e sugere de alguma forma a natureza do romance. (WARD, 1984, p. 80)
\end{abstract}

Por esse motivo, por ser mimese de fala ou construção discursiva baseada na oralidade com o objetivo de ser lida e, consequentemente, ouvida, sua estrutura é outra e, portanto, também é outra a temporalidade resultante dela. Com essa montagem, Guimarães Rosa consegue efeitos de tempo diferentes dos conseguidos por Machado de Assis. Para apresentá-los, analisaremos um trecho longo do Grande Sertão: Veredas, com o fim de expor a montagem da cena, que no exemplo que examinaremos lida com o recuperar do passado pelo presente e questiona dois futuros, a saber, o do destino e o da narração. O primeiro permanece insondável e vale como possibilidade de alterar o que o narrador já conhece, ou seja, sua vida, mas de que o leitor ainda não tem ciência porque não leu.

Assumindo o comando do bando, o jagunço Riobaldo, atirador Tatarana, tornase o chefe Urutú-Branco, cuja afirmação se dá com os crimes cometidos, sendo que o primeiro é o ataque à fazenda do Hermógenes, desbravando o Liso do Sussuarão, raso 
que Medeiro Vaz não foi capaz de enfrentar. Vencendo a força do imaginário popular que afirma que o lugar é intransponível, pois nesse momento, chefe, conta com o poder do suposto pacto, Riobaldo queima a casa do Hermógenes e rapta sua esposa, sendo que, mesmo sem resistência por parte dos que defendiam a fazenda, "o mal regeu" "o que se matou e estragou - de gente humana e bichos, até boi manso que lambia orvalhos, até porco magro em beira de chiqueiro" (GS:V, p. 470). Pondo em prática seu poder, "meus exércitos" (idem), o Urutú-Branco se afirma: "Virei os tigres; mas mesmo virei sendo o Urutú-Branco, por demais" (GS:V, p. 471). Após o rapto, o bando segue sob a chefia inegável de Riobaldo e, logo em seguida, encontram um velho, a quem "o catrumano Teofrásio com sua garrucha antiquíssima apontou, era um velho. Desse, eu digo, salvei a vida" (GS:V, p. 473). O velho, que tinha um dos pés pela metade por causa de picada de cobra e que era "quase-dôido, que falava no tempo do Bom Imperador" (idem) - marcação temporal de um tempo antigo, desde a arma do catrumano até o assunto do velho - , idolatra Riobaldo por ter-lhe salvo a vida. Por isso, esse velho, entre elogios ao "Chefão cangaceiro" (GS:V, p. 474), tenta recompensar o chefe dando-lhe a localização de um tesouro:

\footnotetext{
Acabando que, para me render benefício de agradecimento, ele me indicou, muito conselhante, que, num certo resto de tapera, de fazenda, sabia seguro de um dinheirão enterrado fundo, quantia desproposital. Eu fosse lá... - ele disse - ; eu escavasse tal fortuna, que merecida, para meus companheiros e para $\operatorname{mim} . . .(G S: V$, p. 474)
}

Riobaldo não acredita, mas pergunta onde é o lugar, que era o Riacho-dasAlmas. O jogo do tempo surge do presente, a partir do comentário do narrador, porque, para se chegar ao local indicado pelo velho, o chefe deveria passar "pelo São Josezinho da Serra, onde assistia Nhorinhá, lugarejo ditoso." (GS:V, p. 475). Sabendo isso, Riobaldo comenta:

\footnotetext{
Segunda vez com Nhorinhá, sabível sei, então minha vida virava por entre outros morros, seguindo para diverso desemboque. Sinto que sei. Eu havia de me casar feliz com Nhorinhá, como o belo do azul; vir aquém-de. Maiores vezes, ainda fico pensando. Em certo momento, se o caminho demudasse o que aconteceu não tivesse acontecido? Como havia de ter sido a ser? (GS:V, p. 475-6) (grifo meu)
}

A temporalidade está relacionada ao pressuposto de que o narrador conhece o futuro da narrativa; assim, ele sabe das mortes da batalha do Paredão e da morte 
principal, a de Diadorim. Assim, lidando com o conhecimento prévio que o interlocutor não tem, ele questiona a possibilidade de alterar o futuro, que age como destino ou como providência divina. Ao mesmo tempo se debate com o livre arbítrio de Riobaldo, detentor da chefia e, portanto, responsável por comandar a vida de seus jagunços. Assim, o jogo com os tempos é constatado a partir dos tempos verbais que remetem às possibilidades de alteração dos fatos, mas só sondáveis a partir do momento em que já estiverem acabados. Por isso, a lamentação:

Mas - se eu tivesse permanecido no São Josezinho, e deixado por feliz a chefia em que eu era o Urutú-Branco, quantas coisas terríveis o vento-dasnúvens havia de desmanchar, para não sucederem? (GS:V, p. 476)

Riobaldo lida com a questão do destino, que se resume em: "Possível o que é — possível o que foi." (GS:V, p. 476). Com essa expressão, o narrador demonstra que poderia alterar os fatos da história, já que é "possível o que é", ou seja, o que eu conto, já que ao contar manipulo os fatos passados pela memória, que se resume assim: "O passado - é ossos em redor de ninho de coruja..." (GS:V, p. 476). Em outras palavras, o passado é resto de restos, sobras do que foi e que é reconstruído a partir do tempo da memória. Contudo, a reconstituição do passado, influenciada pelos sentimentos do presente, pressupõe um recorte e uma seleção de alguns fatos em relação a outros. Assim, quando Riobaldo explicita sua técnica, expõe também o jogo com os tempos que tem sua base no presente da enunciação:

\footnotetext{
A lembrança da vida da gente se guarda em trechos diversos, nem não misturam. Contar seguido, alinhavado, só mesmo sendo as coisas de rasa importância. De cada vivimento que eu real tive, de alegria forte ou pesar, cada vez daquela hoje vejo que eu era como se fosse diferente pessoa. Sucedido desgovernado. Assim eu acho, assim é que eu conto. O senhor é bondoso de me ouvir. Tem horas antigas que ficaram muito mais perto da gente do que outras, de recente data. O senhor mesmo sabe. $(G S: V$, p. 89)
}

Acrescenta-se ao trecho acima a seguinte fala, continuação das reflexões de Riobaldo sobre o tempo do que poderia ter sido e que não foi: " $\mathrm{E}-$ mesmo - possível o que não foi." (GS:V, p. 476). O tempo da memória, organizador primário da estrutura da narrativa, é manipulado para que se possa temporalizar o contar de Riobaldo. É técnica habilidosa de Guimarães Rosa. Por isso, Benedito Nunes relaciona o problema do tempo com o ethos do narrador, como já definido, e com o ato de narrar: 
Segundo entendemos, essa filosofia, instância de questionamento, chamada a servir-nos de guia, abre-se, em Grande sertão: veredas, em torno do problema do tempo, porquanto é justamente o tempo aquele horizonte de confluência da realidade problemática, que o tratamento do mito sobredeterminado por um ethos permitiu entrever, com a função, também problemática, do ato de narrar, diretamente visada pelo narrador, e intrínseca ao desenvolvimento do romance. (NUNES, 1983, p. 202)

Assim, o narrador, fonte de todo o discurso e, portanto, de sua montagem, temporaliza a sua existência e a de todos os outros quando narra. A narração é a própria instância temporal do presente, que, como visto com Benveniste, é a inserção do ser no mundo, do ser no agora da enunciação. O que acontece em Grande Sertão: Veredas é que o narrador se debate angustiado pela culpa que é decorrência de seus atos no passado. Ao tentar mudar o que fez, reescreve o passado, sendo que não podemos determinar se o que foi é o que é narrado. A esse respeito, Garbuglio analisa o ato de narrar como problemática do narrador, separando, assim, a questão da recepção:

\footnotetext{
Houve um fato e, depois sua reconstrução e a seguir a decomposição. Mas a palavra que recupera e cristaliza o acontecimento, tornando-o presente teria sido fiel à memória e a memória aos acontecimentos? Quer dizer, aquilo que o narrador quis traduzir é o que está na palavra ou seria outra coisa? Se esta desconfiança com o poder do signo linguístico perturba o narrador que sabe das dificuldades do trato com ele, não pode perturbar, da mesma forma, o leitor porque, para nós, o que se quer dizer, é somente aquilo que está na palavra, não é o que se pretendeu, mas o que se conseguiu que a palavra traduzisse. (GARBUGLIO, 2005, p. 27)
}

Exemplar a análise para nosso estudo, pois estabelece uma distinção entre o que está dito e o que poderia ser dito, problema que cabe ao narrador. A esse jogo com o signo, acrescentam-se as possibilidades de significação do tesouro, referido no trecho citado acima pelo velho manco, pois, ao contar esse fato (que faz parte de suas peripécias e pertence ao épos) e questionar o interlocutor (que está no presente de enunciação do discurso e faz parte do drama), o narrador faz com que os dois gêneros se cruzem. Como conhece o futuro, produz ambiguidade quando faz o tesouro, mencionado pelo velho, referir-se no sentido denotativo a dinheiro, e, no conotativo, ao amor que sente por Nhorinhá e à possibilidade de ter salvado seu outro amor, Diadorim. A reflexão do narrador traz o épos para a cena do drama, na qual fantasia um novo presente, reconstruindo o passado. Mas ele sabe que não é possível e faz questão de lembrar ao interlocutor que não o entenda errado, porque, apesar de desejar isso, confirma o amor que sente por sua esposa Otacília, trazendo à tona um fato que faz 
parte do presente. Comentando o narrado, Riobaldo reflete sobre o poder que suas ações tiveram e, com isso, o peso de suas culpas aumenta.

As culpas de Riobaldo temporalizam a narração, fazendo com ele deseje alterar o que foi. Isso acontece a partir do momento em que as ações giram em torno dele, ou seja, depois da morte do grande chefe Joca Ramiro, que foi consequência do fato capital do livro, a absolvição de Zé Bebelo no julgamento na fazenda Sempre Verde. Com esse fato, divisor da constituição da narrativa e, portanto, da maneira de lidar com o tempo, tem início a ascensão de Riobaldo até chegar à chefia. Por esse motivo, a partir da Guararavacã do Guaicuí, os fatos da história estão subordinados à figura de Riobaldo, que se torna o centro da narrativa. É por isso que Garbuglio separa a história do Grande Sertão em duas partes:

Parece-me clara a existência, no plano objetivo, de dois momentos distintos e em sucessão, separados pelo "episódio" do julgamento. Ainda mais, esse segundo momento se realiza na presença de duas sublinhas que articulam para continuar o processo narrativo. (GARBUGLIO, 2005, p. 25)

Essas duas sublinhas nos levam a dois modos de organização da narrativa que engendram temporalidades distintas. A primeira é a que se dá até o episódio do "julgamento" em que Riobaldo observa as coisas acontecerem e as comenta, crítico, produzindo uma narração em vai e vem. A segunda desestrutura esse tipo de narrativa e ele passa a ser o centro e, com isso, os comentários se voltam para as suas ações e as consequências delas. Essa segunda já foi iniciada acima e, para finalizá-la, basta concluirmos com as consequências temporais que ela impõe. A principal é que, como dissemos, Riobaldo, narrador no presente e conhecedor da história, manipula a narração, porque conhece o futuro. Seu objetivo é relembrar para separar, ou seja, ele deseja, a partir da fala, reconstruir outro Riobaldo, expurgar aqueles seus outros seres das culpas que o próprio narrador atribui a eles. Por isso, a constante tentativa, já mostrada, de ultimar o jagunço Riobaldo, o atirador Tatarana e, principalmente, o chefe UrutúBranco, responsável por tantas mortes, entre elas a de Diadorim. No final da linha está o presente e Riobaldo sabe que ele é fruto de todos os outros, mas não quer que isso seja. Para tanto, lida com o tempo, pois projeta um futuro, como expectativa, que não o anima, já que a possível consequência é o inferno cristão.

Narrando todos os outros Riobaldos, o narrador tenta reconstruí-los, mas fracassa, o que se observa nas constantes indeterminações que sua fala enuncia como 
nonsense e paradoxo, pois afirma que existiu e existe um jagunço Riobaldo na fórmula que exclui a lógica aristotélica, isso é, "fui e não fui”" (GS:V, p. 197). Esse jogo temporaliza os diversos Riobaldos e as negações e afirmações simultâneas fazem com que ele seja sempre outro, toda vez que é enunciado. Com isso, os diversos Riobaldos tornam-se topoi (figuras históricas) - como observamos na teoria do tempo de Koselleck no primeiro capítulo deste estudo. Um exemplo semelhante é a personagem Jó Joaquim do conto "Desenredo" de Tutaméia. Nele, o protagonista, após conseguir casar-se com sua amada, é traído. Depois de um período de reclusão, ele começa a recontar o passado e cria uma nova mulher que já não é culpada como a primeira, mas limpa e pura:

Nunca tivera ela amantes! Não um. Não dois. Disse-se e dizia isso Jó Joaquim. Reportava a lenda a embustes, falsas lérias, escabrosas. Cumprialhe descaluniá-la, obrigava-se por tudo. Trouxe à boca-de-cena do mundo, de caso raso, o que fora tão claro como água suja. Demonstrando-o, amatemático, contrário ao público pensamento e à lógica, desde que Aristóteles a fundou. O que não era tão fácil como refritar almôndegas. Sem malícia, com paciência, sem insistência, principalmente. (ROSA, 2001, p. 74)

O processo, contudo, depende de que ele mesmo acredite no que conta, por isso: “Todos acreditavam. Jó Joaquim primeiro que todos.” (idem, p. 75). Assim, Jó Joaquim reconta a história, operando com o tempo do passado a partir do presente:

O ponto está em que o soube, de tal arte: por antipesquisas, acronologia miúda, conversinhas escudadas, remendados testemunhos. Jó Joaquim, genial, operava o passado - plástico e contraditório rascunho. Criava nova, transformada realidade, mais alta. Mais certa? (ROSA, 2001, p. 74)

Negando a lógica binária de $\mathrm{V} / \mathrm{F}$ que implica o terceiro excluído, é possível escapar aos padrões e reescrever o que aconteceu, produzindo o que poderia ter acontecido. Como disse Garbuglio, o que interessa é o que se conseguiu transmitir por meio do signo linguístico, ou, como quer o narrador do conto, "E pôs-se a fábula em ata” (ROSA, 2001, p. 75). A maneira sutil de demonstrar isso aparece nos três possíveis nomes da amada no início do conto, a saber, Livíria, Rivília ou Irlívia. Cada qual corresponde aos três amores vividos por ela na primeira parte do conto. No final, limpa e pura dos pecados cometidos, ela passa a ser chamada de Vilíria.

O conto é exemplar para nossa análise, mas se nele o protagonista consegue mudar o passado a partir do presente reconstruindo um novo futuro, no Grande Sertão: 
Veredas o que se nota é o fracasso do narrador. Esse não consegue negar seus outros eus do enunciado, sendo que acontece o oposto: a cada vez que os enuncia, produz novas formas deles, negando as que havia afirmado anteriormente. Isso gera um constante devir dele mesmo, que sempre quer se confirmar outro. Teria, portanto, um devir outro do eu que é ele mesmo. Em termos de temporalidade, é um passado retomado pelo presente do narrador, que o deseja reconstruir para que os fatos não tenham acontecido, o que gera seres que poderiam ter sido, mas que não foram e que a narrativa vai tornando outros como expectativas, isso é, futuro. É um redemoinho de tempo entre passado e futuro que se originam do presente da enunciação. No centro de tudo está a fala inepta, que engendra uma narrativa sábia, elaboradíssima.

O exposto acima, junto com o jogo dos tempos, acontece na segunda parte do romance, em que Riobaldo é o centro. Na primeira, a manipulação se dá a partir de fora, ou seja, Riobaldo não é mais núcleo, mas quase um observador que narra a importância das ações dos grandes chefes e os grandes acontecimentos. Isso se dá em blocos que não seguem a ordem cronológica, principalmente por não haver um centro que os defina. Assim, a narração caminha em vai e vem e os comentários sobre as dificuldades de organizá-los são frequentes. Impõe-se o tempo da memória e com ele o do comentário, fazendo com que as ações sejam interrompidas a todo momento para que se retirem as conclusões de cada caso. Por ter essa forma de narrativa, que num primeiro momento parece "confusa", "desorganizada", é que o primeiro contato com o livro afasta o leitor que procura o romance tradicional, com enredo cronológico ou pelos menos organizado linearmente pelo narrador, como constata Garbuglio: À pergunta, você já leu Grande Sertão: Veredas, o comum é ouvir-se a
resposta: "Li umas trinta ou quarenta páginas, mas não consegui entender
nada. Além de "chato", não tem história, a gente fica perdido". Na verdade,
não é possível compreender-se o romance pelas suas primeiras páginas, à
vista de sua aparente desordem e, principalmente, pela falta de pontos de
apoio. E se o leitor procura o enredo, a história caracterizadora do romance
tradicional, então, sua desorganização é fato natural e inevitável.
(GARBUGLIO, 2005, p. 10)

Os "pontos de apoio" do leitor - ou, nas palavras de Iser, o horizonte de expectativa prévio ou o que o leitor espera encontrar na leitura do romance - são frustrados logo no início. Como exemplo, vejamos o seguinte trecho:

Viver é muito perigoso... Querer o bem com demais força, de incerto jeito, pode já estar sendo se querendo o mal, por principiar. Esses homens! Todos 
puxavam o mundo para si, para o concertar consertado. Mas cada um só vê e entende as coisas dum seu modo. (GS:V, p. 13)

O narrador está analisando as ações dos chefes que conheceu. Começa expondo ao interlocutor uma filosofia paradoxal, ou seja, a de que, ao desejar demais o bem, acaba-se praticando o mal. Depois disso, relata certos "homens" que atraiam o mundo para si, ou seja, que eram o centro, o núcleo das decisões. O mundo é o sertão e o sertão é o mundo, como se saberá durante a narrativa. Também se saberá (o leitor que continuar a ler o livro) quem são esses homens que querem consertar o mundo, representado aqui pelo reger da orquestra ("concertar"). Contudo, o narrador já tem suas conclusões e a principal delas, como afirma logo no começo do trecho, é filosófica. Ela afirma a visão em perspectiva: cada qual enxerga as formas de consertar do seu modo. Em seguida, o narrador dá nomes e informações curtas sobre cada um desses "homens":

Montante, o mais supro, mais sério - foi Medeiro Vaz. Que um homem antigo... Seu Joãozinho Bem-Bem, o mais bravo de todos, ninguém nunca pôde decifrar como ele por dentro consistia. Joca Ramiro- grande homem príncipe! - era político. Zé-Bebelo quis ser político, mas teve e não teve sorte: raposa que demorou. Sô Candelário se endiabrou, por pensar que estava com doença má. Titão Passos era o pelo prêço de amigos: só por via deles, de suas mesmas amizades, foi que tão alto se ajagunçou. Antônio Dó - severo bandido. Mas por metade; grande maior metade que seja. Andalécio, no fundo, um homem-de-bem, estouvado raivoso em sua toda justiça. Ricardão, mesmo, queria era ser rico em paz: para isso guerreava. Só o Hermógenes foi que nasceu formado tigre, e assassim. E o "UrutúBranco"? Ah, não me fale. Ah, esse... tristonho levado, que foi - que era um pobre menino do destino... (GS:V, p. 13-4)

Desses nomes todos, alguns participam diretamente da história, como Medeiro Vaz, Joca Ramiro, Zé Bebelo, Sô Candelário, Titão Passos e Urutú-Branco, que foram chefes, cada qual durante um determinado tempo, do bando de jagunços. O leitor não sabe, não há referência alguma, mas Antônio Dó e Andalécio só aparecem num causo contado nas páginas 151e 152. Já Joãozinho Bem-Bem é o jagunço exemplar e modelo de Zé Bebelo, além de ser aquele da regra de ferro: "Mas Diadorim dava como exemplo a regra de ferro de Joãozinho Bem-Bem - o sempre sem mulher, mas valente em qualquer praça." (GS:V, p. 174). O outro, Hermógenes, é a personificação do mal, o pactário, o único da história essencialmente mau. Repare-se também no interlocutor, “doutor", leitor implícito, já analisado, que aqui fica distante do leitor empírico, porque ele aparentemente conhece fatos da história, tanto que é ele quem implicitamente, por meio da fala do narrador, pergunta pelo "Urutú-Branco". Notem-se as aspas que 
caracterizam o discurso de outro. Esse Urutú-Branco, o leitor descobrirá, na página 401, que é o próprio narrador quando, ao assumir a chefia do bando, depondo Zé Bebelo, recebeu deste o apelido. Escolhemos esse trecho para demonstrar como o narrador manipula a narrativa e adianta fatos e personagens da história. Aqui, é importante a presença do leitor implícito, representado pelo “doutor" ou "senhor", que ouve a história do narrador. Ele é essencial pelo fato de a história ser conduzida pressupondo na recepção. Como vimos, os autores fictícios de Machado de Assis também constroem seus interlocutores, leitores implícitos. Contudo, o tratamento dado a eles é muito distinto em ambos. Por exemplo, em Dom Casmurro, o autor assim se dirige à leitora, num capítulo dedicado a ela, chamado "Não faça isso, querida!":

A leitora, que é minha amiga e abriu este livro com o fim de descansar da cavatina de ontem para a valsa de hoje, quer fechá-lo às pressas, ao ver que beiramos um abismo. Não faça isso, querida: eu mudo de rumo. ( $D C$, p. 179)

O comentário é decorre da insinuação de que Sancha, a mulher de seu melhor amigo, Escobar, estava interessada nele, Bento Santiago. Como já dissemos, a técnica serve para expor o arbitrário da escolha do que se irá narrar. O caso fica mais explícito em Memórias Póstumas, porque, se Dom Casmurro atrai seu leitor para o texto, o autor defunto o afasta no capítulo chamado "O senão do livro", que analisamos no final do primeiro capítulo deste estudo, no qual o autor fíctício declara que "o maior defeito deste livro és tu, leitor" (MP, p. 112). Caracterizado pela ironia, o defunto autor explicita todo o seu modo de narrar, como é observável no capítulo IX, "Transição":

E vejam agora com que destreza, com que arte faço eu a maior transição deste livro. Vejam: o meu delírio começou em presença e Virgília; Vírgilia foi o meu grão pecado da juventude; não há juventude sem meninice; meninice supõe nascimento; e eis aqui como chegamos nós, sem esforço, ao dia 20 de outubro de 1805, em que nasci. Viram? Nenhuma juntura aparente, nada que divirta a atenção pausada do leitor: nada. De modo que o livro fica assim com todas as vantagens do método, sem a rigidez do método. (MP, p. 18)

O que diferencia os dois autores machadiano é que Dom Casmurro não ataca seu leitor e não afirma ser bom escritor; já Brás Cubas, além de vangloriar-se da habilidade de suas técnicas narrativas, também zomba do leitor implícito. O que os aproxima, no entanto, é que ambos explicitam suas técnicas. O narrador rosiano não explicita suas técnicas narrativas, ao contrário, o que reina é a sutileza. Assim, quando afirma que não 
consegue contar direito, aproxima-se do leitor implícito. O narrador do Grande Sertão deseja atrair seu interlocutor, quer que ele permaneça em sua fazenda. A narração para ele é essencial. Não há juízo de valor ao compararmos os dois escritores que, junto com Clarice Lispector, são os grandes, em prosa, na Literatura Brasileira. O que se pretende é mostrar a maneira de construir os leitores implícitos e a narração. No romance do autor mineiro, as transições da primeira parte são feitas como correções e desculpas do mal contar do narrador. Assim, ele diz: "Ou conto mal? Reconto"; “Aí, narro. O senhor me releve e suponha"; "Contar é muito, muito dificultoso"; "Falo por palavras tortas". A essas justificativas, surgem os blocos de narrativas, como analisados por Hansen:

\begin{abstract}
A enunciação, tempo da narração, ordena-se por justaposição de blocos, em que o contar de um pedaço $a$ é suspenso para contar-se uma estória $b$ contemporânea, suspensa para se narrar um ditado $c$ simultâneo: o efeito é de alternância narrativa que dissolve o modelo causal-linear do romance, pois em $b$, por exemplo, espera-se o término de $a$ e, quando em $c$, este é assombrado por $a$ que, retornando, liga-se à continuação de $d$ ou $z$, num redemoinho de falas como predicação pura e enunciação fática, em que o contar domina o contado. (HANSEN, 2000, p. 189-90)
\end{abstract}

Nosso objetivo foi mostrar que essa forma de narração entrecruzada por causos, comentários, ditados, ou seja, blocos narrativos, que se unem à história principal, constitui a mesma temporalidade já observada na segunda parte do romance, em que o narrador faz os tempos do passado (enunciado, rememoração, memória) e do futuro (expectativa, seja da leitura, seja do futuro do narrador) sejam misturados num redemoinho de vai e vem dos seres de Riobaldo, sempre anulando, por indeterminações, paradoxos e nonsense, a afirmação anterior. No contar em blocos que se intercruzam e que não necessariamente continuam o que foi relatado no anterior, produzem o mesmo tipo de temporalidade em redemoinho, causando a estranheza e a perturbação do leitor empírico no primeiro contato com o livro.

Isso serve para demonstrar que a arquitetura da narrativa é um reflexo da constituição do narrador. Assim, existem diversas formas de temporalidades no sertão rosiano e aqui pretendemos demonstrar algumas. 


\section{CONCLUSÃo}

Esta dissertação sobre o tempo em Grande Sertão: Veredas começou por apresentar algumas teorias sobre a temporalidade que envolvem diversas questões filosóficas, históricas e artísticas. Após a apresentação delas, a dissertação tentou filtrar algumas teorizações sobre o tempo na obra literária, recorrendo a obras de Benedito Nunes e Mendilow como autores principais. Como exemplificação do que argumentou, tratou da constituição do autor fictício na obra Memórias Póstumas de Brás Cubas e do modo como a escritura dela se ordena, já que, sendo o autor fictício Brás Cubas um autor póstumo, escreve em capítulos para facilitar a vida do leitor. De posse de alguns recursos técnicos usados por Machado de Assis, observou-se como Guimarães Rosa os estiliza, para produzir um narrador falante, Riobaldo, que engendra as temporalidades de sua enunciação como mimese de sua conversa com um "doutor" emudecido. O discurso é, aqui, uma escrita que mimetiza a fala, constituindo o destinatário e o leitor como ouvintes de um romance sem capítulos, montado como um bloco único pelos diversos outros blocos de um todo intotalizável.

Supondo-se a relação de fala e escrita, foi preciso evidenciar a importância da palavra e de sua capacidade de expressão quando desvinculada do que limita, como lógica cartesiana e gramática normativa, suas significações possíveis e inesperadas. Amante de línguas e dicionários, o autor Rosa afirma ser necessário reinventar as linguagens literárias para traduzir suas histórias em "seu idioma". Para escrever incluindo na escrita o que lhe era próximo - Minas Gerais, Cordisburgo, conversas de vaqueiros, histórias da carochinha - tinha de enfrentar a herança dos chamados regionalistas e também dar conta do que fizeram os modernistas brasileiros. O resultado é o estilo singular e inimitável que os inclui e supera.

As veredas de Grande Sertão: Veredas são lugares de perdição, mas a dissertação fez a aposta de que talvez pudessem salvar os que se destorneiam tentando descobrir coisas nas entrelinhas delas, observando os procedimentos retóricos utilizados por Rosa para desdobrar as significações do tempo. Por exemplo, a animização de elementos da natureza, como o vento, que anuncia os acontecimentos futuros para os capazes de entender seus sinais, evidencia que no sertão de Rosa os homens ainda não comeram da fruta do bem e do mal, como que vivendo antes da Revolução Francesa e 
do Iluminismo: conversam com os buritis, os animais falam, há um riachinho que diz coisas ao narrador. Não à toa, o velho Riobaldo é barranqueiro do São Francisco, pois os rios são formas de tempo alusivas da eternidade. O rio Urucúia representa "paz das águas" e simboliza o tempo das pausas e da calma fora da guerra. Mais que ele, o buriti é símbolo da eternidade da paz e do amor; quando comparece, nada o corrompe, sendo o único personagem a sair ileso de toda a narração. Mas o tempo também é como uma divindade terrível, que controla a vida dos homens do sertão como o Destino, que o narrador observa ambiguamente de um depois, o presente da sua fala, a partir do qual constrói as relações que complicam e explicam as tramas passadas como veredas do grande sertão da existência. O tempo não é algo que se possa ignorar, enfim, mas é respeitado, principalmente o futuro do que está além e causa medo e angústia no narrador culpado.

As culpas do narrador constituem sua figura e seu modo de organizar a história. São três: ter feito o pacto com o Diabo; ser o responsável pela morte da pessoa amada; ter amado um homem. Elas são determinantes na ordenação temporal da narrativa, pois a reconstituição do passado é sempre deformada pelo desejo presente do narrador de não ter sido o que foi. Sempre que surgem as falhas do jagunço Riobaldo, o narrador Riobaldo as nega. No caso, sua enunciação feita por paradoxos e a indeterminação do sentido que resulta deles são fundamentais na invenção da obra, porque negam a lógica binária que opõe verdadeiro e falso nos textos regionalistas realistas. No sertão de Rosa, não existe a oposição verdadeiro ou falso, pois verdadeiro $e$ falso são simultâneos, como fluxo temporal de ser e não-ser misturados. O jogo temporal constitui presente, passado e futuro como um redemoinho onde Riobaldo é e não é o jagunço Riobaldo. Com isso, o que está expresso em sua própria configuração de narrador como sujeito da dúvida gerada pelas culpas espelha-se na organização da narrativa, que se faz nos vai- e- vem do fluxo temporal misturado e possível porque o narrador está, como diz, “depois das tempestades" (GS:V, p. 542). Também por isso a história é feita de blocos que, no final, constituem um só, como a totalidade da fala intotalizável de um ex-jagunço e suposto pactário. Como o narrador apresenta diversos níveis cruzados de história, é preciso dar acabamento a todos eles para pôr fim à história do enunciado e à história da enunciação e ele assim o faz:

"Aqui a estória se acabou", diz, significando a estória das andanças épicas (epos) do jagunço Riobaldo. "Aqui, a estória acabada”, diz, significando que ainda há mais a contar, como a devolução dos catrumanos que sobreviveram à luta no Paredão e do 
menino Guirigó e do cego Borromeu a suas terras de origem. Assim, também faltaria falar da certidão de nascimento de Maria Deodorina da Fé Bettancourt Marins. E também dizer que a conversa que se ouviu até o momento já foi feita duas outras vezes. E, para acabar sem terminar, como o narrador diz: "Aqui a estória acaba" (GS:V, p. 546). Afinal, como diz Riobaldo, "pão ou pães, é questão de opiniães” (GS:V, p. 5). 


\section{BIBLIOGRAFIA}

AFRÂNIO, Coutinho. "O modernismo na ficção". In: A literatura no Brasil. $3^{\mathrm{a}}$ Ed. Rio de Janeiro: José Olympio; Niterói: UFF - Universidade Federal Fluminense, 1986, p. $263-590$.

AGOSTINHO, Santo, Bispo de Hipona. Confissões. Trad. Maria Luiza Jardim Amarante. São Paulo: Paulus, 1997, 450p.

ASSIS, Machado de Assis. Memórias póstumas de Brás Cubas. São Paulo: Globo, 1997, 208p.

ASSIS, Machado de Assis. Dom Casmurro. São Paulo: Circulo do Livro, 1991, 219p.

ATAÍDE, Tristão de. "O transrealismo em G. R.". In: COUTINHO, Eduardo F. Coleção fortuna crítica: Guimarães Rosa. Rio de Janeiro: Civilização brasileira, 1991.

BAKHTIN, Mikhail (Volochinov). Marxismo e filosofia da linguagem. Trad. Michel Lahud Yara Frateschi Vieria. São Paulo: Ed. Hucitec Annablume, 2002, 203p.

BENVENISTE, Émile. "O aparelho formal da enunciação". In: Problemas de lingüistica geral II. Trad. Eduardo Guimarães ... |et. al.|. Campinas, SP: Ed. Fontes, 1989, p. 68-90.

BOLLE, Willi. grandesertão.br: o romance de formação do Brasil. São Paulo: Duas Cidades; Ed. 34, 2004, 478p.

BOSI, Alfredo. História concisa da Literatura Brasileira. São Paulo: Ed. Cultrix, 2001, $528 \mathrm{p}$.

BOUTANG, Pierre. O tempo: ensaio sobre a origem. Tradução de Maria Helena Kühner. Rio de Janeiro: DIFEL, 2000, 126p.

CANDIDO, Antonio. "Literatura e Cultura de 1900 a 1945". In: Literatura e sociedade: estudos de teoria e história literária. São Paulo: T. A. Queiroz, 2000, p. $109-$ 138.

CANDIDO, Antonio. "O homem dos avessos". In: Tese e antitese. Ed. Cia Editora Nacional. São Paulo, 1964, p. 119 - 139.

CARPEAUX, Otto Maria. História da Literatura Ocidental. Vol. II. Ed. Alhambra, Rio de Janeiro: 1978.

CODOÑER, Carmen. "El diálogo". in: Géneros literarios romanos: aproximación a su estudio. (org. Dulce Stefanía e Andrés Pociña). Madrid: Ediciones Clásicas Madrid; Universdiade de Santiago de Compostela, p. 69-89. 
COELHO, Nelly Novaes. "A arte narrativa e o espírito lúdico de Guimarães Rosa". In: Suplemento de $O$ Estado de São Paulo, 14/IV/74.

COUTINHO, Afrânio. "Guimarães Rosa". In: COUTINHO, Afrânio. A Literatura no Brasil (volume V, Parte II): Era Modernista. Rio de Janeiro: José Olympio; Universidade Federal Fluminense, 1986, p.475-526.

DANTAS, Paulo. Sagarana emotiva: cartas de J. Guimarães Rosa. São Paulo: Ed. Duas Cidades, 1975.

DANIEL, Mary L. João Guimarães Rosa: travessia literária. Rio de Janeiro: Ed. Livraria José Olympio, 1968, 186p.

EAGLETON, Terry. Teoria da Literatura: uma introdução. São Paulo: Ed. Martins Fontes, 2006.

FERREIRA, Aurélio Buarque de Holanda. Novo Aurélio século XXI. Rio de Janeiro: Nova Fronteira, 1999.

FOUCAULT, Michel. Microfisica do poder. Org. e trad. de Roberto Machado. Rio de Janeiro: Edições Graal, 2003.

GALVÃO, W. N. As formas do falso. Ed. Perspectiva, São Paulo, 1972.

GALVÃO, Walnice Nogueira. A Donzela-Guerreira: um Estudo de Gênero. São Paulo: Ed. Senac, 1998.

GARBUGLIO, José Carlos. Rosa em dois tempos. São Paulo: Ed. Nankin, 2005, 182p.

GUANDALIGNI, Bernardeth Oliver. O exórdio dos diálogos de Cícero. Dissertação de Mestrado, Usp, 2005, 284p.

GUIMARÃES, Hélio de Seixas. Os leitores de Machado de Assis: o romance machadiano e o público de literatura no século 19. São Paulo: Nankin Editorial : Editora da Universidade de São Paulo, 2004, 510p.

HANSEN, João Adolfo. Alegoria: construção e interpretação da metáfora. São Paulo: Hedra, 1987.

HANSEN, João Adolfo. "Introdução: Notas sobre o Gênero Épico". In: Épicos: Prosopopéia: O Uraguai: Caramuru: Vila Rica: A Confederação dos Tamoios: I-Juca-Pirama. Org. Ivan Teixeira. São Paulo: Editora da Universidade de São Paulo: Imprensa Oficial do Estado de São Paulo, 2008.

HANSEN, João Adolfo. "Forma, indeterminação e funcionalidade das imagens de Guimarães Rosa". in: Veredas no sertão rosiano. (org. Antonio Carlos Secchin ... [et al.]. Rio de Janeiro: Ed. 7Letras, 2007, p. 29-49.

HANSEN, João Adolfo. o O: A ficção da literatura em Grande Sertão: Veredas. São Paulo: Hedra, 2000.

HOBSBAWM, Erich J. Bandidos. Rio de Janeiro: Ed. Forense-Universitária, 1975. 
HOISEL, Evelina de C. de Sá. "Elementos dramáticos da estrutura de Grande Sertão: Veredas". In: COUTINHO, Eduardo F. Coleção fortuna crítica: Guimarães Rosa. Rio de Janeiro: Civilização brasileira, 1991, p. 478-490.

HOMERO. Ilíada. Trad.: Carlos Alberto Nunes. Rio de Janeiro: Ediouro, 2001, 572p.

ISER, Wolfgang. "A interação do Texto com o leitor". In: A literatura e o leitor. Seleção e tradução de Luiz Costa Lima. Rio de Janeiro: Paz e Terra, 1979, p. 83132.

ISER, Wolfgang. O ato da leitura. (vol. 1). Trad.: Johannes Kretschmer. São Paulo: Ed. 34, 1996.

ISER, Wolfgang. O ato da leitura. (vol. 2). Trad.: Johannes Kretschmer. São Paulo: Ed. 34, 1999.

JAUSS, Hans Robert. “A Estética da Recepção: Colocações Gerais". In: A literatura e o leitor. Seleção e tradução de Luiz Costa Lima. Rio de Janeiro: Paz e Terra, 1979, p. 43-62.

KAYSER, Wolfgang. Análise e interpretação da obra literária. Trad.: Paulo Quintela. Coimbra: Ed. Almênio Amado, 1985.

KOSELLECK, Reinhart. Futuro Passado: Contribuição à semântica dos tempos históricos. Trad.: Wilma Patrícia Maas, Carlos Almeida Pereira. Rio de Janeiro: Contraponto: Ed. PUC-Rio, 2006, 364p.

LESSING, Gotthold Ephraim. "Laocoonte". in: De teatro e literature. Introdução e notas de Anatol Rosenfeld. São Paulo: Editora Herder, 1964, p. 115 - 130.

MANN, Thomas. A montanha mágica. Trad. Herbert Caro. $2^{\mathrm{a}}$ ed. Rio de Janeiro: Nova Fronteira, 2000.

MARTINS, Nilce Sant'Anna. O Léxico de Guimarães Rosa. São Paulo: Ed. Edusp, 2001 .

MENDILOW, Adam Abraham. O tempo e o Romance. Tradução de Flávio Wolf. Porto Alegre: Globo, 1972, 272p.

MONEGAL, Emir Rodriguez. "Em busca de Guimarães Rosa". In: COUTINHO, Eduardo F. Coleção fortuna crítica: Guimarães Rosa. Rio de Janeiro: Civilização brasileira, 1991, p. 47-61.

MORAIS, Márcia Marques de. "Traições e 'Traição': reticências no Grande Sertão: Veredas". In: Suplemento Literário de Minas: Guimarães Rosa 50 Grande Sertão: Veredas. Ed. Imprensa Oficial do Estado de Minas Gerais, 2006.

NUNES, Benedito. "Literatura e Filosofia: (Grande sertão: veredas)". In: Teoria da literatura em suas fontes. Organização de Luiz Costa Lima. Rio de Janeiro: F. Alvez, 1983, p. 188-207.

NUNES, Benedito. O tempo na narrativa. $2^{\mathrm{a}}$ ed. São Paulo: Ed. Ática, 2002, 84p. 
NUNES, Benedito. "O amor na obra de Guimarães Rosa". In: COUTINHO, Eduardo F. Coleção fortuna crítica: Guimarães Rosa. Rio de Janeiro: Civilização brasileira, 1991, p. 144-169.

Outras margens: estudos da obra de Guimarães Rosa. Org. Lélia Parreira Duarte, Maria Theresa Abelha Alves. Belo Horizonte: Autêntica/PUC Minas, 2001.

PEREZ, Renard. "Guimarães Rosa". In: COUTINHO, Eduardo F. Coleção fortuna crítica: Guimarães Rosa. Rio de Janeiro: Civilização brasileira, 1991, p. 37-46.

PLATÃO. "Fedro" in: Diálogos. Trad. Jorge Paleikat. Rio de Janeiro: Ed. Globo, s/d.

PLOTINO. The enneads. Trad. Stephen Mackenna. London: Penguin Books, 1991.

POUILLON, Jean. O tempo no romance. Tradução de Heloysa de Lima Dantas. São Paulo: Cultrix, Ed. da Universidade de São Paulo, 1974, 201p.

PRESTES, Anita Leocádia. Uma epopeia brasileira: a Coluna Prestes. São Paulo: Moderna, 1995.

PROENÇA, Cavalcanti M. Trilhas no Grande Sertão. Os cadernos de cultura. Ed. Ministério da Educação e Cultura, s/d.

QUINO. Não fui eu! Trad.: Monica Stabel. São Paulo: Martins Fontes, 2003.

REIS, José Carlos. História, a ciência dos homens no tempo. Londrina: EDUEL, 2009, $254 \mathrm{p}$.

RICOEUR, Paul. A memória, a história, o esquecimento. Tradução: Alan François [et al.]. Campinas, SP: Editora da UNICAMP, 2007, 535p.

RICOEUR, Paul. O si-mesmo como um outro. Tradução: Lucy Moreira Cesar. Campinas, SP: Papirus, 1991, 432p.

RICOEUR, Paul. Tempo e narrativa (tomo I). Tradução Constança Marcondes Cesar. Campinas, SP: Papirus, 1994, 327p.

RICOEUR, Paul. Tempo e narrativa (tomo II). Tradução Maria Appenzeller. Campinas, SP: Papirus, 1995, 286p.

RIEDEL, Dirce Côrtes. O tempo no romance machadiano. Rio de Janeiro: Livraria São José, 1959, 223p.

RÓNAI, Paulo. "A arte de contar em Sagarana". In: ROSA, João Guimarães. Sagarana. Rio de Janeiro: Nova Fronteira, 2001, p. 15-21.

RONCARI, Luiz. O Brasil de Rosa. Ed. Unesp, São Paulo, 2004, 348p.

ROSA, João Guimarães. "Carta de João Guimarães Rosa a João Condé, revelando segredos de Sagarana". In: ROSA, João Guimarães. Sagarana. Rio de Janeiro: Nova Fronteira, 2001, p. 23-28. 
ROSA, João Guimarães. Correspondência com seu tradutor alemão Curt MeyerClason: (1958-1967). Org. Maria Apparecida Faria Marcondes Bussolotti; trad. Erlon José Paschoal. Rio de Janeiro: Nova Fronteira: Academia Brasileira de Letras; Belo Horizonte, MG: Ed. da UFMG, 2003.

ROSA, João Guimarães. Correspondência com seu tradutor italiano Edoardo Bizzarri. $3^{\mathrm{a}}$ ed. Rio de Janeiro: Nova Fronteira, 2003.

ROSA, João Gumarães; LORENZ, Günter. "Diálogo com Guimarães Rosa". In: COUTINHO, Eduardo F. Coleção fortuna crítica: Guimarães Rosa. Rio de Janeiro: Civilização brasileira, 1991, p. 62-97.

ROSA, João Guimarães. Grande Sertão: Veredas. Ed. Comemorativa. Rio de Janeiro: Nova Fronteira, 2006.

ROSA, João Guimarães. No Urubuquaquá, no Pinhém. Rio de Janeiro: Nova Fronteira, 2001.

ROSA, João Guimarães. Noites do Sertão. Rio de Janeiro: Nova Fronteira, 2001.

ROSA, João Guimarães. Primeiras Estórias. Rio de Janeiro: Nova Fronteira, 2001.

ROSA, João Guimarães. Sagarana. Rio de Janeiro: Nova Fronteira, 2001.

ROSA, João Guimarães. Tutaméia. Ed. Nova Fronteira, São Paulo, 2001.

ROSENFIELD, Kathrin Holzermayr. Os descaminhos do demo: tradição e ruptura em Grande Sertão: Veredas. Rio de Janeiro: Ed. Imago; São Paulo: EDUSP, 1993, 220p.

SAMPAIO, Teodoro. O rio São Francisco e a Chapada Diamantina. Apud.: Petrônio Braz. In: Gazeta: Norte de Minas, 07-06-2009. Retirado do site em abril de 2011:http:/www.gazetanortemineira.com.br/novogazeta/index.php?option=com _content\&view=article\&id=411:os-jaguncos-de-neco\&catid=24:petroniobraz\&Itemid $=23$.

SANTOS, Paulo de Tarso. O diálogo no Grande Sertão: Veredas. São Paulo: Ed. Hucitec, 1978, 47p.

SCHOPENHAUER, Arthur. Sobre o oficio do escritor. Tradução de Luiz Sérgio Repa; Eduardo Brandão. São Paulo: Martins Fontes, 2003, 205p.

SCHWARZ, Roberto. "Grande Sertão: Estudos". In: COUTINHO, Eduardo F. Coleção fortuna crítica: Guimarães Rosa. Rio de Janeiro: Civilização brasileira, 1991, p. 378-389.

SZONDI, Peter. Teoria do drama moderno [1880-1950]. São Paulo: Cosac \& Naify, 2001, 192p.

SIMÕES, Irene Gilberto. Guimarães Rosa: as paragens mágicas. São Paulo: Ed. Perspectiva, s/d. 
SPINA, Segismundo. A cultura literária medieval. São Paulo: Ed. Ateliê Editorial, 1997.

SPINA, Segismundo. A lírica trovadoresca. São Paulo: Ed. Edusp, 1996.

THOMAS, Henry. Las novelas de caballerías españolas y portuguesas : despertar de la novela. caballeresca. Madrid: Consejo Superior de Investigaciones Científicas, 1952.

VIRGÍLIO. Eneida. Tradução e notas, Odorico Mendes. Cotia, SP: Ateliê Editorial; Campinas, SP: Editora da UNICAMP, 2005, 307p.

WARD, Teresinha Souto. O discurso oral em Grande Sertão: Veredas. São Paulo: Duas Cidades; Brasília: INL, Fundação Nacional Pró-Memória, 1984, 149p.

WEINRICH, Harald. Estructura y función de los tiempos en el lenguaje. Versión española de Federico Latorre. Madrid: Biblioteca Románica Hispánica; Editorial Gredos, 1974, 419p.

\section{Outras Referências:}

ROSA, João Guimarães. Nonada. DVD que acompanha a edição comemorativa dos 50 anos de Grande Sertão: Veredas com entrevistas sobre a vida e a obra do autor.

ROSA, João Guimarães. Grande Sertão: Veredas. Rio de Janeiro: Ed. Nova Fronteira, 2006. Edição Biblioteca do Estudante em formato PDF disponibilizada pela editora em comemoração aos 50 anos de Grande Sertão: Veredas, 608p. 